Structure-function analysis of $\mathrm{CNF}_{Y}$

\title{
Crystal structure of full-length cytotoxic necrotizing factor CNFy reveals molecular building blocks for intoxication
}

Paweena Chaoprasid ${ }^{1,2^{*}}$, Peer Lukat ${ }^{3^{*}}$, Sabrina Mühlen ${ }^{1,2,4^{*}}$, Thomas Heidler ${ }^{5}$, EmerichMihai Gazdag ${ }^{3}$, Shuangshuang Dong ${ }^{3}$, Wenjie $\mathrm{Bi}^{6}$, Christian Rüter $^{1}$, Marco Kirchenwitz ${ }^{7}$, Anika Steffen 7 , Lothar Jänsch ${ }^{6,8}$, Theresia E. B. Stradal ${ }^{7,8}$, Petra Dersch ${ }^{1,2,4,9 \#}$ \& Wulf Blankenfeldt ${ }^{3,10 \#}$

${ }^{1}$ Institute of Infectiology, Center for Molecular Biology of Inflammation (ZMBE), University of Münster, Von-Esmarch-Straße 56, 48149 Münster, Germany

${ }^{2}$ Molecular Infection Biology, Helmholtz Centre for Infection Research, Inhoffenstr. 7, 38124 Braunschweig, Germany

${ }^{3}$ Structure and Function of Proteins, Helmholtz Centre for Infection Research, Inhoffenstr. 7, 38124 Braunschweig, Germany

${ }^{4}$ Deutsches Zentrum für Infektionsforschung, Inhoffenstr. 7, 38124 Braunschweig

${ }^{5}$ Molecular Structural Biology, Helmholtz Centre for Infection Research, Inhoffenstr. 7, 38124 Braunschweig, Germany

${ }^{6}$ Cellular Proteomics, Helmholtz Centre for Infection Research, Inhoffenstr. 7, 38124 Braunschweig, Germany

${ }^{7}$ Cell Biology, Helmholtz Centre for Infection Research, Inhoffenstr. 7, 38124 Braunschweig, Germany

${ }^{8}$ Institute of Zoology, Technische Universität Braunschweig, Spielmannstr. 7, 38106 Braunschweig, Germany

${ }^{9}$ Institute of Microbiology, Technische Universität Braunschweig, Spielmannstr. 7, 38106 Braunschweig, Germany

${ }^{10}$ Institute for Biochemistry, Biotechnology and Bioinformatics, Technische Universität Braunschweig, Spielmannstr. 7, 38106 Braunschweig, Germany

*equal contribution

"corresponding authors 
bioRxiv preprint doi: https://doi.org/10.1101/2020.04.07.029181; this version posted September 21, 2020. The copyright holder for this preprint (which was not certified by peer review) is the author/funder, who has granted bioRxiv a license to display the preprint in perpetuity. It is made available under aCC-BY-NC-ND 4.0 International license.

Structure-function analysis of $\mathrm{CNF}_{\mathrm{Y}}$

\section{Abstract}

Cytotoxic necrotizing factors (CNFs) are bacterial single-chain exotoxins that modulate cytokinetic/oncogenic and inflammatory processes through activation of host cell Rho GTPases. To achieve this, they are secreted, bind surface receptors to induce endocytosis and translocate a catalytic unit into the cytosol to intoxicate host cells. A three-dimensional structure that provides insight into the underlying mechanisms is still lacking. Here, we determined the crystal structure of full-length Yersinia pseudotuberculosis $\mathrm{CNF}_{\mathrm{Y}}$. CNFY consists of five domains (D1-D5), and by integrating structural and functional data we demonstrate that D1-3 act as export and translocation module for the catalytic unit (D4-5) or fused $\beta$-lactamase reporter proteins. We further found that domain D4, which possesses structural similarity to ADP-ribosyl transferases, but had no equivalent catalytic activity, changed its position to interact extensively with D5 in the crystal structure of the free D4-5 fragment. This liberates D5 from a semi-blocked conformation in full-length $\mathrm{CNF}_{\mathrm{Y}}$, leading to higher deamidation activity. Finally, sequence comparisons identified the CNF translocation module in many uncharacterized bacterial proteins, suggesting its usability as a universal drug delivery tool. 
bioRxiv preprint doi: https://doi.org/10.1101/2020.04.07.029181; this version posted September 21, 2020. The copyright holder for this preprint (which was not certified by peer review) is the author/funder, who has granted bioRxiv a license to display the preprint in perpetuity. It is made available under aCC-BY-NC-ND 4.0 International license.

Structure-function analysis of $\mathrm{CNF}_{\mathrm{Y}}$

\section{Introduction}

Amongst the plethora of traits developed by pathogenic bacteria to establish infections, toxins play the most prominent role, since they are responsible for the majority of clinical symptoms (Popoff, 2005). Many bacterial exotoxins are key virulence factors that target different functions of host cells to break barriers, improve access to nutrients, defeat immune responses and promote bacterial dissemination within and among hosts.

The cytotoxic necrotizing factors (CNFs) belong to a class of bacterial exotoxins that deamidate a glutamine (Q61 or Q63) in the active site (switch II region) of host cell proteins belonging to the small Rho GTPase family, i.e. RhoA, Rac1 and Cdc42 (Flatau et al, 1997; Schmidt et al, 1997; Knust \& Schmidt, 2010). This locks these key regulators in their active state, causing a multitude of downstream effects that are most readily observed as alterations of the actin cytoskeleton or perturbations of other cellular processes including phagocytosis, cell proliferation (multinucleation), reactive oxygen species production, and the release of anti-apoptotic and pro-inflammatory factors (Fabbri et al, 2013; Hodge \& Ridley, 2016; Ho et al, 2018). The consequences of these effects are changes of innate immune responses and tissue damage, leading to the development of acute disease symptoms (Knust \& Schmidt, 2010; Schweer et al, 2013; Diabate et al, 2015; Cavaillon, 2018; Heine et al, 2018).

CNFs are found in several pathogenic bacteria, predominantly in pathogenic Escherichia coli, but also in Yersinia pseudotuberculosis, Shigella species, Salmonella enterica, as well as in Moritella viscosa and Photobacterium damselae, pathogens of economically important fish (Fig EV1) (Morgan et al, 2019). In addition, CNFs show local homology to other toxins such as the dermonecrotizing toxin DNT of Bordetella pertussis and the PMT toxin of Pasteurella multocida (Walker \& Weiss, 1994), indicating that these proteins consist of common structural building blocks that have been interchanged in the course of evolution.

CNF1, the most thoroughly investigated representative of the CNF family, is a major virulence factor in uropathogenic E. coli (UPEC) strains, which live in the intestine and enter the urinary tract via the urethra (Boquet, 2001; Knust \& Schmidt, 2010; Ho et al, 2018). 
bioRxiv preprint doi: https://doi.org/10.1101/2020.04.07.029181; this version posted September 21, 2020. The copyright holder for this preprint (which was not certified by peer review) is the author/funder, who has granted bioRxiv a license to display the preprint in perpetuity. It is made available under aCC-BY-NC-ND 4.0 International license.

Structure-function analysis of $\mathrm{CNF}_{\mathrm{Y}}$

CNF1-containing strains exhibit a higher viability, have a higher potential to colonize the urinary tract, affect the function of immune cells and increase the inflammation rate (Falzano et al, 1993; Fournout et al, 2000; Rippere-Lampe et al, 2001). CNF1 was also identified in some intestinal and extraintestinal E. coli (ExPEC) where it was found to increase bacterial invasion into endothelial cells (Khan et al, 2002) and to promote malignant tumor conversion and intestinal cell invasiveness (Zhang et al, 2018; Fabbri et al, 2019). Similarly, the homologous toxin $\mathrm{CNF}_{\mathrm{Y}}$, which shares $65 \%$ identity with $E$. coli CNF1, is crucial for the pathogenicity of Y. pseudotuberculosis, which causes food-borne and zoonotic enteric infections that manifest themselves as enteritis, mesenterial lymphadenitis and more rarely, in sequelae such as reactive arthritis (Koornhof et al, 1999a; Smego et al, 1999; Heine et al, 2018). The importance of CNFY is emphasized by the fact that a knock-out mutation of the $c n f Y$ gene leads to avirulence, allowing bacteria to become persistent in mice (Heine et al, 2018). Recent studies demonstrated that Rho GTPase activation by CNFy enhances the translocation of Yersinia outer proteins (Yops) into neutrophils and macrophages via a type III secretion system (T3SS). This blocks phagocytosis, triggers immune cell death and contributes to massive tissue damage by induction of pro-inflammatory responses and necrosis (Schweer et al, 2013; Wolters et al, 2013).

CNFs may also hold promise for treatment of neurological disorders and cancer (Maroccia et al, 2018). For example, CNF1 injection into brains of mice enhanced neurotransmission and synaptic plasticity, leading to improved learning and memory (Diana et al, 2007). Moreover, CNF1 was able to rescue wildtype-like mitochondrial morphology in fibroblasts derived from patients with myoclonic epilepsy, and it reduced tumor growth (Vannini et al, 2016; Fabbri et al, 2018). As CNFs efficiently intoxicate a broad range of host cells, transport modules of the toxin may also be useful for drug delivery (Haywood et al, 2018). To exploit and further develop this tool, detailed knowledge of the molecular mechanisms underlying CNF secretion, translocation and activity is required. However, little is known about the global structure and the individual functional units of CNFs and so far, only the structure of the catalytic domain of CNF1 has been determined (Buetow et al, 2002). 
bioRxiv preprint doi: https://doi.org/10.1101/2020.04.07.029181; this version posted September 21, 2020. The copyright holder for this preprint (which was not certified by peer review) is the author/funder, who has granted bioRxiv a license to display the preprint in perpetuity. It is made available under aCC-BY-NC-ND 4.0 International license.

Structure-function analysis of $\mathrm{CNF}_{\mathrm{Y}}$

At the sequence level, CNF-type toxins of different species share at least $55 \%$ overall identity (Fig EV1), indicating similar structures and conserved modes-of-action, although they show differential preferences with respect to the targeted Rho GTPase and interact with different host cell receptors (Hoffmann et al, 2004; Blumenthal et al, 2007). CNF1 uses two cellular receptors to enter host cells, the 37-kDa laminin receptor precursor p37LRP, which is recognized by sequences located within the $\mathrm{N}$-terminus of the toxin, and the Lutheran adhesion glycoprotein/basal cell adhesion molecule (Lu/BCAM), which interacts with motifs in the C-terminal half (Fabbri et al, 1999; Chung et al, 2003; Kim et al, 2005; McNichol et al, 2007; Piteau et al, 2014; Reppin et al, 2017). The receptor of the N-terminal part of CNFY is still unknown, but it has been shown that binding of CNF1 to host cells has no effect on CNFy uptake (Blumenthal et al, 2007), suggesting that both toxins use different host cell factors to enter host cells. This has also been corroborated in a recent study that identified glycosaminoglycans as interaction partners of C-terminal fragments of $\mathrm{CNF}_{\mathrm{Y}}$ (Kowarschik et al, 2020). The CNFs are taken up into endosomes and their release into the host cytoplasm requires two hydrophobic sequence motifs within the $\mathrm{N}$-terminal half of the toxin that have been predicted to form a-helices. These helices are separated by a loop containing an acidic patch of four conserved acidic amino acids, and they are believed to insert into the endosomal membrane upon charge neutralization of the patch in the course of endosome acidification (Pei et al, 2001). An unidentified protease then cleaves CNF (i.e. CNF1 between residues 532 and 544), and the C-terminal fragment including the catalytic domain (residues 720-1014) is released into the cytosol of the host cell to mediate the cellular effects of the toxin (Pei et al, 2001; Knust et al, 2009).

In this study, we resolved the crystal structure of the full-length $Y$. pseudotuberculosis $\mathrm{CNF}_{\mathrm{Y}}$ protein, necessary to achieve an understanding of its transport and functional mechanisms and its potential therapeutic use. The $\mathrm{CNF}_{Y}$ structure revealed a complex setup of five individual building blocks and allowed us to obtain detailed information about the minimal secretion and translocation domain required to transport the catalytic domain or a fused cargo protein into the host cell cytosol, which could be exploited for drug delivery. 
Structure-function analysis of $\mathrm{CNF}_{Y}$

\section{Results}

\section{CNFy contains five structural building blocks}

Recombinant full-length $\mathrm{CNF}_{\mathrm{Y}}$ was produced in E. coli (Appendix Fig S1) and crystallized in space group $12,2,21$. These crystals diffracted to $2.7 \AA$ and contained one CNFY molecule in the asymmetric unit. Since no suitable search model for molecular replacement was available and crystallization of full-length seleno- $L$-methionine-labelled protein failed, we also crystallized different fragments of CNFy: (i) one containing only the deamidase domain (residues 720-1014), (ii) another consisting of the subunit which is likely released into the cytosol (residues 526-1014) based on the homology to E. coli CNF1 (Hoffmann et al, 2004; Blumenthal et al, 2007), and (iii) a third fragment including the complete N-terminal portion with parts of the released subunit (residues 1-704) (Appendix Fig S1). A detailed description of structure determination by Se-SAD and molecular replacement is given in the Materials and Methods section and an overview over data collection and refinement statistics as well as the respective Protein Data Bank (Berman et al, 2000) deposition codes is provided in Table EV1.

$\mathrm{CNF}_{\mathrm{Y}}$ adopts a compact, modular structure of five structural building blocks (D1-D5) with approximate dimensions of $115^{\star} 73^{\star} 65 \AA$ (Fig 1A-C). All residues of the protein could be traced in the structure of the holo-protein with the exception of residues N430-K431, S550L553 and P701-L717. The unresolved amino acids resided in surface loops, indicating intrinsic flexibility. Analysis with PiSQRD (Aleksiev et al, 2009) assigns domain boundaries to residues 1-22/135-424 (D1), 23-134 (D2), 425-529 (D3), 530-700 (D4) and 718-1014 (D5, deamidase domain). The compact arrangement of D1-D5 in the full-length structure of $\mathrm{CNF}_{\mathrm{Y}}$ prompted us to investigate the interactions between the five individual domains of $\mathrm{CNF}_{Y}$ in more detail. Analysis with PISA (Krissinel \& Henrick, 2007) reveals large hydrophobic interfaces between D1 and D2 (interface area $870 \AA^{2}$ ) as well as between D3 and D4 (750 $\left.\AA^{2}\right)$ (Appendix Tab S1). The C-terminal domain D5 interacts mainly with D3 $\left(610 \AA^{2}\right)$, which, as a consequence, partially blocks the entrance to the catalytic site. D5 
Structure-function analysis of $\mathrm{CNF}_{Y}$

interacts only weakly with D4 $\left(380 \AA^{2}\right)$, which itself establishes an extensive interface with D1 $\left(1390 \AA^{2}\right)($ Fig 1C).

The crystal structure of the fragment comprising residues 1-704 (D1-D4) is fully superimposable with the respective residues of the holo-protein. The isolated D4-D5 fragment, on the other hand, showed a different orientation of the two domains with respect to the fulllength protein and was thus included into the following more detailed structure-functional analysis together with full-length $\mathrm{CNF}_{\mathrm{Y}}$.

\section{Structural analysis and structure-guided mutagenesis provide insight into the function of the structural building blocks of $\mathrm{CNF}_{\mathrm{Y}}$}

In order to gain insights into the biological function of the individual building blocks, we performed a detailed structural analysis of the full-length $\mathrm{CNF}_{\mathrm{Y}}$ (D1-D5) and constructed truncated, mutated and marker-tagged versions of $\mathrm{CNF}_{Y}$ to investigate their secretion, translocation and enzymatic activity in human epithelial cells. The truncations were designed to interrupt the protein within linker regions between the individual domains (Fig 2A). $\mathrm{CNF}_{\mathrm{Y}}$ variants were produced in $Y$. pseudotuberculosis or as recombinant proteins from E. coli (Fig 2B, Appendix Fig S1). Their enzymatic activity was tested with bacterial extracts or purified proteins by assessing their ability to deamidate RhoA in intact HEp-2 cells and host cell extracts, and by assessing the induction of actin rearrangements and the inhibition of cell division (formation of multinuclear cells) (Fig 3). The ability to bind to host cells was tested with 3xFlag-tagged versions of the $\mathrm{CNF}_{Y}$ derivatives (Figs 2D), and their capacity to reach late endosomes was measured with $\mathrm{CNF}_{Y}$-GFP fusion variants (Fig 4). $\mathrm{CNF}_{\mathrm{Y}}$ export from the bacterial cell and cytosolic translocation of the $\mathrm{CNF}_{\mathrm{Y}}$ activity domain were detected with $\mathrm{CNF}_{\mathrm{Y}-\beta} \beta$-lactamase (TEM) constructs (Figs $2 \mathrm{C}, 3 \mathrm{~A}$ ). Secretion of the CNFY-TEM derivatives was analyzed by incubation of bacterial culture supernatants with nitrocefin, a chromogenic cephalosporin substrate used to detect $\beta$-lactamases. Translocation of the CNFY-TEM fusion proteins was detected by staining the cytosol of host cells with the FRET substrate CCF4-AM, which contains the coumarin- and fluorescein- 
bioRxiv preprint doi: https://doi.org/10.1101/2020.04.07.029181; this version posted September 21, 2020. The copyright holder for this preprint (which was not certified by peer review) is the author/funder, who has granted bioRxiv a license to display the preprint in perpetuity. It is made available under aCC-BY-NC-ND 4.0 International license.

Structure-function analysis of $\mathrm{CNF}_{\mathrm{Y}}$

conjugated $\beta$-lactam cephalosporin and is green fluorescent (excitation at $409 \mathrm{~nm}$, emission at $530 \mathrm{~nm}$ ). Cleavage of the $\beta$-lactam ring shifts the fluorescence of the compound to blue (emission at $450 \mathrm{~nm}$ ) and thus indicates the presence of TEM $\beta$-lactamase in the cytosol.

For validation, we first tested marker-tagged full-length wildtype $\mathrm{CNF}_{Y}\left(\mathrm{CNF}_{Y}\right.$ 1-1014) and a mutant derivative, namely CNFY C866S. This substitution inactivated the deamidase activity when introduced into E. coli CNF1 (Hoffmann et al, 2004). The marker-tagged versions of the full-length $\mathrm{CNF}_{Y}$ wildtype protein were efficiently produced (Fig. 2B), secreted (Fig 2C), and internalized into host cells (Fig 2D). Inside cells they were targeted to the late endosome (Fig 4) and translocated into the host cell cytosol (Fig 3A) to deamidate RhoA (Fig 3B) and induce formation of stress fibers or polynucleation in cultured cells (Fig 3C). In contrast, all $\mathrm{CNF}_{\mathrm{Y}} \mathrm{C} 866 \mathrm{~S}$ derivatives were found to abrogate the RhoA deamidation and induction of multinucleated cells, whereas other properties were not affected (Fig 2BD, 3). Together, this demonstrates the suitability of the employed test systems.

\section{Domain D1 is a major component of the translocation apparatus in CNFS}

The crystal structure of $\mathrm{CNF}_{Y}$ revealed that domain $\mathrm{D} 1$ consists of separate areas covering residues 1-22 and 135-424, which together form a bundle of $\alpha$-helices flanked by a fourstranded anti-parallel $\beta$-sheet that is covered with three $\alpha$-helices from the other side (Fig 1B, Fig EV2). Sequences within domain D1 have previously been shown to contain elements that are required for translocation of the catalytic fragment of E. coli CNF1 (Pei et al, 2001; Knust et al, 2009), suggesting that this domain is a major component of the translocation machinery of CNFs.

Although domain $\mathrm{D} 1$ of $\mathrm{CNF}_{\mathrm{Y}}$ is, due to its overall $\alpha$-helical character, reminiscent of the translocation domain of other toxins such as diphtheria toxin (DT), searches with DALI (Holm \& Rosenström, 2010) detected no significant structural homology to these proteins. Instead, it identified only the segment containing the four-stranded anti-parallel $\beta$-sheet (residues 152-343) as being somewhat similar to a fragment of the translocation domain of nigritoxin, a toxin of crustaceans and insects (PDB entry 5M41; 177 residues aligned, rmsd 
bioRxiv preprint doi: https://doi.org/10.1101/2020.04.07.029181; this version posted September 21, 2020. The copyright holder for this preprint (which was not certified by peer review) is the author/funder, who has granted bioRxiv a license to display the preprint in perpetuity. It is made available under aCC-BY-NC-ND 4.0 International license.

Structure-function analysis of $\mathrm{CNF}_{\mathrm{Y}}$

3.8 $\AA$, 11\% sequence identity) (Fig 5A) (Labreuche et al, 2017). However, the translocation domain of nigritoxin is significantly smaller than the D1 domain of $\mathrm{CNF}_{\mathrm{Y}}$ and does not contain hydrophobic sequence motifs that have previously been predicted to be essential for translocation in CNFs and other toxins (Pei et al, 2001; Orrell et al, 2017), hinting at distinct translocation mechanisms.

To gain further insight into the function of $\mathrm{D} 1$, we constructed marker-tagged $\mathrm{CNF}_{\mathrm{Y}}$ derivatives different deletions within the domain ( $\Delta 39-134, \Delta 134-426, \Delta 39-426$; Fig $2 A)$. The $C N F y \Delta 134-426$ derivative was less efficiently produced and inactive (i.e. it did not deamidate RhoA in host cell extracts, Fig $2 \mathrm{~B}$ and $3 \mathrm{~B}$ ), indicating that it is improperly folded and less stable. However, the $\mathrm{CNF}_{Y} \Delta 39-134$ and $\mathrm{CNF}_{Y} \Delta 39-426$ proteins were well expressed and enzymatically active, yet, they failed to be secreted (Fig 2B-C), and consequently unable to trigger RhoA activation when added to host cells (Fig 3B). On the other hand, a C-terminally truncated CNFy protein containing the entire domain D1 (1-443) was secreted efficiently (Fig $2 \mathrm{C}$ ), corroborating that this segment is necessary and sufficient for $\mathrm{CNF}_{\mathrm{Y}}$ to exit the bacterial cell.

Use of $\mathrm{CNF}_{\mathrm{Y}}$-TEM derivatives further revealed that all deletions of or within domain $\mathrm{D} 1$ abolished translocation of the active domain into the host cell cytoplasm when added to host cells (Fig $3 \mathrm{~A}$ ), although $\mathrm{CNF}_{\mathrm{Y}} \Delta 39-134$ and $\mathrm{CNF}_{\mathrm{Y}} \Delta 39-426$ derivatives were still able to bind and enter cells (Fig 2D), and associate with the late endosome (Fig 4). This demonstrated that domain D1 is an important component of the translocation machinery but not essential for host cell binding and endocytosis.

For E. coli CNF1, two hydrophobic $\alpha$-helices have been predicted between residues 350 372 and 387-412, which are believed to insert into the endosomal membrane after charge neutralization of a conserved acidic patch in the connecting loop (D373, D379, E382 and E383) (Pei et al, 2001). However, the respective segments do not fold into the predicted $\alpha$ helices in $\mathrm{CNF}_{\mathrm{Y}}$ but adopt mostly loop-like structures with a helical part at their $\mathrm{C}$-terminus (Fig 1B, Fig EV2), which may be a consequence of the neutral $\mathrm{pH}$ at which $\mathrm{CNF}_{\mathrm{Y}}$ has been crystallized here. In line with previous work on E. coli CNF1, site-directed mutagenesis of 
bioRxiv preprint doi: https://doi.org/10.1101/2020.04.07.029181; this version posted September 21, 2020. The copyright holder for this preprint (which was not certified by peer review) is the author/funder, who has granted bioRxiv a license to display the preprint in perpetuity. It is made available under aCC-BY-NC-ND 4.0 International license.

Structure-function analysis of $\mathrm{CNF}_{\mathrm{Y}}$

the acidic residues E382 and E383 in the acidic patch to lysines did not abolish the enzymatic activity of the toxin derivative when added to cell lysates (Appendix Fig. S2). The CNFY E382K/E383K variant was still secreted and able to enter cells but failed to activate RhoA and induce multinucleation (Appendix Fig S2). This supported previous assumptions that acidic residues in the connecting loop are important for translocation (Pei et al, 2001).

Importantly, domain D1 alone does not seem to be sufficient for the translocation process, as the C-terminally truncated derivative $\mathrm{CNF}_{\mathrm{Y}} 1-443$, consisting of domains $\mathrm{D} 1$ D2, was unable to translocate the $\beta$-lactamase TEM cargo protein into the cytosol, deamidate RhoA in host cells and induce multinucleation (Fig 3), despite the fact that it was internalized and reached late endosomes (Fig 4). This indicated that the translocation machinery of CNFs requires additional components for functionality.

\section{Domain $D 2$ is a receptor binding domain of CNFs}

Unlike the N-terminal a-helix (residues 5-18), which is an integral part of the helical bundle that dominates domain $D 1$, residues $23-134$ seem to establish a separate structural building block (domain D2) that protrudes from the mostly $\alpha$-helical subunit, potentially suggesting its insertion during evolution (Fig 1B). It consists of a three-stranded anti-parallel $\beta$-sheet flanked by a-helices at the side facing D1 and by several surface-exposed loops at the other. One solvent-exposed loop contains residues 53-75, a segment that has previously been implicated in host cell binding of E. coli CNF1 to receptor p37LRP/LR67 (Fig 1B, Fig EV2) (Fabbri et al, 1999; Chung et al, 2003; Kim et al, 2005). It is hence conceivable that this domain represents the N-terminal receptor binding domain of CNFs. The solventexposed loop interacts with residues 112 to 116 at the surface of D2, such that these segments together may establish a receptor-binding interface of the CNFs (Fig EV2). There are ten amino acid changes between CNF1 and CNFY within these regions (Fig EV1), which may account for the distinct receptor specificity of both toxins (Blumenthal et al, 2007).

As outlined above, host cell binding and colocalization studies with truncated $\mathrm{CNF}_{Y}$ derivatives showed that the D1-2 (1-443) fragment was able to bind host cells (Fig 2D) and 
bioRxiv preprint doi: https://doi.org/10.1101/2020.04.07.029181; this version posted September 21, 2020. The copyright holder for this preprint (which was not certified by peer review) is the author/funder, who has granted bioRxiv a license to display the preprint in perpetuity. It is made available under aCC-BY-NC-ND 4.0 International license.

Structure-function analysis of $\mathrm{CNF}_{\mathrm{Y}}$

reached the late endosomes (Fig 4), indicating that this truncated version of $\mathrm{CNF}_{\mathrm{Y}}$ indeed includes a cell receptor binding site similar to CNF1 (Fabbri et al, 1999; Chung et al, 2003; Kim et al, 2005). However, this also demonstrates that $\mathrm{CNF}_{Y}$, unlike previous work with CNF1 suggests (Piteau et al, 2014; Reppin et al, 2017), does not require a second recognition site in the C-terminal region to enter host cells.

Domain D3 is an essential part of the translocation apparatus of CNFs:

The third domain, D3 (residues 425-529), is reminiscent of an incomplete $\beta$-barrel, containing six anti-parallel strands in CNFy. No homologous structures could be discovered with DALI. Because a fragment consisting only of domains $\mathrm{D} 1-2\left(\mathrm{CNF}_{\mathrm{Y}} 1-443\right)$ was not able to translocate the fused TEM- $\beta$-lactamase into the host cell cytosol whereas the D1-3 fragment ( $\mathrm{CNF}_{\mathrm{Y}}$ 1-526) was (Fig 3A), D3 is obviously essential for intoxication. D1-3 translocated TEM- $\beta$-lactamase with the same efficiency as full-length $\mathrm{CNF}_{\mathrm{Y}}$ (Appendix Fig. S3), and although it is unclear whether $\beta$-lactamase was released from D1-3 or only exposed on the cytosolic side from the endosomal membrane, these experiments clearly demonstrated that the translocation apparatus of CNFs consists of the three domains D13. The importance of D3 is also highlighted by the fact that (i) the N-terminus of Pasteurella multocida exotoxin PMT possesses high homology to $\mathrm{D} 1-3$ of $\mathrm{CNF}_{\mathrm{Y}}$, whereby cargo delivery includes proteolytic cleavage downstream of the prospective D3 domain, and (ii) the finding that a hybrid toxin consisting of this N-terminal fragment (residues 1-505) of PMT and the ADP-ribosylating domain of DT was able to intoxicate cells (Bergmann et al, 2013; Clemons et al, 2018).

The cleavage site between D3 and D4 is partially shielded in full-length $C N F_{Y}$

The imperfect $\beta$-barrel domain D3 and the following domain D4 are connected via a linker that is partially shielded by the C-terminal deamidase domain D5 in the structure of fulllength $\mathrm{CNF}_{\mathrm{Y}}$ (Fig 1C). In CNF1, this linker is cleaved between residues 532-544 to release the D4-5 subunit into the host cell cytosol (Knust et al, 2009), suggesting that the respective 
bioRxiv preprint doi: https://doi.org/10.1101/2020.04.07.029181; this version posted September 21, 2020. The copyright holder for this preprint (which was not certified by peer review) is the author/funder, who has granted bioRxiv a license to display the preprint in perpetuity. It is made available under aCC-BY-NC-ND 4.0 International license.

Structure-function analysis of $\mathrm{CNF}_{\mathrm{Y}}$

segment must become solvent-exposed in the course of host cell intoxication to be accessible to proteases. As outlined below, this likely is linked to unfolding during translocation of the D4-5 segment into the cytosol of the host cell.

In order to identify amino acids that are important for the cleavage step, we introduced mutations within this linker. All recombinant mutant proteins were able to bind to host cells and deamidate RhoA in cell lysates, indicating proper folding and full activity (Fig 6). Interestingly, the CNFY 1535L/P536A/V537G mutant with changes in the N-terminal part of the linker ( $\mathrm{CNF}_{\mathrm{Y}}$ mut1) promoted translocation into the host cell cytoplasm and was able to deamidate RhoA when added to host cells (Fig 6). However, this was not the case for the $\mathrm{CNF}_{\mathrm{Y}}$ variant $1535 \mathrm{~L} / \mathrm{P} 536 \mathrm{~A} / \mathrm{V} 537 \mathrm{G} / \mathrm{F5} 59 \mathrm{~L} / \mathrm{D} 541 \mathrm{~A} / \mathrm{K} 542 \mathrm{~A}$ (Fig 6), suggesting that this variant is unable to escape the endosome. In summary, this indicated that amino acids important for proper processing are located at the C-terminal end of the linker.

\section{Domain D4 has structural similarity to ADP-ribosyl transferases}

Sequence analysis places the fourth domain D4 (residues 530-700) into the DUF4765 family, a building block that is also found in a number of other uncharacterized bacterial proteins (Fig EV3A). Surprisingly, structure similarity searches reveal distant but significant homology to ADP-ribosyl transferase (ART) domains (Appendix Tab S2), which are widespread in protein toxins (Fieldhouse \& Merrill, 2008). This similarity is exemplified by two examples (Clostridium perfringens iota toxin, PDB entry 4H03 (Tsurumura et al, 2013); Pseudomonas aeruginosa ExoA, PDB entry 2ZIT (Jørgensen et al, 2008)) shown in Fig 5B and Fig EV3.

In order to gain further insight into the function of domain D4, which is translocated and released together with the catalytic domain, we analyzed two mutant variants harboring internal deletions of amino acids 527-719 or 527-699. However, both variants did not deamidate RhoA in host cell lysates, indicating that these mutant proteins failed to fold properly (Appendix Fig S4). Since structure similarity searches revealed distant homology to the ADP-ribosyltransferase (ART) domains, we hypothesized that CNFs may possess a 
bioRxiv preprint doi: https://doi.org/10.1101/2020.04.07.029181; this version posted September 21, 2020. The copyright holder for this preprint (which was not certified by peer review) is the author/funder, who has granted bioRxiv a license to display the preprint in perpetuity. It is made available under aCC-BY-NC-ND 4.0 International license.

Structure-function analysis of $\mathrm{CNF}_{\mathrm{Y}}$

second, previously unrecognized enzymatic function encoded in D4. The active sites of ARTs fall into two groups, the RSE- for a conserved arginine-serine-glutamate active site motif and the HYE-ARTs for histidine-tyrosine-glutamate (Cohen \& Chang, 2018). The ARTlike domain D4 contains arginine, glutamate and histidine at the respective positions instead (R599, E639, H676), which could, in principle, support similar chemistry and are, with the exception of the CNF-specific H676, highly conserved in other DUF4765-containing proteins (Fig EV3A). However, exchange of $\mathrm{CNF}_{\mathrm{Y}}$ E639, which is in the comparable position of the conserved glutamate of bacterial ARTs, to alanine or glutamine had no effect on $\mathrm{CNF}_{\mathrm{Y}}$ function (Appendix Fig S5). Moreover, we could not detect binding of the ART cosubstrate $\mathrm{NAD}^{+}$to a $\mathrm{CNF}_{\mathrm{Y}}$ fragment consisting of domains $\mathrm{D} 4-5$ in microscalar thermophoresis titration experiments. The inability to bind $\mathrm{NAD}^{+}$may be a consequence of the altered geometry of the potential $\mathrm{NAD}^{+}$binding site of $\mathrm{D} 4$, which leads to a shallower hypothetical $\mathrm{NAD}^{+}$binding site and to clashes when $\mathrm{NAD}^{+}$is superimposed from the two examples mentioned above (Fig EV3B).

Domain D5 is highly similar to the deamidase domain of CNF1

The C-terminal catalytic deamidase domain D5 is linked to D4 via the unstructured residues P701-L717 (Fig 1B). These belong to the postulated binding epitope for the Lu/BCAM host receptor of CNF1 (Piteau et al, 2014), and their flexibility may be a requirement for receptor binding by the toxin.

The D5 domain is very similar to the respective domain of E. coli CNF1 (PDB entry 1HQ0 (Buetow et al, 2001); $1.8 \AA$ rmsd over 295 residues, 59\% sequence identity), featuring a central $\beta$-sandwich with shielding $\alpha$-helices on both sides (Figs 1B and 5 C). The active site employs the conserved cysteine/histidine couple C866/H881 (Hoffmann et al, 2004), which lies in a crevice on the surface of the domain and deamidates a conserved glutamine in the switch-II region of the targeted Rho GTPases. In agreement, only the full length $\mathrm{CNF}_{\mathrm{Y}}$ protein was able to activate the Rho GTPase RhoA (Fig 3B), resulting in the induction of polynucleation in living cells (Fig $3 \mathrm{C}$ ), whereas all protein variants with deletions of the C- 
bioRxiv preprint doi: https://doi.org/10.1101/2020.04.07.029181; this version posted September 21, 2020. The copyright holder for this preprint (which was not certified by peer review) is the author/funder, who has granted bioRxiv a license to display the preprint in perpetuity. It is made available under aCC-BY-NC-ND 4.0 International license.

Structure-function analysis of $\mathrm{CNF}_{\mathrm{Y}}$

terminal domain D5 eliminated toxicity (Figs 3B-C). This is consistent with studies showing that the C-terminal 300 amino acids (709-1014) of the related E. coli CNF1 protein are important for its activity (Koornhof et al, 1999b; Zhang et al, 2018; Fabbri et al, 2019). Neither the deletion nor site-directed mutagenesis of the catalytic domain affected secretion, host-cell binding, or protein translocation (Figs 2B-C and $3 \mathrm{~A}$ ), indicating that the sole role of the C-terminal domain is the targeting and modification of Rho GTPases.

While the crevice is nearly identical between $\mathrm{CNF}_{\mathrm{Y}}$ and $\mathrm{CNF1}$, differences exist between two loops at the periphery of the active site, namely residues $961-970$ and residues 9961004 (Fig 5C, Fig EV1). It is not clear if these deviations are sufficient to explain the slightly altered preferences for various Rho GTPases that have been described for both CNFs (Hoffmann et al, 2004; Schweer et al, 2013), but amino acids in one of these loops (residues 961-970) has previously been implicated in substrate recognition of CNFY and CNF1 (Hoffmann et al, 2007). Interestingly, a similar deamidation domain is also found in Burkholderia lethal factor 1 (BLF1), despite extremely low sequence similarity (Fig 5C; PDB entry 3TU8; (Cruz-Migoni et al, 2011); 3.5 Å rmsd over 169 residues, 7\% sequence identity). BLF1 is a single-domain toxin that deamidates a glutamine residue in translation initiation factor elF4A. In addition, several other toxins including e.g. Bordetella pertussis dermonecrotizing toxin DNT are predicted to contain similar deamidase domains (Ho et al, 2018).

The D4-5 fragment of $C N F_{Y}$ contains a receptor binding site sufficient for endosomal uptake We further characterized the properties of the recombinant D4-5 domains (residues 5261014), which together constitute the C-terminal fragment that is translocated into the host cell cytoplasm after cleavage of $\mathrm{CNF}_{\mathrm{Y}}$ (Fig EV4). Although catalytically active when added to host cell extracts, D4-5 is unable to deamidate RhoA when added to host cells (Fig EV4ED). This suggested that it was either not taken up into the host cell or unable to escape the endosome to reach the cytoplasm. Cell binding assays demonstrated, however, that the D4-5 fragment ( $\left.C N F_{Y} 526-1014\right)$, similar to $D 1-3\left(C N F_{Y} 1-526\right)$, specifically interacts with 
bioRxiv preprint doi: https://doi.org/10.1101/2020.04.07.029181; this version posted September 21, 2020. The copyright holder for this preprint (which was not certified by peer review) is the author/funder, who has granted bioRxiv a license to display the preprint in perpetuity. It is made available under aCC-BY-NC-ND 4.0 International license.

Structure-function analysis of $\mathrm{CNF}_{\mathrm{Y}}$

host cells (Fig 2D, Fig EV4C and S6). A parallel analysis of D3-5 (CNFY 426-1014), also missing the $\mathrm{N}$-terminal receptor binding domain, confirmed these results (Fig EV4C). This indicated the presence of a second host cell binding site in the C-terminal region, which is strongly supported by the fact that $\mathrm{N}$-terminal deletions missing parts of $\mathrm{D} 1-2\left(\mathrm{CNF}_{\mathrm{Y}} \Delta 39\right.$ 426) are still able to promote cell binding and endosomal uptake as indicated by colocalization studies (Figs 2D and 4).

In E. coli CNF1, the binding site for the Lu/BCAM receptor was shown to include amino acids 720-730 of the catalytic domain (Reppin et al, 2017). The respective segment is significantly different in $\mathrm{CNF}_{\mathrm{Y}}$ (Fig EV1), which may explain why $\mathrm{CNF}_{\mathrm{Y}}$ does not interact with Lu/BCAM. Instead, a recent study has shown that a C-terminal fragment of $\mathrm{CNF}_{Y}$ (residues 709-1014) employs glycosaminoglycans as receptors and is sufficient for endosomal uptake (Kowarschik et al, 2020), in line with the observations made here. Thus CNFY, similar to CNF1 (Piteau et al, 2014; Reppin et al, 2017), contains two distinct host cell binding sites, one each at the $\mathrm{N}$ - and $\mathrm{C}$-terminus. In $\mathrm{CNF}_{\mathrm{Y}}$, these binding sites enable endosomal uptake independently of each other, and the presence of two receptor binding sites might broaden the range of targeted cells or may increase host cell binding affinity.

The D4-5 segment adopts a different conformation and shows increased deamidase activity after cleavage from full-length $C N F_{Y}$

Previous work with E. coli CNF1 demonstrated that translocation releases a fragment consisting of the ART-like domain D4 and the deamidase domain D5 into the cytosol of host cells (Knust et al, 2009). This prompted us to crystallize the respective segment of $\mathrm{CNF}_{\mathrm{Y}}$, leading to a structure in which linker residues V702-L717 again were too flexible to be traced and in which the two domains adopt a different relative orientation with respect to the fulllength protein. Whereas D4 and D5 interacted only weakly in the complete toxin, they now engage in a large interface $\left(1100 \AA^{2}\right)$, whereby the active site crevice of D5 is extended by D4 and becomes fully solvent-exposed (Fig 7A). To reach this position, domain D4 has to rotate by more than $140^{\circ}$, which can probably only be achieved after cleavage from D1-3 
bioRxiv preprint doi: https://doi.org/10.1101/2020.04.07.029181; this version posted September 21, 2020. The copyright holder for this preprint (which was not certified by peer review) is the author/funder, who has granted bioRxiv a license to display the preprint in perpetuity. It is made available under aCC-BY-NC-ND 4.0 International license.

Structure-function analysis of $\mathrm{CNF}_{\mathrm{Y}}$

and through the flexibility of the linker connecting both domains. The contact area between both domains in the free D4-5 subunit overlaps largely with that of D3-5 in the full-length structures such that both conformations are mutually exclusive, i.e. the D4-5 subunit cannot adopt the conformation observed in the free state when it is bound to D1-3.

The finding that the active site within domain D5 becomes more exposed in the recombinant D4-5 fragment suggested that presence of domains D1-3 may repress the deamidase activity of $\mathrm{CNF}_{\mathrm{Y}}$ and that cleavage of the $\mathrm{D} 4-5$ fragment is required to rearrange and liberate and activate the catalytic unit. To test this hypothesis, we incubated equal amounts of purified $\mathrm{CNF}_{\mathrm{Y}}$ 1-1014 (D1-5) and $\mathrm{CNF}_{\mathrm{Y}}$ 526-1014 (D4-5) with host cell extracts or recombinant RhoA and analyzed the deamidation of RhoA in gel-shift assays and with proteomic methods. As shown in Fig 7B-C, RhoA deamidation by CNFY 526-1014 (D4-5) protein was indeed significantly faster than by the full-length protein, indicating that the domain rearrangement seen in the D4-5 fragment enhances the deamidase activity and that the full-length toxin is in an autoinhibited state with respect to this activity.

\section{Discussion}

Here we show that $\mathrm{CNF}_{Y}$ and related CNFs consist of five individual structural building blocks that enable the different steps of the intoxication process, namely secretion, cell attachment, entry, translocation and enzymatic activity. The three N-terminal domains D13 all possess novel folds and constitute the secretion and membrane translocation unit, whereas the two C-terminal domains D4-5 form the toxicity-mediating unit of the toxin. We further show that the D1-3 unit is sufficient to transport cargo proteins such as $\beta$-lactamase into the cytosol of host cells. Strikingly, both the Rho deamidation and $\beta$-lactamase activity were preserved when the reporter was fused to the C-terminal end of the full-length protein (Fig 3), indicating that the secretion and transport module of the $\mathrm{CNF}_{\mathrm{Y}}$ protein is very robust and insensitive to C-terminal extensions, making it an attractive tool for drug delivery.

The molecular mechanisms by which domains D1-3 promote the delivery of the cargo from the bacterial to the host cell cytosol are still unknown. However, considering the 
bioRxiv preprint doi: https://doi.org/10.1101/2020.04.07.029181; this version posted September 21, 2020. The copyright holder for this preprint (which was not certified by peer review) is the author/funder, who has granted bioRxiv a license to display the preprint in perpetuity. It is made available under aCC-BY-NC-ND 4.0 International license.

Structure-function analysis of $\mathrm{CNF}_{\mathrm{Y}}$

compact arrangements of the modules with large hydrophobic interfaces between domains D1 and D2, D3 and D4, as well as D3 and D5, it is likely that the full-length toxin is secreted from the bacterial cell and endocytosed by the host cells as monolithic compact structure. In fact, the $\mathrm{CNF}_{\mathrm{Y}}$ toxin has recently been identified on the surface of outer membrane vesicles (OMVs) isolated from Y. pseudotuberculosis culture supernatants (Monappa et al. 2018). While this could indicate that the toxin might be predominantly delivered into endosomes by OMVs, our data further show that also the purified $\mathrm{CNF}_{Y}$ toxin interacts with and is efficiently internalized into host cells on its own. This suggests that the toxin is also directly secreted by the bacterial cell and/or exposed on the OMVs to promote contact with target cells.

The data presented here further show that the cellular toxin uptake process not only requires segments identified for receptor binding in D2 and for translocation in D1, but also the imperfect $\beta$-barrel domain D3. It is interesting to note that D1 is, due to its mostly $\alpha$ helical character, reminiscent of the translocation machinery of other toxins including that of the diphtheria toxin DT. DT, CNFs and several other AB-type toxins contain two hydrophobic stretches that are believed to fold into $\alpha$-helices and insert into the endosomal membrane after charge neutralization of surrounding acidic residues (Pei et al, 2001; Orrell et al, 2017). In $C N F_{Y}$, the respective residues $350-372$ and $387-412$ were not found in the predicted $\alpha$-helical structure (Fig 1B). However, since the crystal structures presented here have been obtained at neutral $\mathrm{pH}$, it is conceivable that this region undergoes refolding during endosomal acidification. While the precise molecular mechanism of the complex translocation process of CNFY is still unclear (Pitard \& Malliavin, 2019), work with DT suggests that the catalytic subunit of this toxin is unfolded in the translocation process (Murphy, 2011). The fact that (i) translocation in CNFs also involves two hydrophobic motifs interrupted by acidic residues and (ii) the observation that a sequence that gets cleaved to release the catalytic unit (D4-5) of CNF (residues 532 to 544) is not accessible in the fulllength structure (Fig 1C) may hint at a similar unfolding in the CNFs. In this respect, the similarity of parts of the CNFy's D1 domain to the putative translocation domain of nigritroxin 
bioRxiv preprint doi: https://doi.org/10.1101/2020.04.07.029181; this version posted September 21, 2020. The copyright holder for this preprint (which was not certified by peer review) is the author/funder, who has granted bioRxiv a license to display the preprint in perpetuity. It is made available under aCC-BY-NC-ND 4.0 International license.

Structure-function analysis of $\mathrm{CNF}_{\mathrm{Y}}$

(Fig 5A) (Labreuche et al, 2017) is interesting, because the translocation domain of this toxin does not contain hydrophobic $\alpha$-helices. This could indicate that the translocation process occurs through several steps that involve different parts of the translocation machinery, most of which are not shared between the CNFs and nigritoxin.

Sequence searches in the UniRef50 database (Suzek et al, 2015) revealed that large sections of the D1-3 domain of CNFY are also found in a number of un- or less characterized bacterial proteins, suggesting that these proteins are toxins that apparently utilize a similar secretion and translocation device for their catalytic domains (Fig 8). For example, about 530 amino acids of the $\mathrm{N}$-terminus of $\mathrm{CNF}_{\mathrm{Y}}$ share between $30-50 \%$ sequence identity to the N-terminus of Pasteurella multocida toxin PMT (Bergmann et al, 2013). Moreover, members of a group consisting of 372 proteins with approximately 900 residues each were found to possess a canonical RSE-type ART-domain at their C-terminus (represented by UniProt entry A0A0P9UH04 from Pseudomonas syringae pv. maculicola) in addition to a CNF-like translocation apparatus. A second group of 206 proteins with more than 1000 residues contains a C-terminal glycosyltransferase (represented by UniProt entry A0A0N8SZE6 from Pseudomonas syringae pv. syringae). Since the C-termini of these proteins differ from $\mathrm{CNF}_{\mathrm{Y}}$ (Fig 8), it is likely that the toxins consist of individual modules that have been shuffled in the course of evolution. This aligns with a recent analysis of the distribution of CNF-like deamidase domains, which are also found at different positions within the sequence of other toxins or as stand-alone proteins (Cruz-Migoni et al, 2011; Ho et al, 2018).

The finding that the DUF4765 domain D4 shows similarity to ADP-ribosyltransferases was surprising and led us to investigate if the released D4-5 may possess an additional and previously unrecognized enzyme activity that may contribute to the toxicity of CNFs. However, the observation that CNFY toxicity strictly depended on the activity of the deamidase D5 domain whereas mutations of the potential/suggested NAD+ binding domain within D4 had no effect (Appendix Fig S5), together with the fact that we could not detect NAD ${ }^{+}$ binding in biophysical experiments, speaks against such an additional activity. On the other 
bioRxiv preprint doi: https://doi.org/10.1101/2020.04.07.029181; this version posted September 21, 2020. The copyright holder for this preprint (which was not certified by peer review) is the author/funder, who has granted bioRxiv a license to display the preprint in perpetuity. It is made available under aCC-BY-NC-ND 4.0 International license.

Structure-function analysis of $\mathrm{CNF}_{\mathrm{Y}}$

hand, the NAD+ affinity of some ADP-ribosyl transferases is very low. This is exemplified by cholera toxin, where a $K_{D}$ of $4.0 \pm 0.4 \mathrm{mM}$ has been determined (Galloway \& van Heyningen, 1987). Alternatively, the grossly different and mutually exclusive relative orientations of the D4 and D5 domains in the free D4-5 subunit with respect to the full-length CNFY structure (Fig 7) could suggest that D4 may have a regulatory role. On the one hand, the finding that the active site becomes solvent-accessible and that the crevice leading to the active site of D5 becomes extended by parts of D4 (Fig 7) could fine-tune the deamidase function of D5 with respect to general activity levels or substrate specificity towards RhoA, Rac1 or Cdc42. On the other hand, D4 could contribute to localizing the catalytical unit within the host cell by promoting access to membrane-associated Rho GTPases. In fact, CNFs act predominantly on Rho GTPases bound to GTP, a form essentially found at the cytoplasmic face of the host cell membrane (Boquet, 2001). Clearly, the importance of D4 merits future studies.

In summary, the data presented here provide insight into the full-length and released active D4-5 structure, and they illustrate the importance of the individual building blocks of CNFs and related exotoxins. This not only forms the basis for the detailed analysis of the molecular secretion and transport mechanism, but also enables the rational design of the transport module as a toxin-based cargo delivery tool for cytosolic drug/therapeutics delivery and the structure-guided development of inhibitors of CNF-like virulence factors. 
bioRxiv preprint doi: https://doi.org/10.1101/2020.04.07.029181; this version posted September 21, 2020. The copyright holder for this preprint (which was not certified by peer review) is the author/funder, who has granted bioRxiv a license to display the preprint in perpetuity. It is made available under aCC-BY-NC-ND 4.0 International license.

Structure-function analysis of $\mathrm{CNF}_{\mathrm{Y}}$

\section{Materials and Methods}

\section{Bacterial strains, cell lines, plasmids and growth conditions}

All bacterial strains and plasmids used in this study are listed in Appendix Tab S3. All oligonucleotide primers used for cloning are listed in Appendix Tab S4. E. coli strains were grown in Luria-Bertani (LB; Becton Dickinson) broth at $37^{\circ} \mathrm{C}$. Yersinia strains were aerobically grown in $\mathrm{LB}$ at $25^{\circ} \mathrm{C}$ or $37^{\circ} \mathrm{C}$. Other media used for bacterial growth were brainheart infusion broth (BHI) (Gibco) and Double Yeast Tryptone medium (DYT) (Gibco). Cultures were supplemented with $30 \mu \mathrm{g} / \mathrm{ml}$ kanamycin (Kan) or chloramphenicol $(\mathrm{Cm})$ where necessary. HEp-2 cells (ATCC CCL-23) were grown at $37^{\circ} \mathrm{C}, 5 \% \mathrm{CO}_{2}$ in RPMI (Gibco) supplemented with 7.5\% newborn calf serum (NCS; Sigma).

\section{Antibodies}

The following antibodies have been used in this study: anti RhoA from Biomol No. NB26007 and Abcam No. ab54835; anti-actin from Sigma No. A2228-100UL, anti-3x-Flag from Sigma No. F3165-1MG, anti-beta lactamase (TEM) from Abcam No. ab12251, anti-GFP from Sigma No. 11814460001, and anti-IgG from Cell Signalling No. 7076S.

\section{Cloning, expression and purification of recombinant $\mathrm{CNF}_{\mathrm{Y}}$ variants}

For crystallography purposes, truncated constructs were generated comprising a fragment lacking the catalytically active $\mathrm{C}$-terminal domain $\left(\mathrm{CNF}_{\mathrm{Y}} 1-704\right)$, a construct containing both C-terminal domains D4-5 (CNFY526-1014) and another containing only the catalytic domain D5 (CNFY720-1014). For crystallization of the full-length protein, a construct containing the inactive C866S variant of $\mathrm{CNF}_{\mathrm{Y}}$ was produced.

The coding sequences of D4-5 (CNFY1-704) and D5 (CNFY720-1014) were both cloned into pET28c containing sequences coding for an N-terminal hexa-histidine tag and a thrombin protease cleavage site. The constructs were transformed into E. coli BL21 (DE3) $\left(\mathrm{CNF}_{\mathrm{Y} 1-704)}\right.$ or Rosetta II (DE3) (CNFY720-1014). Native protein was expressed in lysogenic broth (LB) medium at $20^{\circ} \mathrm{C}$ after induction with $0.5 \mathrm{mM}$ isopropyl- $\beta-\mathrm{D}$ - 
bioRxiv preprint doi: https://doi.org/10.1101/2020.04.07.029181; this version posted September 21, 2020. The copyright holder for this preprint (which was not certified by peer review) is the author/funder, who has granted bioRxiv a license to display the preprint in perpetuity. It is made available under aCC-BY-NC-ND 4.0 International license.

Structure-function analysis of $\mathrm{CNF}_{\mathrm{Y}}$

thiogalactopyranosid (IPTG) for 16-18 h (D1-4; CNFY1-704) or $4 \mathrm{~h}$ (D5; CNFY720-1024) (5), respectively. Seleno-L-methionine (Se-Met) labeled protein of CNFy1-704 (D1-4) was expressed using M9 minimal medium.

After harvesting, the cell pellets were resuspended in lysis-buffer (for D1-4/CNFY1-704: $1 \times$ PBS, $400 \mathrm{mM} \mathrm{NaCl}, 5 \mathrm{mM} \beta$-mercaptoethanol, $5 \mathrm{mM} \mathrm{MgSO}_{4}, 10 \mathrm{mM}$ imidazole; for D5/CNFy720-1014: $50 \mathrm{mM}$ Tris/HCl pH 8.0, $400 \mathrm{mM} \mathrm{NaCl}, 5 \mathrm{mM}$ imidazole) and lysed by sonification. The supernatant after centrifugation was mixed with $1 \mathrm{ml}$ Ni-NTA resin preequilibrated with wash I buffer (D1-4/CNFy1-704: 1 x PBS, $400 \mathrm{mM} \mathrm{NaCl}, 10 \mathrm{mM}$ imidazole, 5 mM MgSO4, 5 mM ß-mercaptoethanol; D5/CNFY720-1014: 50 mM Tris/HCl pH 8, 400 $\mathrm{mM} \mathrm{NaCl}, 5 \mathrm{mM}$ imidazole) and incubated for $1 \mathrm{~h}$ on an overhead-shaker at $4^{\circ} \mathrm{C}$. After washing with wash I buffer and wash II buffer (D1-4/CNFy1-704: 1 x PBS, $400 \mathrm{mM} \mathrm{NaCl}$, $20 \mathrm{mM}$ imidazole, $5 \mathrm{mM} \mathrm{MgSO}_{4}, 5 \mathrm{mM} \beta$-mercaptoethanol; D5/CNFy720-1014: $50 \mathrm{mM}$ Tris $/ \mathrm{HCl} \mathrm{pH} \mathrm{8,} 400 \mathrm{mM} \mathrm{NaCl}, 20 \mathrm{mM}$ imidazole), elution of the protein was carried out with $12 \times 1 \mathrm{ml}$ of elution buffer (D1-4/CNFy1-704: 1 x PBS, $400 \mathrm{mM} \mathrm{NaCl}, 250 \mathrm{mM}$ imidazole, 5 mM MgSO4, 5 mM ß-mercaptoethanol; D5/CNFY720-1014: 50 mM Tris/HCl, 250 mM NaCl, $250 \mathrm{mM}$ imidazole). Buffer exchange and tag cleavage with thrombin $(1: 50 \mathrm{mg} / \mathrm{mg})$ were achieved over night by dialysis at $4^{\circ} \mathrm{C}$ in wash I buffer. To remove cleaved His-Tag, uncleaved protein and the thrombin protease, $1 \mathrm{ml}$ of Ni-NTA resin and $5 \mathrm{ml}$ of benzamidinesepharose resin, respectively were mixed with the dialyzed protein solution. The collected flow-through predominantly contained pure protein. Further purification was achieved by size-exclusion chromatography. D1-4 (CNFY1-704) was purified using a HiLoad 16/600 Superdex $200 \mathrm{pg}$ (GE Healthcare) pre-equilibrated in buffer containing $20 \mathrm{mM}$ Tris pH 8.0, $150 \mathrm{mM} \mathrm{NaCl}, 5 \mathrm{mM}$ DTT. D5 (CNFY720-1014) was purified using a HiLoad 16/600 Superdex 75 pg (GE Healthcare) pre-equilibrated in buffer containing $25 \mathrm{mM}$ Tris pH 8.0, $100 \mathrm{mM} \mathrm{NaCl}$. The proteins were then concentrated to $20 \mathrm{mg} / \mathrm{ml}$, flash-frozen in liquid nitrogen and stored or directly used for crystallographic screens.

The gene encoding for the full-length protein of the $\mathrm{CNF}_{\mathrm{Y}} \mathrm{C} 866 \mathrm{~S}$ variant was cloned into a modified pCOLA Duet-1 vector (Novagen) encoding for an N-terminal Strep-tag II and 
bioRxiv preprint doi: https://doi.org/10.1101/2020.04.07.029181; this version posted September 21, 2020. The copyright holder for this preprint (which was not certified by peer review) is the author/funder, who has granted bioRxiv a license to display the preprint in perpetuity. It is made available under aCC-BY-NC-ND 4.0 International license.

Structure-function analysis of $\mathrm{CNF}_{\mathrm{Y}}$

TEV-protease recognition site (construct: CNFY C866S). In the case of D4-5 (CNFY 5261014), the insert was amplified from pCNFy3xFlag as template so that the three C-terminal FLAG-epitopes were included in the insert and cloned into the same modified pCOLA Duet1 vector that was also used for the full-length toxin (construct: pVP-CNFy526-1014-3xFlag). Both proteins were heterologously expressed in E. coli BL21 (DE3) in ZYM-5052 autoinducing medium (Studier, 2005) at $20^{\circ} \mathrm{C}$ for $20-24 \mathrm{~h}$.

In the case of D4-5 (CNFy526-1014), the cell pellet was resuspended in a buffer containing $20 \mathrm{mM} \mathrm{HEPES} / \mathrm{NaOH}$ pH 7.5, $300 \mathrm{mM} \mathrm{NaCl}, 2 \mathrm{mM}$ TCEP, one tablet of complete EDTA-free protease inhibitor cocktail (Roche) and lysed by sonication. The protein was isolated from the supernatant after centrifugation for $1 \mathrm{~h}$ at $100.000 \mathrm{xg}$ using a self-packed $10 \mathrm{ml}$ column with Strep-Tactin Superflow High Capacity resin (IBA) and eluted from the column with a single step of $5 \mathrm{mM}$ d-desthiobiotin. The affinity tag was cleaved off with TEV protease $(1: 50 \mathrm{mg} / \mathrm{mg})$ at $4^{\circ} \mathrm{C}$ overnight. Gel filtration was carried out using a HiLoad $16 / 600$ Superdex 200 pg column (GE Healthcare) in 20 mM HEPES/NaOH pH 7.5, 300 mM NaCl, $2 \mathrm{mM}$ TCEP. The peak fractions were concentrated to $5 \mathrm{mg} / \mathrm{ml}$ and flash-frozen in liquid nitrogen for crystallization screening.

For the full-length protein, the cell pellet was resuspended in a buffer containing $20 \mathrm{mM}$ HEPES/ $\mathrm{NaOH} \mathrm{pH} 7.5,100 \mathrm{mM} \mathrm{NaCl}, 1 \mathrm{mM}$ TCEP, one tablet of complete EDTA-free protease inhibitor cocktail (Roche) and lysed by sonication. The protein was isolated from the supernatant after centrifugation for $1 \mathrm{~h}$ at $100.000 \times \mathrm{g}$ using a self-packed $10 \mathrm{ml}$ column with Strep-Tactin Superflow High Capacity resin (IBA) and eluted from the column with a single step of $5 \mathrm{mM}$ d-desthiobiotin. The affinity tag was cleaved off with TEV protease (1:50 $\mathrm{mg} / \mathrm{mg}$ ) at $4^{\circ} \mathrm{C}$ overnight. Gel filtration was carried out using a HiLoad 16/600 Superdex 200 pg column (GE Healthcare) in $20 \mathrm{mM} \mathrm{HEPES/NaOH} \mathrm{pH} \mathrm{7.5,} 100 \mathrm{mM} \mathrm{NaCl}, 1 \mathrm{mM}$ TCEP. The fractions corresponding to the second peak in the chromatogram (elution volume 70 $75 \mathrm{ml}$ ) were pooled and subjected to further size exclusion chromatography on a Superdex 200 Increase 10/300 GL column (GE Healthcare) in the same buffer. The peak fractions were concentrated to $27.5 \mathrm{mg} / \mathrm{ml}$ and flash-frozen in liquid nitrogen for crystallization 
bioRxiv preprint doi: https://doi.org/10.1101/2020.04.07.029181; this version posted September 21, 2020. The copyright holder for this preprint (which was not certified by peer review) is the author/funder, who has granted bioRxiv a license to display the preprint in perpetuity. It is made available under aCC-BY-NC-ND 4.0 International license.

Structure-function analysis of $\mathrm{CNF}_{\mathrm{Y}}$

screening. All chromatographic steps were carried out using an Äkta Purifier system (GE Healthcare). The samples were analyzed by SDS-PAGE (12\%), and protein concentrations were determined from the absorbances at $280 \mathrm{nM}$ with the extinction coefficients as calculated by Protparam (Gasteiger et al, 2003).

$\mathrm{CNF}_{Y}$-TEM fusion proteins were obtained in a similar manner after cloning into $\mathrm{pET} 28 \mathrm{a}$, overexpression in E. coli Rosetta II (DE3) and a two-step purification protocol involving NiNTA affinity and size exclusion chromatography.

\section{Crystallization}

Crystallization trials were set up at room temperature with a HoneyBee 961 crystallization robot (Digilab Genomic Solutions) in Intelli 96-3 plates (Art Robbins Instruments) with 200 $\mathrm{nl}$ protein solution at different concentrations and $200 \mathrm{nl}$ reservoir solution. Native D1-4 (CNFy1-704) was crystallized in 0.1 M Tris pH 7.3-7.9, 0.2 M ammonium sulfate and 19$21 \%(\mathrm{w} / \mathrm{v})$ PEG 5000 MME. The Se-Met derivative of D1-4 (CNFy1-704) was crystallized in 0.1 M tri-sodium citrate $\mathrm{pH}$ 5.9-6.2, $0.2 \mathrm{M}$ ammonium acetate and 28-32\% (w/v) PEG 4000. Macro-seeding was applied in order to obtain well-diffracting crystals. As all tested compounds for cryoprotection were not tolerated by the samples, the crystals were flashcooled without any additional cryoprotection. The catalytic domain D5 (CNFy720-1014) yielded crystals in several PEG or ammonium sulfate containing conditions and the best diffracting crystals were obtained in $0.2 \mathrm{M}$ ammonium fluoride with 20\% (w/v) PEG 3350. Crystals were cryo-protected with either $25 \%$ glycerol or $100 \%$ Type A oil (Hampton Research) prior to flash freezing in liquid nitrogen. A single well-diffracting crystal of D4-5 (CNFy526-1014) was obtained in the presence of $1 \mathrm{mM}$ ATP in a condition containing 0.24 M magnesium chloride, 22.5\% (w/v) PEG 2000 monomethyl ether. The crystal was harvested after 130 days of growth and cryo-protected by addition of $10 \%(\mathrm{v} / \mathrm{v})(2 R, 3 R)$ 2,3-butanediol. A single crystal of sufficient diffraction quality of full-length CNFyC866S was obtained in 1.4 M ammonium sulfate, $0.13 \mathrm{M}$ lithium acetate, 0.1 M HEPES/ $\mathrm{NaOH}$ pH 7.1. 
bioRxiv preprint doi: https://doi.org/10.1101/2020.04.07.029181; this version posted September 21, 2020. The copyright holder for this preprint (which was not certified by peer review) is the author/funder, who has granted bioRxiv a license to display the preprint in perpetuity. It is made available under aCC-BY-NC-ND 4.0 International license.

Structure-function analysis of $\mathrm{CNF}_{\mathrm{Y}}$

The crystal was harvested after 21 days of growth and after removal of satellite crystals cryo-protected by addition of $10 \%(\mathrm{v} / \mathrm{v})(2 R, 3 R)$-2,3-butanediol.

\section{Data collection and processing}

Data collection of native and Se-Met-derivatized D1-4 $\left(\mathrm{CNF}_{\mathrm{Y}} 1-704\right)$ was performed on beamline PXIII of the Swiss Light Source (Paul Scherrer Institute, Villigen, Switzerland) and BESSY BL14.1 (Helmholtz Zentrum Berlin, Germany) (Mueller et al, 2015). High-resolution data of D5 (CNFY 720-1014) were recorded at beamline BL 14.2 of the BESSY II (HelmholtzZentrum Berlin, Germany). Datasets of domain D4-5 (CNFY 526-1014) and full-length $\mathrm{CNF}_{\mathrm{Y}} \mathrm{C8665}$ were measured at beamline X06DA (PXIII) at the Swiss Light Source (Paul Scherrer Institute, Villigen, Switzerland). Data processing was achieved either manually via the XDS software package (Kabsch, 2010) or by using the AutoPROC (Vonrhein et al, 2011) toolbox (Global Phasing) executing XDS (Kabsch, 2010), Pointless (Evans, 2006), and Aimless (Evans \& Murshudov, 2013). All datasets were recorded at a temperature of 100 $\mathrm{K}$.

\section{Structure determination, refinement and model building.}

The structure of domain $\mathrm{D} 1-3\left(\mathrm{CNF}_{\mathrm{Y}}\right.$ 1-704) was solved by single anomalous dispersion (SAD) using data collected at the selenium absorption edge. The initial phases were calculated using AutoSol (Terwilliger et al, 2009) and a partial model was generated running AutoBuild (Terwilliger et al, 2008), both components of the Phenix software package (Adams et al, 2010). The output model was analyzed in Coot (Emsley et al, 2010) and misplaced main chains were removed or corrected manually in order to obtain a reliable search-model for the following molecular replacement procedures against the dataset of native D1-4 (CNFY 1-704) and the full-length C866S variant. The structure of D5 (CNFY $720-$ 1014) was determined by molecular replacement using the structure of the catalytic Cterminal domain of CNF1 from E. coli (PDB: 1HQ0, (Buetow et al, 2001)) as search-model. The structure of domain D4-5 (CNFy526-1014) was determined by molecular replacement 
bioRxiv preprint doi: https://doi.org/10.1101/2020.04.07.029181; this version posted September 21, 2020. The copyright holder for this preprint (which was not certified by peer review) is the author/funder, who has granted bioRxiv a license to display the preprint in perpetuity. It is made available under aCC-BY-NC-ND 4.0 International license.

Structure-function analysis of $\mathrm{CNF}_{\mathrm{Y}}$

using the structure of domain D5 (CNFy 720-1014) and the region comprising residues 526704 from domain D1-4 (CNFy 1-704). Phases for full-length $\mathrm{CNF}_{\mathrm{Y}} \mathrm{C} 866 \mathrm{~S}$ were obtained by using both domain D1-4 (CNFY1-704) and D5 (CNFY720-1014) as search-models in molecular replacement. The molecular replacement procedures were carried out using Phaser (McCoy et al, 2007) from the Phenix suite (Adams et al, 2010). The structural models were built using Coot (Emsley et al, 2010) and crystallographic refinement was performed with Phenix.refine (Afonine et al, 2012) including the addition of hydrogens in riding positions and TLS-refinement. 5\% of random reflections were flagged for the calculation of $\mathrm{R}_{\text {free }}$. The model of domain D1-4 $\left(\mathrm{CNF}_{\mathrm{Y}} 1-704\right)$ was at $3.3 \AA$ resolution and refined to $R / R_{\text {free }}$ of $24 / 27 \%$ in space group $P 2$. The structure of domain D5 (CNFy 720 1014) was at $1.1 \AA$ resolution and refined to $R / R_{\text {free }}$ of $17 / 18 \%$ in space group $P 2{ }_{1}$. The structure of domain $\mathrm{D} 4-5$ (CNFy526-1014) was at $1.8 \AA$ resolution and refined to $\mathrm{R} / \mathrm{R}_{\text {free }}$ of $16 / 19 \%$ in space group $\mathrm{P} 2{ }_{1} 2_{1} 2_{1}$. The structural model of the full-length C866S variant of $C N F_{Y}$ was at $2.7 \AA$ resolution and refined to $R / R_{\text {free }}$ of $21 / 24 \%$ in space group $122_{1} 2_{2}$. Data collection and refinement statistics are summarized in Tab EV1. Figures of crystal structures were prepared using the PyMOL Molecular Graphics System version 2.0.0 (Schrödinger, LLC).

\section{Construction of fusion plasmids and C-terminal $c n f Y$ deletions}

To construct the plasmids for $\mathrm{CNF}_{\mathrm{y}}$ fusion proteins, the blaM gene and the 3xFlag tag were amplified using primers listed in Appendix Tab S4. pFU189 was used as a backbone from which the luxCDABE operon was removed by digestion with Pstl and Notl after which blaM or the 3xFlag tag were ligated into the vector, resulting in PTEM and p3xFLAG, respectively.

The PCR fragments of C-terminal $c n f Y$ deletions containing the $c n f Y$ promoter region were cloned into the BamHI and Pstl sites of pTEM and p3xFLAG using the Quick-Fusion cloning kit (Biotool) with primers listed in Appendix Tab S4. For the construction of pCNFyGFP, gfp was excised from pFU31 and ligated into the Pstl and Notl sites of digested pCNFY-TEM. All clones were transformed into E. coli DH1Oß and confirmed by sequencing. 
bioRxiv preprint doi: https://doi.org/10.1101/2020.04.07.029181; this version posted September 21, 2020. The copyright holder for this preprint (which was not certified by peer review) is the author/funder, who has granted bioRxiv a license to display the preprint in perpetuity. It is made available under aCC-BY-NC-ND 4.0 International license.

Structure-function analysis of $\mathrm{CNF}_{\mathrm{Y}}$

The plasmids were electroporated into Y. pseudotuberculosis YP147 ( $\Delta c n f Y)$ and selected for on LB agar plates containing the appropriate antibiotics.

\section{Site-directed mutagenesis of $c n f Y$}

Single residue mutants were generated by site-directed mutagenesis with primers listed in Appendix Tab S4. pCNFY-TEM, pCNFY-3xFLAG were used as templates. Clones were selected on LB containing the appropriate antibiotics. Mutations were verified by DNA sequencing.

\section{Detection of fusion proteins by immunoblotting}

For protein expression, strain YP147 harboring the overexpression plasmids encoding fulllength $\mathrm{CNF}_{\mathrm{Y}}$ or the deletion variants was grown in $\mathrm{BHI}$ at $25^{\circ} \mathrm{C}$ overnight. Cells were harvested by centrifugation at $6,500 \mathrm{rpm}$ and $4^{\circ} \mathrm{C}$ for $5 \mathrm{~min}$. Cell pellets were washed with PBS and resuspended with lysis buffer (50 mM Tris- $\mathrm{HCl} \mathrm{pH} \mathrm{7.5,} 100 \mathrm{mM} \mathrm{NaCl}, 5 \mathrm{mM} \mathrm{MgCl}_{2}$, $0.3 \%$ Triton X-100, $3 \mathrm{mg} / \mathrm{ml}$ lysozyme and protease inhibitor cocktail). After incubation at room temperature for $1 \mathrm{~h}$, protein samples were centrifuged for $10 \mathrm{~min}$ and supernatants were sterilized with a $0.2 \mu \mathrm{m}$ filter. To detect proteins, Western blot analysis was performed. The proteins were separated on a 10\% SDS-polyacrylamide gel and transferred onto an Immobilon PVDF membrane (Millipore). Membranes were blocked in 5\% BSA/TBST at $4^{\circ} \mathrm{C}$ overnight. Subsequently, the membrane was washed and incubated with primary antibody diluted in 5\% BSA/TBST (1:10,000 anti-Flag (Sigma-Aldrich) or anti-Beta lactamase (Abcam)) at room temperature for $1 \mathrm{~h}$. After washing, the secondary antibody diluted in $5 \%$ skim milk/TBST (1:5,000 anti-mouse IgG HRP (Cell Signaling Technology)) was added for $30 \mathrm{~min}$ at room temperature. After washing the membrane, proteins were visualized using the Western Lightning ECL II Kit (Perkin Elmer) and exposed on X-Ray film (GE Healthcare Amersham Hyperfilm ECL, Fisher Scientific). 
bioRxiv preprint doi: https://doi.org/10.1101/2020.04.07.029181; this version posted September 21, 2020. The copyright holder for this preprint (which was not certified by peer review) is the author/funder, who has granted bioRxiv a license to display the preprint in perpetuity. It is made available under aCC-BY-NC-ND 4.0 International license.

Structure-function analysis of $\mathrm{CNF}_{Y}$

\section{Nitrocefin secretion assay}

Bacteria were grown overnight at $25^{\circ} \mathrm{C}$ in $\mathrm{BHI}$ containing the appropriate antibiotics. Subsequently, equal amounts of bacteria were pelleted by centrifugation at 13,000 rpm for $10 \mathrm{~min} .95 \mu \mathrm{l}$ of each supernatant was transferred to a 96 -well plate in triplicate. $5 \mu \mathrm{l}$ nitrocefin $(2 \mathrm{mM})$ were added to each well and the plate was incubated at room temperature for $30 \mathrm{~min}$. Beta-lactamase activity was determined at $390 \mathrm{~nm}$ (yellow) and $486 \mathrm{~nm}$ (red) using a VarioSkan plate reader (Thermo Scientific).

\section{Microbial viability assay}

The microbial viability was assessed in equalized bacterial cultures using the BacTiterGlo $^{\mathrm{TM}}$ Microbial Cell Viability Assay kit (Promega) according to the manufacturer's recommendations and luminescence was measured using a VarioSkan plate reader (Thermo Scientific).

\section{Fluorescent actin staining}

HEp-2 cells were seeded onto coverslips at a concentration of $5 \times 10^{4}$ cells/well and allowed to attach overnight. The next day, cells were washed and incubated with an equal amount of cleared bacterial cell lysates for $24 \mathrm{~h}$ at $37^{\circ} \mathrm{C}, 5 \% \mathrm{CO}_{2}$. After washing with PBS, cells were fixed in $4 \%$ paraformaldehyde for $15 \mathrm{~min}$ at room temperature. Subsequently, washed cells were permeabilized with $0.1 \%$ Triton X-100 in PBS for $1 \mathrm{~min}$. The actin cytoskeleton was stained with FITC- or TRITC-Phalloidin ( $0.5 \mu \mathrm{g} / \mathrm{ml}$ in PBS; Sigma-Aldrich) and mounted on slides using ProLong® Gold Antifade mounting medium containing DAPI (Thermo scientific). Cells were visualized by fluorescence microscopy using an Axiovert II inverted fluorescence microscope (Carl Zeiss) with Axiocam HR and the AxioVision program (Carl Zeiss). 
bioRxiv preprint doi: https://doi.org/10.1101/2020.04.07.029181; this version posted September 21, 2020. The copyright holder for this preprint (which was not certified by peer review) is the author/funder, who has granted bioRxiv a license to display the preprint in perpetuity. It is made available under aCC-BY-NC-ND 4.0 International license.

Structure-function analysis of $\mathrm{CNF}_{\mathrm{Y}}$

\section{$\mathrm{CNF}_{\mathrm{Y}}$ translocation assay}

In order to study the CNFY translocation into the host cells, a $\beta$-lactamase (TEM) reporter assay was performed using the LiveBLAzer-FRET B/G Loading Kit (Life Technologies). HEp-2 cells were seeded in 8-well $\mu$-slides (Ibidi) at a concentration of $1.7 \times 10^{4}$ cells/well and allowed to attach overnight. The next day, cells were washed and incubated for $24 \mathrm{~h}$ at $37^{\circ} \mathrm{C}, 5 \% \mathrm{CO}_{2}$ with $20 \mu \mathrm{g} / \mathrm{ml}$ cleared lysates of $Y$. pseudotuberculosis expressing the different $\mathrm{CNF}_{\mathrm{Y}}$-TEM fusion proteins. Cells were washed with PBS, followed by the addition of fresh media containing $20 \mathrm{mM}$ HEPES. Cells were then stained with loading dye according to the manufacturer's protocol. After staining for $1 \mathrm{~h}$ at room temperature, translocation was visualized by fluorescence microscopy using an Axiovert II with Axiocam HR and the AxioVision program (Carl Zeiss).

For the analysis of the translocation dynamics of $\mathrm{CNF}_{Y} 1-1014$ and $\mathrm{CNF}_{Y} 1-526$, surfaceattached HEp-2 cells were charged with CCF4-AM in the dark for $1 \mathrm{~h}$ at $37^{\circ} \mathrm{C}$ and the change of fluorescence was immediately followed after addition of the respective $\mathrm{CNF}_{Y^{-}}$ TEM fusion construct in $Y$. pseudotuberculosis lysates $(20 \mu \mathrm{g} / \mathrm{ml})$ or the purified recombinant proteins (200 nM), using a CLARIOstar Plus fluorometer (BMG Labtech) or a Cytation 5 plate reader (Biotek), respectively.

\section{Fluorescence microscopy to visualize endocytosis}

To test whether the CNFy deletion constructs are able to enter the cells through the endocytotic pathway, CellLight ${ }^{\circledR}$ Early or late Endosomes-RFP, BacMam 2.0 (Thermo Scientific) were used to investigate toxin entry to the host cells. HEp-2 cells were seeded $5 \times 10^{4}$ cells $/ \mathrm{ml}$ onto coverslips in 24 well plates and allowed to attach overnight. The next day, CellLight $\circledast$ reagent was added to HEp-2 cells around 20 particles per cells for $16 \mathrm{~h}$ and the cells were then incubated with $\mathrm{CNF}_{\mathrm{Y}}$ toxin on ice for $30 \mathrm{~min}$. Subsequently, cells were washed and transferred to $37^{\circ} \mathrm{C}$ for 30,90 or $180 \mathrm{~min}$. To investigate colocalization of $\mathrm{CNF}_{\mathrm{Y}}$ with early or late endosome, cells were then fixed and visualized by using a fluorescence 
bioRxiv preprint doi: https://doi.org/10.1101/2020.04.07.029181; this version posted September 21, 2020. The copyright holder for this preprint (which was not certified by peer review) is the author/funder, who has granted bioRxiv a license to display the preprint in perpetuity. It is made available under aCC-BY-NC-ND 4.0 International license.

Structure-function analysis of $\mathrm{CNF}_{\mathrm{Y}}$

microscope (Axiovert II with Axiocam HR, Carl Zeiss) and the AxioVision program (Carl Zeiss).

\section{Biochemical analysis of RhoA deamidation}

Cells were seeded in $10 \mathrm{~cm}$ cell culture dishes at the concentration of $2.2 \times 10^{6} \mathrm{cell} / \mathrm{s} / \mathrm{dish}$ and allowed to attach overnight. The next day, cells were washed and incubated for $4 \mathrm{~h}$ with $20 \mu \mathrm{g} / \mathrm{ml}$ of cleared lysates from $Y$. pseudotuberculosis expressing different $\mathrm{CNF}_{Y}$ derivatives at $37^{\circ} \mathrm{C}, 5 \% \mathrm{CO}_{2}$. Cells were washed with cold PBS and lysed in $150 \mu$ lysis buffer containing $50 \mathrm{mM}$ Tris- $\mathrm{HCl}$ (pH7.4), $100 \mathrm{mM} \mathrm{NaCl}, 2 \mathrm{mM} \mathrm{MgCl}, 10 \% \mathrm{NP}-40$ and 0.5 mM phenyl-methyl-sulfonyl fluoride (PMSF). Cells were then scraped off and centrifuged for $30 \mathrm{~min}\left(13,000 \mathrm{rpm}, 4^{\circ} \mathrm{C}\right)$. Sodium dodecyl sulfate (SDS) sample buffer was added to the clear lysates and samples were separated on 12\% SDS-gel. After blotting onto a PVDF membrane, RhoA was detected using mouse anti-RhoA IgG (Millipore) (1:1000) as a primary antibody and followed by secondary antibody goat anti-mouse IgG-HRP (Cell signaling). Membranes were visualized using the Western Lightning ECL II Kit (Perkin Elmer) and exposed on X-Ray film.

\section{In vitro RhoA shift assay}

In vitro RhoA shift assays were performed in order to check for proper folding and catalytic activity of $\mathrm{CNF}_{\mathrm{Y}}$ deletion constructs. Cells were seeded on $150 \mathrm{~mm}$ dish at the concentration of $5 \times 10^{6} \mathrm{cells} / \mathrm{dish}$ and allowed to attach overnight. The next day, cells were washed with PBS and lysed in $300 \mu$ lysis buffer (50 mM Tris-HCl, pH 7.5, 5 mM MgCl, 1 mM EDTA, 10\% NP-40 and 1 mM dithiothreitol (DTT)). Cells were then scraped off and centrifuged $13,000 \mathrm{rpm}$ at $4^{\circ} \mathrm{C}$ for $30 \mathrm{~min} .20 \mu \mathrm{g} / \mathrm{ml}$ of cleared lysates from $Y$. pseudotuberculosis expressing different $\mathrm{CNF}_{Y}$ derivatives were added to the prepared cell extracts and then incubated for $4 \mathrm{~h}$, or $1 \mu \mathrm{M}$ purified $\mathrm{CNF}_{\mathrm{Y}}$ or $\mathrm{CNF}_{\mathrm{Y}}$ 526-1014 protein were incubated in the cell extracts for $10-60 \mathrm{~min}$ at $37^{\circ}$. The reactions were stopped by adding SDS-sample buffer 
bioRxiv preprint doi: https://doi.org/10.1101/2020.04.07.029181; this version posted September 21, 2020. The copyright holder for this preprint (which was not certified by peer review) is the author/funder, who has granted bioRxiv a license to display the preprint in perpetuity. It is made available under aCC-BY-NC-ND 4.0 International license.

Structure-function analysis of $\mathrm{CNF}_{\mathrm{Y}}$

and heated at $95^{\circ} \mathrm{C}$ for $10 \mathrm{~min}$. Samples were then subjected to $12 \%$ SDS-PAGE. After blotting onto a PVDF membrane, blots were developed as mentioned above.

\section{Quantification of RhoA deamidation by mass spectrometry}

Recombinant RhoA $(20 \mu \mathrm{M})$ was incubated at $37^{\circ} \mathrm{C}$ with full-length $\mathrm{CNF}_{\mathrm{Y}}$ or $\mathrm{CNF}_{\mathrm{Y}} 526-1014$ in $100 \mu \mathrm{l}$ assay-buffer (20 mM HEPES/ $\mathrm{NaOH}, 300 \mathrm{mM} \mathrm{NaCl}, 2 \mathrm{mM} \mathrm{MgCl}$, $2 \mathrm{mM}$ TCEP, $100 \mu \mathrm{M}$ GDP). Samples, after setup for $30 \mathrm{~min}, 3 \mathrm{~h}$ and $16 \mathrm{~h}$, were immediately mixed with 2-fold SDS-PAGE loading buffer, denatured for $5 \mathrm{~min}$ at $95^{\circ} \mathrm{C}$ and subjected to SDS-PAGE by applying $2 \mu \mathrm{g}$ of RhoA per lane. After staining with Coomassie Blue, bands corresponding to RhoA were cut out, destained with $30 \%$ acetonitrile in $50 \mathrm{mM} \mathrm{TEAB}$ and then dehydrated with 100\% acetonitrile. After reduction with 20 mM TCEP in 50 mM TEAB ( $\left.1 \mathrm{~h}, 56^{\circ} \mathrm{C}\right)$, alkylation was performed by $20 \mathrm{mM}$ MMTS in $50 \mathrm{mM}$ TEAB $(1 \mathrm{~h}, \mathrm{RT})$, followed by in-gel digestion over night with $50 \mathrm{ng}$ trypsin (Promega) in 50 mM TEAB. Peptides were extracted by using 10 gel volumes of $0.5 \%$ formic acid in 30\% acetonitrile, vacuum dried and resuspended in $0.1 \%$ formic acid before applying to Evotips as recommended by the manufacturer (Evosep). Peptide sequencing of RhoA was carried out by tandem mass spectrometry on an Evosep One HPLC system linked with a timsTOF Pro mass spectrometer (Bruker). Separation of modified peptide ions was supported by ion mobility and RhoA deamidation in the peptide QVELALWDTAGQEDYDR was identified by using PEAKS 10+ software. Deamidated and corresponding non-deamidated RhoA peptide variants were manually validated at the level of their distinct HPLC-retention times and corresponding representative fragmentation spectra (MS2; Data Analysis, Bruker). RhoA modification was then quantified by selected ion chromatograms (MS1; Data Analysis, Bruker). $\mathrm{CNF}_{\mathrm{Y}}$-dependent deamidation was determined in comparison to non-treated RhoA samples (negative control) and based on the area under peaks for double charged nondeamidated peptides $(\mathrm{m} / \mathrm{z} 1004.9645 \pm 0.005)$ and deamidated peptides (retention time + $0.3 \mathrm{~min}, \mathrm{~m} / \mathrm{z} 1005.4590 \pm 0.005$ ). 
bioRxiv preprint doi: https://doi.org/10.1101/2020.04.07.029181; this version posted September $21,2020$. The copyright holder for this preprint (which was not certified by peer review) is the author/funder, who has granted bioRxiv a license to display the preprint in perpetuity. It is made available under aCC-BY-NC-ND 4.0 International license.

Structure-function analysis of $\mathrm{CNF}_{\mathrm{Y}}$

\section{References}

Adams PD, Afonine PV, Bunkóczi G, Chen VB, Davis IW, Echols N, Headd JJ, Hung L-W, Kapral GJ, Grosse-Kunstleve RW, McCoy AJ, Moriarty NW, Oeffner R, Read RJ, Richardson DC, Richardson JS, Terwilliger TC \& Zwart PH (2010) PHENIX: a comprehensive Python-based system for macromolecular structure solution. Acta Crystallogr. D Biol. Crystallogr 66: 213-221

Afonine PV, Grosse-Kunstleve RW, Echols N, Headd JJ, Moriarty NW, Mustyakimov M, Terwilliger TC, Urzhumtsev A, Zwart PH \& Adams PD (2012) Towards automated crystallographic structure refinement with phenix.refine. Acta Crystallographica Section $D$ Biological Crystallography 68: 352-367

Aleksiev T, Potestio R, Pontiggia F, Cozzini S \& Micheletti C (2009) PiSQRD: a web server for decomposing proteins into quasi-rigid dynamical domains. Bioinformatics 25: 2743-2744

Bergmann S, Jehle D, Schwan C, Orth JHC \& Aktories K (2013) Pasteurella multocida Toxin as a Transporter of Non-Cell-Permeating Proteins. Infection and Immunity 81: 2459-2467

Berman HM, Westbrook J, Feng Z, Gilliland G, Bhat TN, Weissig H, Shindyalov IN \& Bourne PE (2000) The Protein Data Bank. Nucleic Acids Res 28: 235-242

Blumenthal B, Hoffmann C, Aktories K, Backert S \& Schmidt G (2007) The cytotoxic necrotizing factors from Yersinia pseudotuberculosis and from Escherichia coli bind to different cellular receptors but take the same route to the cytosol. Infect. Immun. 75: 3344-3353

Boquet $\mathrm{P}$ (2001) The cytotoxic necrotizing factor 1 (CNF1) from Escherichia coli. Toxicon 39: $1673-1680$

Buetow L, Flatau G, Chiu K, Boquet P \& Ghosh P (2001) Structure of the Rho-activating domain of Escherichia coli cytotoxic necrotizing factor 1. Nat. Struct. Biol. 8: 584-588

Buetow L, Flatau G, Chiu K, Boquet P \& Ghosh P (2002) Strategies for the structural determination of the catalytic domain of Escherichia coli cytotoxic necrotizing factor 1 . Acta Crystallogr D Biol Crystallogr 58: 366-9

Cavaillon J-M (2018) Exotoxins and endotoxins: Inducers of inflammatory cytokines. Toxicon 149: 45-53

Chung JW, Hong SJ, Kim KJ, Goti D, Stins MF, Shin S, Dawson VL, Dawson TM \& Kim KS (2003) 37-kDa laminin receptor precursor modulates cytotoxic necrotizing factor 1mediated RhoA activation and bacterial uptake. J. Biol. Chem. 278: 16857-16862

Clemons NC, Bannai Y, Haywood EE, Xu Y, Buschbach JD, Ho M \& Wilson BA (2018) Cytosolic Delivery of Multidomain Cargos by the N Terminus of Pasteurella multocida Toxin. Infect. Immun. 86:

Cohen MS \& Chang P (2018) Insights into the biogenesis, function, and regulation of ADP-ribosylation. Nat. Chem. Biol. 14: 236-243

Cruz-Migoni A, Hautbergue GM, Artymiuk PJ, Baker PJ, Bokori-Brown M, Chang C-T, Dickman MJ, Essex-Lopresti A, Harding SV, Mahadi NM, Marshall LE, Mobbs GW, Mohamed R, Nathan S, Ngugi SA, Ong C, Ooi WF, Partridge LJ, Phillips HL, Raih MF, et al (2011) A Burkholderia pseudomallei toxin inhibits helicase activity of translation factor elF4A. Science 334: 821-824

Diabate M, Munro P, Garcia E, Jacquel A, Michel G, Obba S, Goncalves D, Luci C, Marchetti S, Demon D, Degos C, Bechah Y, Mege JL, Lamkanfi M, Auberger P, Gorvel JP, Stuart LM, Landraud L, Lemichez E \& Boyer L (2015) Escherichia coli alpha- 
bioRxiv preprint doi: https://doi.org/10.1101/2020.04.07.029181; this version posted September $21,2020$. The copyright holder for this preprint (which was not certified by peer review) is the author/funder, who has granted bioRxiv a license to display the preprint in perpetuity. It is made available under aCC-BY-NC-ND 4.0 International license.

Structure-function analysis of $\mathrm{CNF}_{\mathrm{Y}}$

hemolysin counteracts the anti-virulence innate immune response triggered by the Rho GTPase activating toxin CNF1 during bacteremia. PLoS Pathog 11: e1004732

Diana G, Valentini G, Travaglione S, Falzano L, Pieri M, Zona C, Meschini S, Fabbri A \& Fiorentini C (2007) Enhancement of learning and memory after activation of cerebral Rho GTPases. Proc. Natl. Acad. Sci. U.S.A. 104: 636-641

Emsley P, Lohkamp B, Scott WG \& Cowtan K (2010) Features and development of Coot. Acta Crystallogr. D Biol. Crystallogr. 66: 486-501

Evans P (2006) Scaling and assessment of data quality. Acta Crystallogr. D Biol. Crystallogr. 62: 72-82

Evans PR \& Murshudov GN (2013) How good are my data and what is the resolution? Acta Crystallogr. D Biol. Crystallogr. 69: 1204-1214

Fabbri A, Gauthier M \& Boquet P (1999) The 5' region of cnf1 harbours a translational regulatory mechanism for CNF1 synthesis and encodes the cell-binding domain of the toxin. Mol. Microbiol. 33: 108-118

Fabbri A, Travaglione S, Ballan G, Loizzo S \& Fiorentini C (2013) The cytotoxic necrotizing factor 1 from E. coli: a janus toxin playing with cancer regulators. Toxins (Basel) 5: 1462-1474

Fabbri A, Travaglione S, Maroccia Z, Guidotti M, Pierri CL, Primiano G, Servidei S, Loizzo S \& Fiorentini C (2018) The Bacterial Protein CNF1 as a Potential Therapeutic Strategy against Mitochondrial Diseases: A Pilot Study. Int J Mol Sci 19:

Fabbri A, Travaglione S, Rosadi F, Ballan G, Maroccia Z, Giambenedetti M, Guidotti M, Ødum N, Krejsgaard T \& Fiorentini C (2019) The Escherichia coli protein toxin cytotoxic necrotizing factor 1 induces epithelial mesenchymal transition. Cell. Microbiol.: e13138

Falzano L, Fiorentini C, Donelli G, Michel E, Kocks C, Cossart P, Cabanie L, Oswald E \& Boquet $P(1993)$ Induction of phagocytic behaviour in human epithelial cells by Escherichia coli cytotoxic necrotizing factor type 1. Mol Microbiol 9: 1247-54

Fieldhouse RJ \& Merrill AR (2008) Needle in the haystack: structure-based toxin discovery. Trends Biochem. Sci. 33: 546-556

Flatau G, Lemichez E, Gauthier M, Chardin P, Paris S, Fiorentini C \& Boquet P (1997) Toxin-induced activation of the $G$ protein p21 Rho by deamidation of glutamine. Nature 387: 729-733

Fournout S, Dozois C, Odin M, Desautels C, Pérès S, Hérault F, Daigle F, Segafredo C, Laffitte J, Oswald E, Fairbrother J \& Oswald I (2000) Lack of a role of cytotoxic necrotizing factor 1 toxin from Escherichia coli in bacterial pathogenicity and host cytokine response in infected germfree piglets. Infect Immun. 68: 839-847

Galloway TS \& van Heyningen S (1987) Binding of NAD+ by cholera toxin. Biochem. J. 244: 225-230

Gasteiger E, Gattiker A, Hoogland C, Ivanyi I, Appel RD \& Bairoch A (2003) ExPASy: The proteomics server for in-depth protein knowledge and analysis. Nucleic Acids Res. 31: 3784-3788

Haywood EE, Ho M \& Wilson BA (2018) Modular domain swapping among the bacterial cytotoxic necrotizing factor (CNF) family for efficient cargo delivery into mammalian cells. J. Biol. Chem. 293: 3860-3870

Heine W, Beckstette M, Heroven AK, Thiemann S, Heise U, Nuss AM, Pisano F, Strowig T \& Dersch P (2018) Loss of CNFY toxin-induced inflammation drives Yersinia pseudotuberculosis into persistency. PLoS Pathog. 14: e1006858 
bioRxiv preprint doi: https://doi.org/10.1101/2020.04.07.029181; this version posted September $21,2020$. The copyright holder for this preprint (which was not certified by peer review) is the author/funder, who has granted bioRxiv a license to display the preprint in perpetuity. It is made available under aCC-BY-NC-ND 4.0 International license.

Structure-function analysis of $\mathrm{CNF}_{\mathrm{Y}}$

Ho M, Mettouchi A, Wilson BA \& Lemichez E (2018) CNF1-like deamidase domains: common Lego bricks among cancer-promoting immunomodulatory bacterial virulence factors. Pathog Dis 76:

Hodge R \& Ridley A (2016) Regulating Rho GTPases and their regulators. Nat Rev Mol Cell Biol. 17: 496-510

Hoffmann C, Aktories K \& Schmidt G (2007) Change in substrate specificity of cytotoxic necrotizing factor unmasks proteasome-independent down-regulation of constitutively active RhoA. J. Biol. Chem. 282: 10826-10832

Hoffmann C, Pop M, Leemhuis J, Schirmer J, Aktories K \& Schmidt G (2004) The Yersinia pseudotuberculosis cytotoxic necrotizing factor (CNFY) selectively activates RhoA. J. Biol. Chem. 279: 16026-16032

Holm L \& Rosenström P (2010) Dali server: conservation mapping in 3D. Nucleic Acids Res 38 Suppl: W545-549

Jørgensen R, Wang Y, Visschedyk D \& Merrill AR (2008) The nature and character of the transition state for the ADP-ribosyltransferase reaction. EMBO Rep. 9: 802-809

Kabsch W (2010) XDS. Acta Crystallogr. D Biol. Crystallogr 66: 125-132

Khan NA, Wang Y, Kim KJ, Chung JW, Wass CA \& Kim KS (2002) Cytotoxic necrotizing factor-1 contributes to Escherichia coli K1 invasion of the central nervous system. J Biol Chem 277: 15607-12

Kim KJ, Chung JW \& Kim KS (2005) 67-kDa laminin receptor promotes internalization of cytotoxic necrotizing factor 1-expressing Escherichia coli K1 into human brain microvascular endothelial cells. J. Biol. Chem. 280: 1360-1368

Knust Z, Blumenthal B, Aktories K \& Schmidt G (2009) Cleavage of Escherichia coli cytotoxic necrotizing factor 1 is required for full biologic activity. Infect. Immun. 77: 18351841

Knust Z \& Schmidt G (2010) Cytotoxic Necrotizing Factors (CNFs)-A Growing Toxin Family. Toxins (Basel) 2: 116-27

Koornhof HJ, Smego RA \& Nicol M (1999a) Yersiniosis. II: The pathogenesis of Yersinia infections. Eur J Clin Microbiol Infect Dis 18: 87-112

Koornhof HJ, Smego RA \& Nicol M (1999b) Yersiniosis. II: The pathogenesis of Yersinia infections. Eur. J. Clin. Microbiol. Infect. Dis. 18: 87-112

Kowarschik S, Schöllkopf J, Müller T, Tian S, Knerr J, Bakker H, Rein S, Dong M, Weber S, Grosse R \& Schmidt G (2020) Glycosaminoglycans are specific endosomal receptors for Yersinia pseudotuberculosis Cytotoxic Necrotizing Factor. bioRxiv: 2020.05.18.101790

Krissinel E \& Henrick K (2007) Inference of Macromolecular Assemblies from Crystalline State. Journal of Molecular Biology 372: 774-797

Labreuche $Y$, Chenivesse $S$, Jeudy A, Le Panse S, Boulo V, Ansquer D, Pagès S, Givaudan A, Czjzek M \& Le Roux F (2017) Nigritoxin is a bacterial toxin for crustaceans and insects. Nat Commun 8: 1248

Maroccia Z, Loizzo S, Travaglione S, Frank C, Fabbri A \& Fiorentini C (2018) New therapeutics from Nature: The odd case of the bacterial cytotoxic necrotizing factor 1 . Biomed. Pharmacother. 101: 929-937

McCoy AJ, Grosse-Kunstleve RW, Adams PD, Winn MD, Storoni LC \& Read RJ (2007) Phaser crystallographic software. J Appl Crystallogr 40: 658-674

McNichol BA, Rasmussen SB, Carvalho HM, Meysick KC \& O'Brien AD (2007) Two domains of cytotoxic necrotizing factor type 1 bind the cellular receptor, laminin receptor precursor protein. Infect. Immun. 75: 5095-5104 
bioRxiv preprint doi: https://doi.org/10.1101/2020.04.07.029181; this version posted September $21,2020$. The copyright holder for this preprint (which was not certified by peer review) is the author/funder, who has granted bioRxiv a license to display the preprint in perpetuity. It is made available under aCC-BY-NC-ND 4.0 International license.

Structure-function analysis of $\mathrm{CNF}_{\mathrm{Y}}$

Morgan RN, Saleh SE, Farrag HA \& Aboulwafa MM (2019) Prevalence and pathologic effects of colibactin and cytotoxic necrotizing factor-1 (Cnf 1) in Escherichia coli: experimental and bioinformatics analyses. Gut Pathog 11: 22

Mueller U, Förster R, Hellmig M, Huschmann FU, Kastner A, Malecki P, Pühringer S, Röwer M, Sparta K, Steffien M, Ühlein M, Wilk P \& Weiss MS (2015) The macromolecular crystallography beamlines at BESSY II of the Helmholtz-Zentrum Berlin: Current status and perspectives. Eur. Phys. J. Plus 130: 141

Murphy JR (2011) Mechanism of Diphtheria Toxin Catalytic Domain Delivery to the Eukaryotic Cell Cytosol and the Cellular Factors that Directly Participate in the Process. Toxins 3: 294-308

Orrell KE, Zhang Z, Sugiman-Marangos SN \& Melnyk RA (2017) Clostridium difficile toxins A and B: Receptors, pores, and translocation into cells. Crit. Rev. Biochem. Mol. Biol. 52: 461-473

Pei S, Doye A \& Boquet P (2001) Mutation of specific acidic residues of the CNF1 T domain into lysine alters cell membrane translocation of the toxin. Mol. Microbiol. 41: 1237-1247

Pitard I \& Malliavin TE (2019) Structural Biology and Molecular Modeling to Analyze the Entry of Bacterial Toxins and Virulence Factors into Host Cells. Toxins (Basel) 11:

Piteau M, Papatheodorou P, Schwan C, Schlosser A, Aktories K \& Schmidt G (2014) Lu/BCAM adhesion glycoprotein is a receptor for Escherichia coli Cytotoxic Necrotizing Factor 1 (CNF1). PLoS Pathog. 10: e1003884

Popoff MR (2005) Bacterial exotoxins. Contrib Microbiol 12: 28-54

Reppin F, Cochet S, El Nemer W, Fritz G \& Schmidt G (2017) High Affinity Binding of Escherichia coli Cytotoxic Necrotizing Factor 1 (CNF1) to Lu/BCAM Adhesion Glycoprotein. Toxins (Basel) 10:

Rippere-Lampe KE, Lang M, Ceri H, Olson M, Lockman HA \& O'Brien AD (2001) Cytotoxic necrotizing factor type 1-positive Escherichia coli causes increased inflammation and tissue damage to the prostate in a rat prostatitis model. Infect Immun 69: 6515-9

Schmidt G, Sehr P, Wilm M, Selzer J, Mann M \& Aktories K (1997) Gln 63 of Rho is deamidated by Escherichia coli cytotoxic necrotizing factor-1. Nature 387: 725-729

Schweer J, Kulkarni D, Kochut A, Pezoldt J, Pisano F, Pils MC, Genth H, Huehn J \& Dersch P (2013) The cytotoxic necrotizing factor of Yersinia pseudotuberculosis (CNFY) enhances inflammation and Yop delivery during infection by activation of Rho GTPases. PLoS Pathog. 9: e1003746

Smego RA, Frean J, Koornhof \& H. J (1999) Yersiniosis I: Microbiological and clinicoepidemiological aspects of plague and non-plague Yersinia infections. Eur. J. Clin. Microbiol. Infect. Dis. 18: 1-15

Studier FW (2005) Protein production by auto-induction in high density shaking cultures. Protein Expr. Purif. 41: 207-234

Suzek BE, Wang Y, Huang H, McGarvey PB \& Wu CH (2015) UniRef clusters: a comprehensive and scalable alternative for improving sequence similarity searches. Bioinformatics 31: 926-932

Terwilliger TC, Adams PD, Read RJ, McCoy AJ, Moriarty NW, Grosse-Kunstleve RW, Afonine PV, Zwart PH \& Hung LW (2009) Decision-making in structure solution using Bayesian estimates of map quality: the PHENIX AutoSol wizard. Acta Crystallogr. D Biol. Crystallogr. 65: 582-601 
Structure-function analysis of $\mathrm{CNF}_{Y}$

Terwilliger TC, Grosse-Kunstleve RW, Afonine PV, Moriarty NW, Zwart PH, Hung LW, Read RJ \& Adams PD (2008) Iterative model building, structure refinement and density modification with the PHENIX AutoBuild wizard. Acta Crystallogr. D Biol. Crystallogr. 64: $61-69$

Tsurumura T, Tsumori Y, Qiu H, Oda M, Sakurai J, Nagahama M \& Tsuge H (2013) Arginine ADP-ribosylation mechanism based on structural snapshots of iota-toxin and actin complex. Proc. Natl. Acad. Sci. U.S.A. 110: 4267-4272

Vannini E, Olimpico F, Middei S, Ammassari-Teule M, de Graaf EL, McDonnell L, Schmidt G, Fabbri A, Fiorentini C, Baroncelli L, Costa M \& Caleo M (2016) Electrophysiology of glioma: a Rho GTPase-activating protein reduces tumor growth and spares neuron structure and function. Neuro-oncology 18: 1634-1643

Vonrhein C, Flensburg C, Keller P, Sharff A, Smart O, Paciorek W, Womack T \& Bricogne $\mathrm{G}$ (2011) Data processing and analysis with the autoPROC toolbox. Acta Crystallogr. D Biol. Crystallogr. 67: 293-302

Walker KE \& Weiss AA (1994) Characterization of the dermonecrotic toxin in members of the genus Bordetella. Infect. Immun. 62: 3817-3828

Wolters M, Boyle EC, Lardong K, Trülzsch K, Steffen A, Rottner K, Ruckdeschel K \& Aepfelbacher M (2013) Cytotoxic necrotizing factor-Y boosts Yersinia effector translocation by activating Rac protein. J. Biol. Chem. 288: 23543-23553

Zhang Z, Aung KM, Uhlin BE \& Wai SN (2018) Reversible senescence of human colon cancer cells after blockage of mitosis/cytokinesis caused by the CNF1 cyclomodulin from Escherichia coli. Sci Rep 8: 17780 
bioRxiv preprint doi: https://doi.org/10.1101/2020.04.07.029181; this version posted September 21, 2020. The copyright holder for this preprint (which was not certified by peer review) is the author/funder, who has granted bioRxiv a license to display the preprint in perpetuity. It is made available under aCC-BY-NC-ND 4.0 International license.

Structure-function analysis of $\mathrm{CNF}_{\mathrm{Y}}$

\section{Acknowledgements}

We thank the beamline staff at the Helmholtz Centre Berlin (Germany) and the Paul Scherrer Institute (Villigen, Switzerland) for providing access to beamlines BL14.1 and BL14.2 at the BESSYII electron storage ring and to beamline X06DA at the SLS synchrotron. Experiments at the SLS have received funding from the European Union's Horizon 2020 research and innovation program under grant agreement $n \cdot .^{\circ} 730872$, project CALIPSOplus. Andrea Berger and Ute Widow are acknowledged for excellent technical assistance. We thank Janina Schweer for the construction of initial plasmids and strains. Manfred Nimtz and Josef Wissing helped with mass spectrometry experiments. PD and PC received funding from the SFB1009 (Project no. 194468054) of the German Research Foundation (DFG). TH and PC were supported by the HZI Graduate School for Infection Research.

\section{Author contributions}

PD and WB conceived the project. PL, EMG and TH produced recombinant proteins and performed crystallization and structure determination. CR, PC, SM, and TS conducted work with Y. pseudotuberculosis and analyzed microscopy experiments with eukaryotic cells. Similar microscopy experiments with recombinant proteins were performed by AS, MK and SSD. WJB and LJ performed and analyzed mass-spectrometric experiments. PD, PL, and WB wrote the manuscript.

\section{Data availability}

Coordinates and structure factor amplitudes have been deposited in the Protein Data Bank with accession codes 6Q7Z (CNFY 1-704), 6Q7Y (CNFY 720-1014), $6 \mathrm{Q} 80$ (CNFY 526-1014) and 6Q7X (CNFY 1-1014 C866S).

\section{Competing interests}

The authors declare no competing interests. 

perpetuity. It is made available under aCC-BY-NC-ND 4.0 International license.

Structure-function analysis of $\mathrm{CNF}_{Y}$

\section{Figure legends}

\section{Figure 1. The crystal structure of $\mathrm{CNF}_{\mathrm{Y}}$ from Y. pseudotuberculosis.}

A Domain boundaries and sequence motifs mapped to the sequence of CNFY.

B Cartoon representation of $\mathrm{CNF}_{\mathrm{Y}}$, colored according to domain boundaries determined with PiSQRD (Aleksiev et al, 2009). Dark blue: domain D1, cyan: domain D2, dark green: domain D3, yellow: ADP-ribosyltransferase-like domain D4, pink: deamidase domain D5. Other colors indicate the position of sequence motifs that have been identified in $E$. coli CNF1, namely light blue: p37LRP/67LR receptor-binding motif, red: hydrophobic stretches predicted to form membrane-inserting $\alpha$-helices, orange: cleavage site, magenta: main Lu/BCAM receptor-binding motif. The positions of $\mathrm{N}$ - and $\mathrm{C}$-terminus are indicated by $\mathrm{N}$ and C, respectively.

C Surface representation of CNFy as seen from two different orientations with respect to B. Note that the cleavage site between D3 and D4 (orange) as well as the deamidase active site in D5 are partially blocked in the structure of full-length CNFY. The C-terminal domain D5 interacts mainly with D3 $\left(610 \AA^{2}\right)$, which partially hides the catalytic site of D5, but it interacts only weakly with D4 $\left(380 \AA^{2}\right)$, which itself establishes an extensive interface with D1 (1390 $\left.\AA^{2}\right)$ by mainly hydrophilic interactions (17 hydrogen bonds and 6 salt bridges).

Figure 2. Synthesis, secretion, and host cell binding of $\mathrm{N}$ - and $\mathrm{C}$-terminal deletion variants of $\mathrm{CNF}_{\mathbf{Y}}$.

A Schematic overview of marker-tagged $\mathrm{CNF}_{Y}$ deletion variants.

B 3xFlag-tagged CNFY deletion variants were expressed in Y. pseudotuberculosis YP147 $(\Delta c n f Y$ from plasmids under control of their own promoter and were detected in whole cell extracts using an anti-Flag antibody.

$\mathrm{C}$ To test secretion of the $\mathrm{CNF}_{\mathrm{Y}}$ variants, full-length $\mathrm{CNF}_{\mathrm{Y}}$ and different $\mathrm{N}$ - and $\mathrm{C}$-terminally deleted variants fused to beta-lactamase (TEM) were expressed in Y. pseudotuberculosis 
bioRxiv preprint doi: https://doi.org/10.1101/2020.04.07.029181; this version posted September 21, 2020. The copyright holder for this preprint (which was not certified by peer review) is the author/funder, who has granted bioRxiv a license to display the preprint in perpetuity. It is made available under aCC-BY-NC-ND 4.0 International license.

Structure-function analysis of $\mathrm{CNF}_{\mathrm{Y}}$

YP147 ( $\Delta c n f$ Y). Beta-lactamase activity in the culture supernatant was subsequently measured using nitrocefin as substrate.

D HEp-2 cells remained untreated or were incubated with $20 \mu \mathrm{g} / \mathrm{ml}$ of whole cell extract of Y. pseudotuberculosis expressing full-length $\mathrm{CNF} 1, \mathrm{CNF}_{Y}$ or the $\mathrm{N}$ - or C-terminally deleted toxin variants at $37^{\circ} \mathrm{C}$ for $4 \mathrm{~h}$. The cells were thoroughly washed, pelleted, lysed and the toxin variants bound to the cells were identified by western blotting using an anti-Flag antibody.

Figure 3. Translocation of the deletion variants of $\mathrm{CNF}_{\mathrm{Y}}$ and their influence on RhoA activation, actin rearrangements and multinucleation of host cells.

A HEp-2 cells were incubated with $20 \mu \mathrm{g} / \mathrm{ml}$ of whole cell extract of $Y$. pseudotuberculosis expressing full-length $\mathrm{CNF}_{Y}$ or the $\mathrm{N}$ - or $\mathrm{C}$-terminally deleted toxin variants fused to $\beta$ lactamase (TEM) at $37^{\circ} \mathrm{C}$ for $4 \mathrm{~h}$. Cleavage of the reporter dye CCF4-AM was used to visualize toxin delivery. After cell entry CCF4-AM is rapidly converted into the negatively charged form CCF4, which is retained in the cytosol and emits a green fluorescence signal $(520 \mathrm{~nm})$. In the presence of translocated $\beta$-lactamase fusion proteins, CCF4-AM is cleaved, and disruption of FRET results in blue fluorescence (447 nm). White bar: $20 \mu \mathrm{m}$. B Upper panels: HEp-2 cells remained untreated or were incubated with $20 \mu \mathrm{g} / \mathrm{ml}$ of whole cell extract of $Y$. pseudotuberculosis expressing full-length $\mathrm{CNF}_{Y}$ or the $\mathrm{N}$ - or C-terminally deleted toxin variants for $4 \mathrm{~h}$. Cells were lysed and the deamidation of RhoA was analyzed by the shift of the modified Rho GTPase band in SDS PAGE gels; lower panel: HEp-2 cells were lysed and the cell extracts were incubated with full-length $\mathrm{CNF}_{\mathrm{Y}}$ or the $\mathrm{N}$-terminally deleted toxin variants for $4 \mathrm{~h}$. The deamidation of RhoA in the cell extracts was analyzed by the mobility shift of the modified Rho GTPase on SDS PAGE after detection with antiRhoA antibodies.

C HEp-2 cells were incubated with $20 \mu \mathrm{g} / \mathrm{ml}$ of whole cell extract of $Y$. pseudotuberculosis expressing full-length $\mathrm{CNF}_{\mathrm{Y}}$ or the $\mathrm{N}$ - or C-terminally deleted toxin variants for $24 \mathrm{~h}$. The cell nuclei were strained with DAPI (blue) and the actin cytoskeleton was stained using 
bioRxiv preprint doi: https://doi.org/10.1101/2020.04.07.029181; this version posted September 21,2020 . The copyright holder for this preprint (which was not certified by peer review) is the author/funder, who has granted bioRxiv a license to display the preprint in perpetuity. It is made available under aCC-BY-NC-ND 4.0 International license.

Structure-function analysis of $\mathrm{CNF}_{Y}$

FITC-phalloidin (green). The formation of large, multinuclear cells was observed by fluorescence microscopy and the formation of thick actin stress fibers and membrane actin folding were only observed with $\mathrm{CNF}_{\mathrm{Y}}$-treated cells. The white scale bar is $40 \mu \mathrm{m}$. Cells incubated with extracts of YP147 ( $\Delta c n f Y$ ) harboring the empty expression vector were used as negative controls.

Figure 4. Localization of the $\mathrm{N}$ - and $\mathrm{C}$-terminal deletion variants of $\mathrm{CNF}_{\mathrm{Y}}$ in the late endosome.

HEp-2 cells were incubated with $20 \mu \mathrm{g} / \mathrm{ml}$ of whole cell extract of $Y$. pseudotuberculosis expressing full-length $\mathrm{CNF}_{\mathrm{Y}}, \mathrm{N}$ - or C-terminal deletion variants fused to GFP (green) for 90 or $180 \mathrm{~min}$. Cells were fixed and processed for fluorescence microscopy. The red fluorescent signal represents late endosomes (CellLight Late Endosomes-RFP (Rab7a)). Nuclei were stained with DAPI (blue). A merged image of the different channels is shown, and smaller images are magnified views of boxed areas. White scale bar is $10 \mu \mathrm{m}$.

Figure 5. Structural homology of the $\mathrm{CNF}_{\mathrm{Y}}$ toxin and domain organization of toxins with a CNF-like translocation apparatus.

A Side-by-side comparison of CNFy and nigritoxin. Nigritoxin is a toxin of crustaceans and insects. The translocation domain of nigritoxin (PDB entry 5M41, (Labreuche et al, 2017)) and domain $\mathrm{D} 1$ of $\mathrm{CNF}$ y show partial structural similarity (highlighted areas). This similarity was identified with DALI (Holm \& Rosenström, 2010) which was also used to align both structures.

B The ART-like domain D4 of CNFY. Essential residues of canonical ARTs are not conserved in $\mathrm{CNF}_{\mathrm{Y}}$ (RSE-ARTs exemplified by $C$. perfringens iota toxin, PDB entry $4 \mathrm{H} 03$ (Tsurumura et al, 2013); HYE-ARTs exemplified by $P$. aeruginosa ExoA, PDB entry 2ZIT (Jørgensen et al, 2008); carbon atoms of NAD+ shown in black).

C The deamidase domain D5 of CNFY. C866 and H881 form a conserved catalytic dyad also found in the deamidase domain of E. coliCNF1 (PDB entry 1HQ0, (Buetow et al, 2001)) 
Structure-function analysis of $\mathrm{CNF}_{Y}$

and Burholderia pseudomallei lethal factor BLF1 (PDB entry 3TU8, (Cruz-Migoni et al, 2011)).

Figure 6. Characterization of mutants in the linker region connecting domain D3 and D4.

A HEp-2 cells were incubated with $20 \mu \mathrm{g} / \mathrm{ml}$ of whole cell extract of $Y$. pseudotuberculosis expressing $\mathrm{CNF}_{\mathrm{Y}}$, the toxin variant mut1: CNFYl535L/P536A/V537G or mut2: CNFY1535L/P536A/V537G/F539L/D541A/K542A fused to TEM or no CNFY protein (empty vector) for $4 \mathrm{~h}$. Cells were lysed and the binding of the different CNFY proteins to HEp-2 cells was analyzed by immunoblotting.

B HEp-2 cells were incubated with $20 \mu \mathrm{g} / \mathrm{ml}$ of whole cell extract of $Y$. pseudotuberculosis expressing $\mathrm{CNF}_{\mathrm{Y}}$, the toxin variant mut1: CNFYl535L/P536A/V537G or mut2: CNFY1535L/P536A/V537G/F539L/D541A/K542A or no CNFY protein (empty vector). The cell nuclei were stained with DAPI (blue) and the actin cytoskeleton was stained using FITCphalloidin (green). The results indicated the formation of polynucleated cells and stress fibers only in cells treated with $\mathrm{CNF}_{\mathrm{Y}}$ and $\mathrm{CNF}_{\mathrm{Y}}$ I535L/P536/V537G. The white scale bar is $20 \mu \mathrm{m}$.

C Nitrocefin (2 mM) was added to the supernatant from $25^{\circ} \mathrm{C}$ overnight Yersinia cultures expressing the indicated $\mathrm{CNF}_{\mathrm{Y}}$ derivatives to determine $\beta$-lactamase activity by measuring changes in absorbance at $390 \mathrm{~nm}$ (yellow) and $486 \mathrm{~nm}$ (red).

D The viability of $Y$. pseudotuberculosis YPIII expressing the indicated $\mathrm{CNF}_{\mathrm{Y}}$ derivatives was assessed in equalized bacterial cultures using the BacTiter-Glo Microbial Cell Viability Assay kit (Promega).

E HEp-2 cells treated with $20 \mu \mathrm{g} / \mathrm{ml}$ of whole cell extract of $Y$. pseudotuberculosis expressing indicated $\mathrm{CNF}_{\mathrm{Y}}$ variants for $4 \mathrm{~h}$ were lysed and the deamidation of RhoA was analyzed by the mobility shift of the modified RhoA GTPase detected by immunoblotting.

F The activity of the $\mathrm{CNF}_{\mathrm{Y}}$ derivatives was tested by analyzing the deamidation of RhoA in HEp-2 cell lysates by the mobility shift of the modified GTPase detected by immunoblotting. 
Structure-function analysis of $\mathrm{CNF}_{Y}$

\section{Figure 7. Structure and deamidation activity of the free D4-5 subunit of CNFy.}

A Crystal structure of the free D4-5 subunit. Note the different relative orientations of domains D4 and D5 with respect to the structure of full-length CNFY (top, thin grey lines). The domain D4 forms a large interface area $\left(1100 \AA^{2}\right)$ with the catalytic domain D5 involving several polar interactions ( 8 hydrogen bonds and 8 salt bridges), whereby the active crevice is extended and fully solvent-exposed as can be seen in the right surface plot at the bottom of the panel. The hypothetical NAD+ binding site of the ART-like D4 domain is located on the opposite face (left surface plot). Note that the deamidase active site of domain D5, unlike in the full-length structure (Fig 1), is fully accessible and that its extended shape is also determined by domain D4.

B Comparative analysis of RhoA activation in HEp-2 cell lysate by $\mathrm{CNF}_{Y}$ and the recombinant D4-5 protein. Purified CNFY or the D4-5 fragment $(1 \mu \mathrm{M})$ was added to extracts of HEp-2 cells and incubated for $10,20,30$ or 60 min. Deamidation of RhoA was analyzed by the shift of the modified Rho GTPase band in SDS PAGE gels after detection with antiRhoA antibodies.

C Comparative analysis of recombinant RhoA deamidation by $\mathrm{CNF}_{\mathrm{Y}}$ and the D4-5 fragment. Recombinant RhoA was incubated with purified CNFY or the D4-5 fragment and samples were separated by SDS-PAGE after the indicated times before subjecting to trypsin digestion and quantification of deamidation of Q63 by mass spectrometry. Error bars represent standard deviations of triplicate measurements.

\section{Figure 8. Architecture of bacterial toxins with a CNF-like translocation apparatus}

Shown are the architecture of $\mathrm{CNF}_{\mathrm{Y}}$, Pasteurella multocida toxin PMT and two uncharacterized proteins from Pseudomonas syringiae. The released fragment of PMT contains three domains of which $\mathrm{C} 1$ is required for membrane binding, the $\mathrm{C} 2$ domain has an unknown function and the C3-domain activates heterotrimeric G-proteins by deamidation. The two Pseudomonas syringiae proteins A0A0P9UH04 and A0A0N8SZE6 
bioRxiv preprint doi: https://doi.org/10.1101/2020.04.07.029181; this version posted September 21, 2020. The copyright holder for this preprint (which was not certified by peer review) is the author/funder, who has granted bioRxiv a license to display the preprint in perpetuity. It is made available under aCC-BY-NC-ND 4.0 International license.

Structure-function analysis of $\mathrm{CNF}_{\mathrm{Y}}$

represent two uncharacterized toxins that encode catalytic domains of the indicated type.

While sequence alignments unequivocally reveal a CNF-like imperfect $\beta$-barrel in PMT, the presence of this domain in the $P$. syringiae toxins is less obvious. 


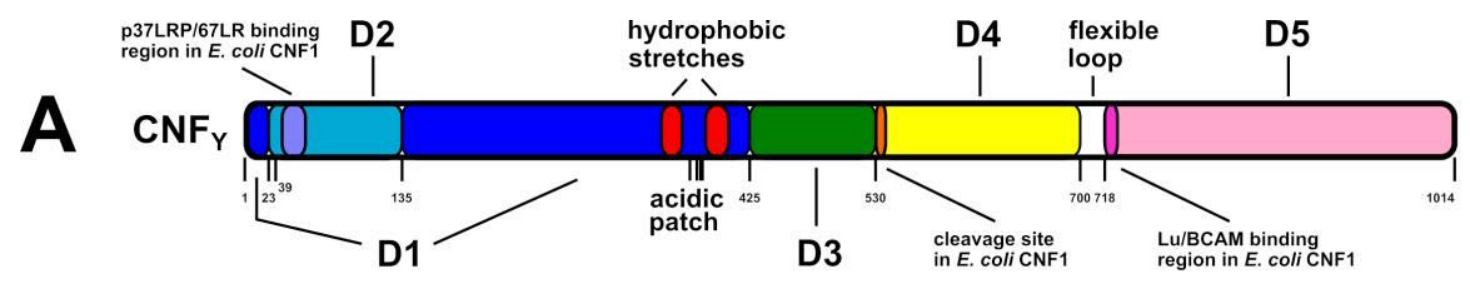

B



Figure 1 
A

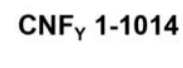

N

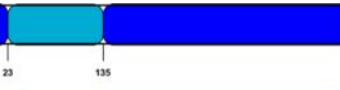

$\mathrm{CNF}_{\mathrm{Y}} \Delta \mathbf{\Delta 9 - 1 3 4}$

No

,

$\mathrm{CNF}_{\mathrm{Y}} \Delta 134-426 \mathrm{~N}$
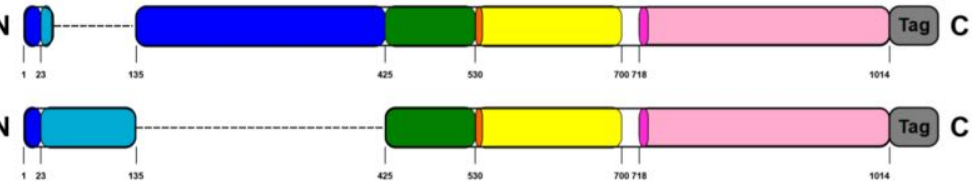

CNFY $134-426$ N



$\mathrm{CNF}_{\mathrm{Y}} \Delta 39-426$

$\mathbf{N} \prod_{n}$



CNF $_{Y} 1-719$

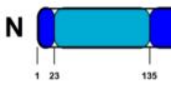

Tag C

$\mathrm{CNF}_{\mathrm{Y}} 1-526$

CNF $_{Y}$ 1-443

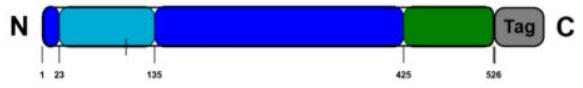

$\mathrm{CNF}_{\mathrm{Y}} 1-443$

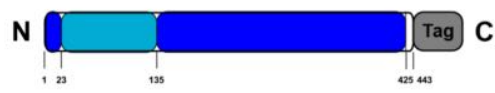

B
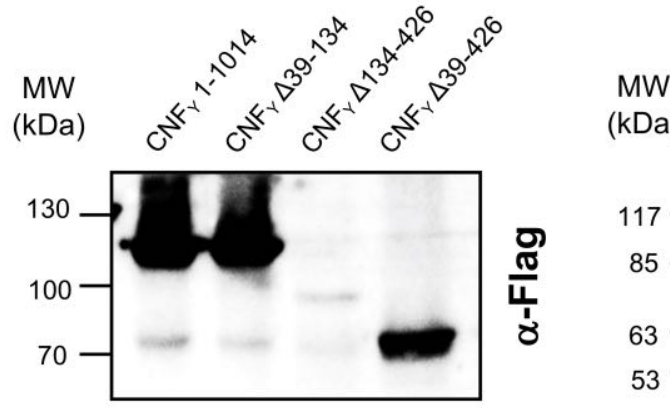

(kDa)

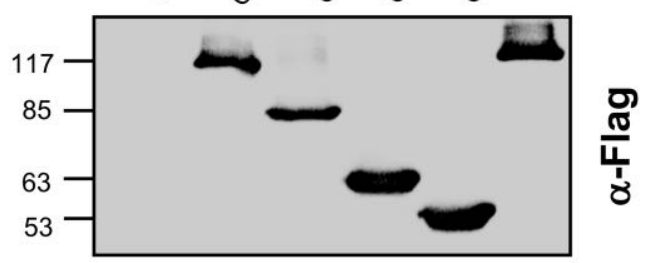

C

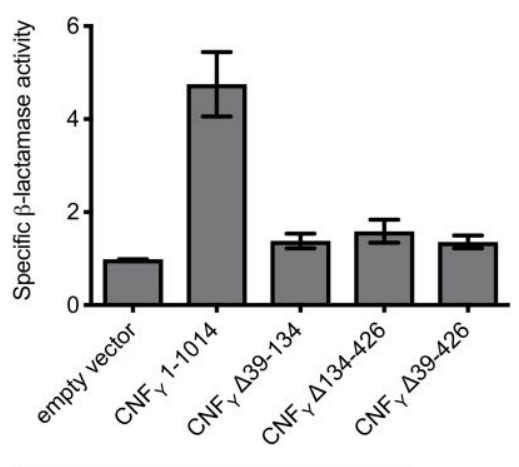

YP147( $\Delta c n f Y)$


YP147( $\Delta c n f Y)$

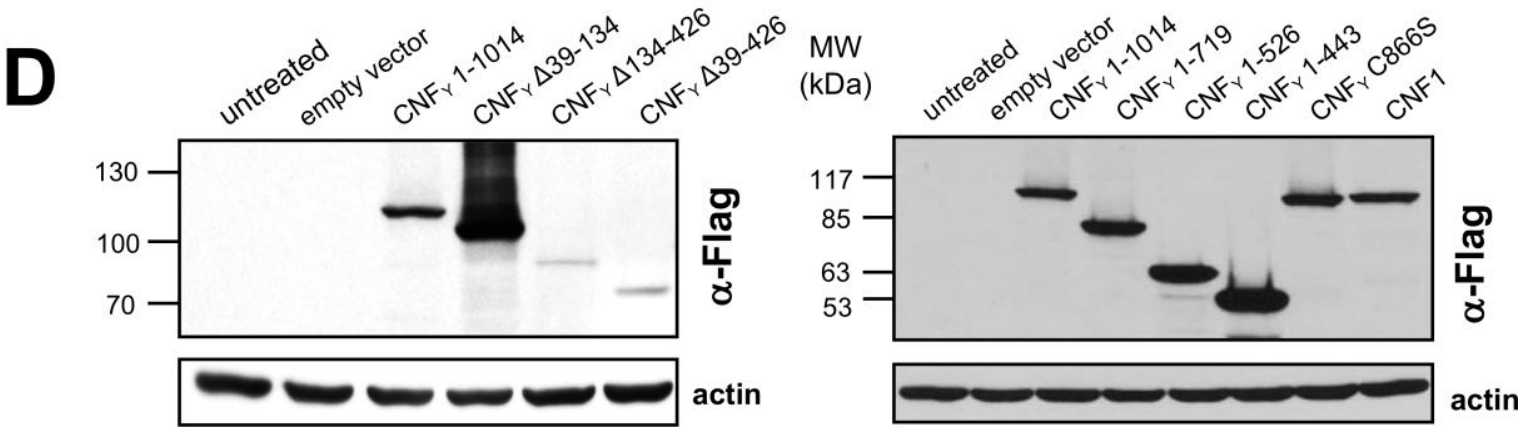

Figure 2 
A
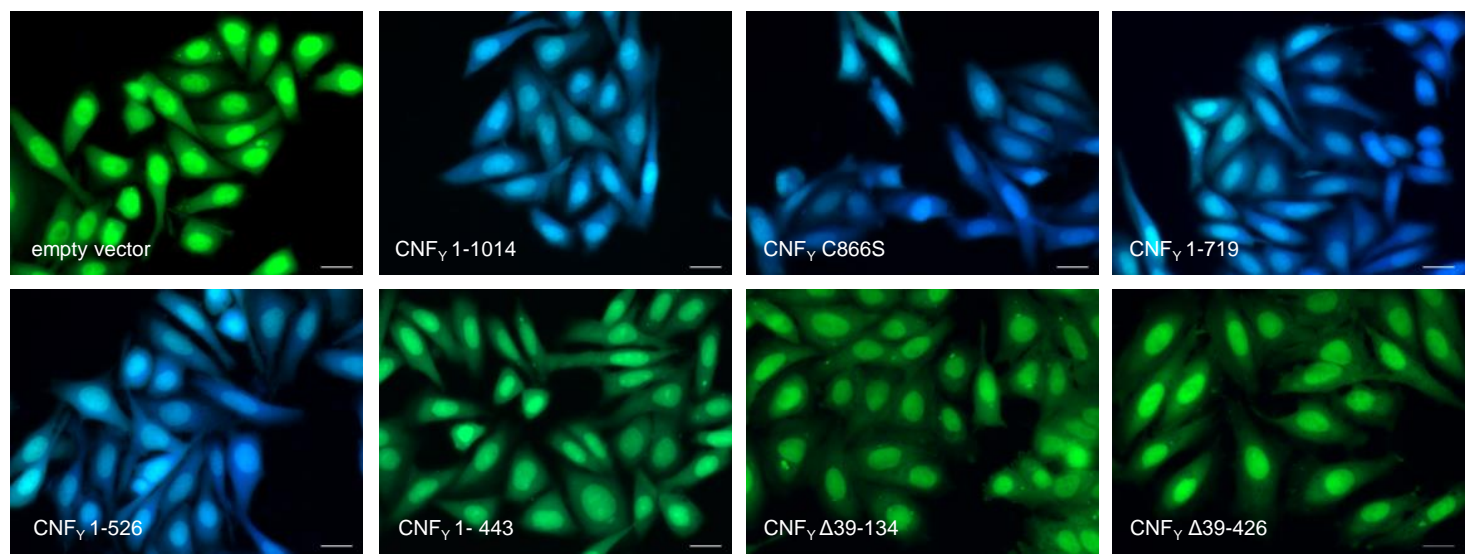

B
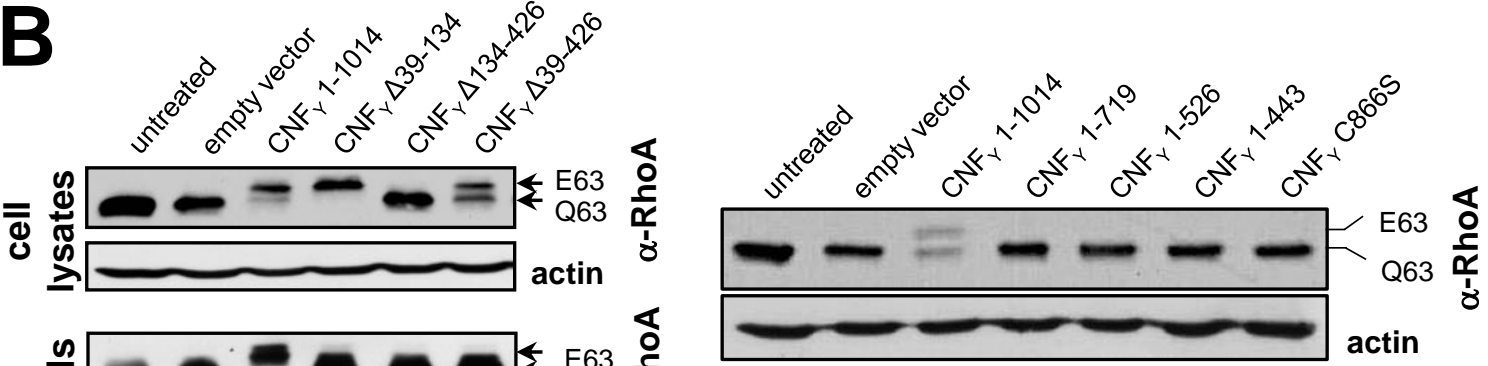

C
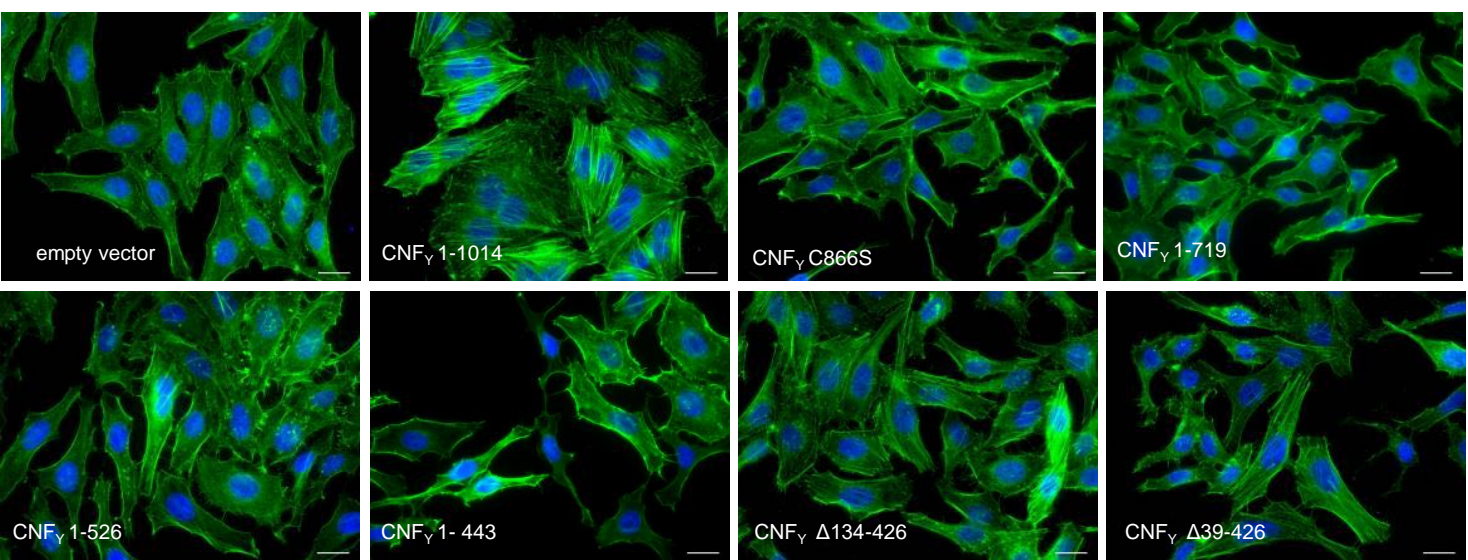

Figure 3 


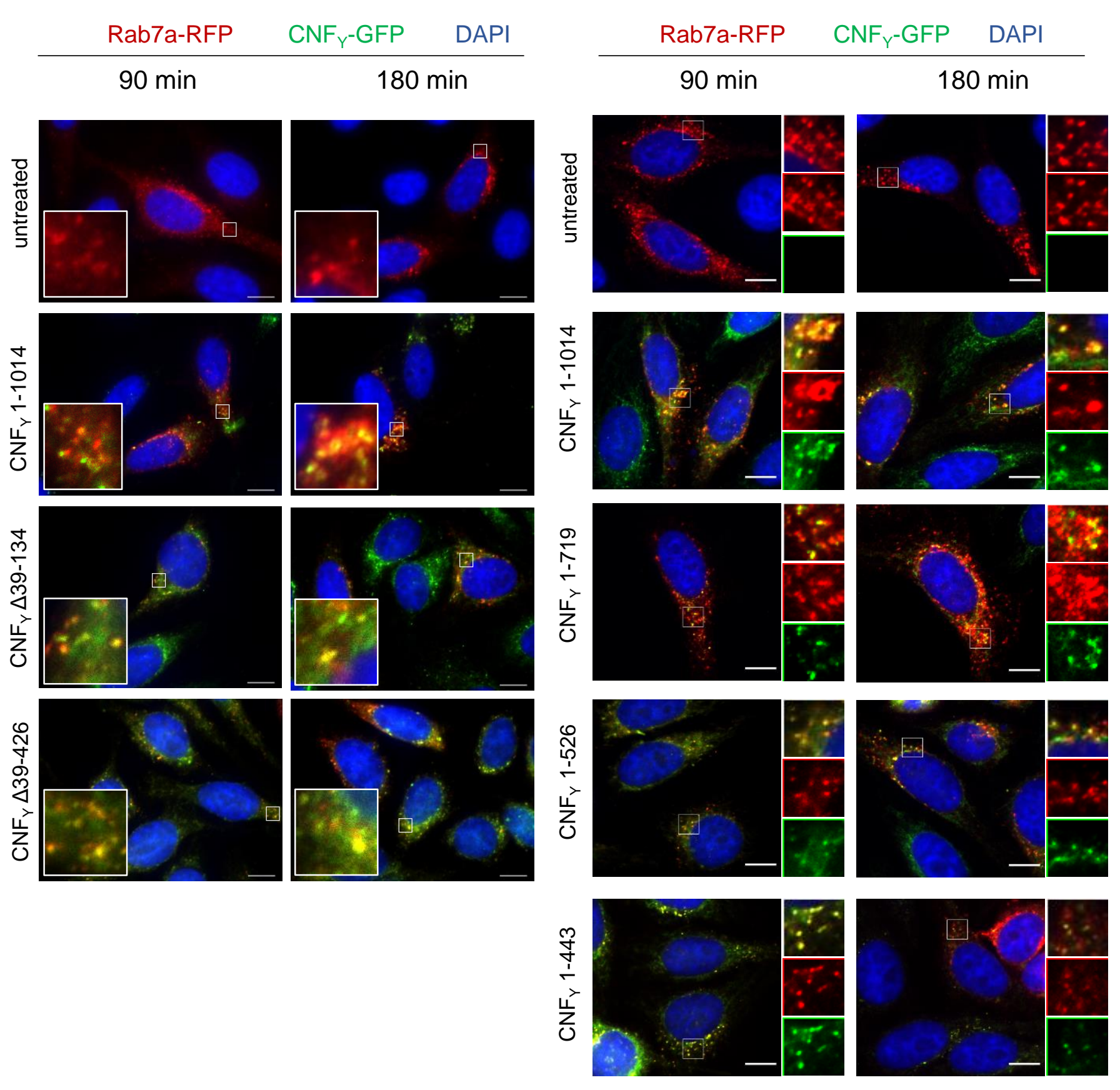

Figure 4 
A

$\mathrm{CNF}_{\mathrm{Y}}$

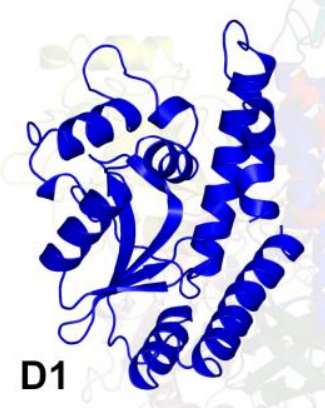

nigritoxin

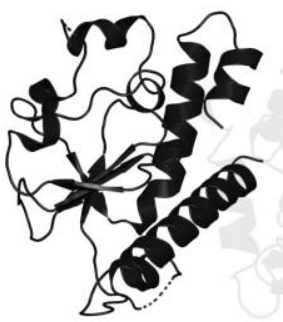

$5 M 41$

translocation domain

B

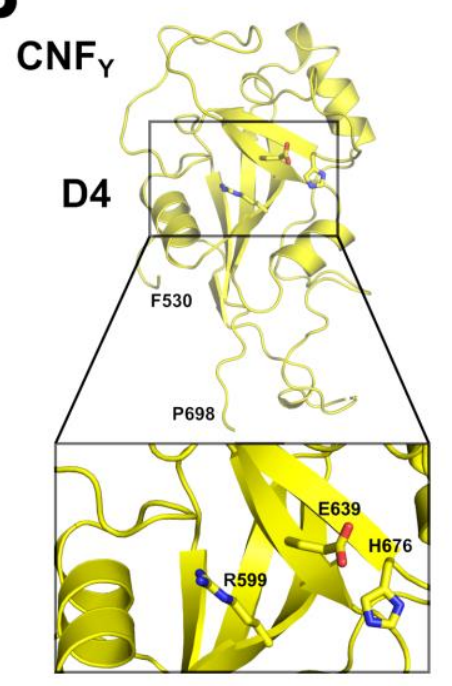

C

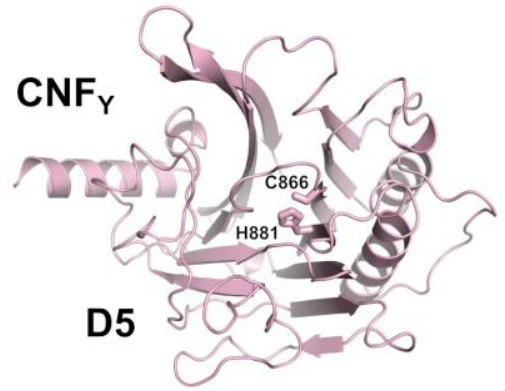

C. perfingens iota toxin

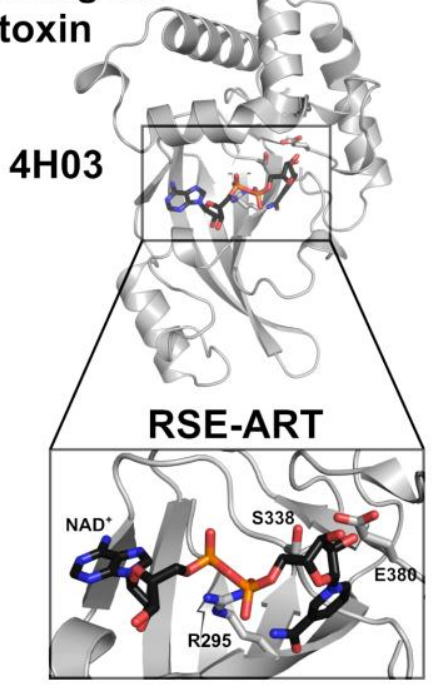

E. coli CNF1

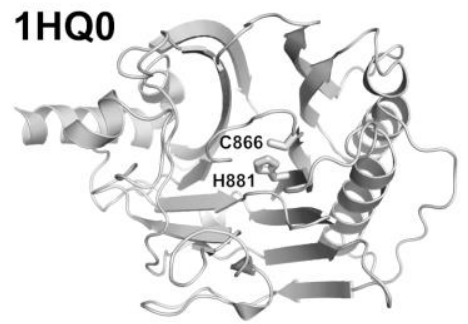

$P$. aeruginosa ExoA

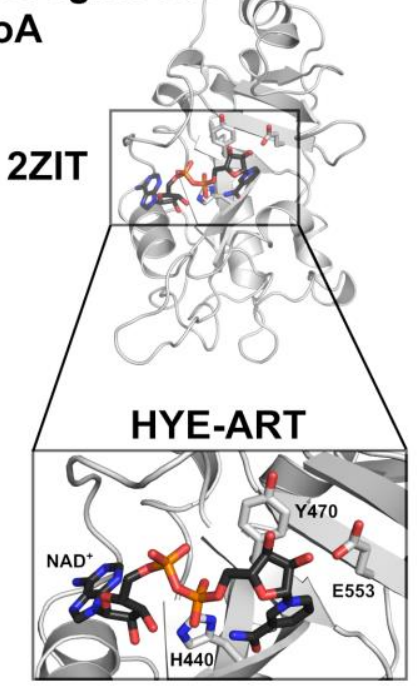

B. pseudomallei BLF1

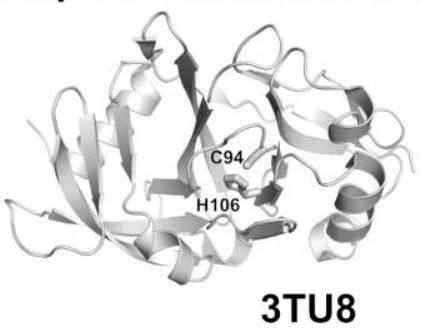


A

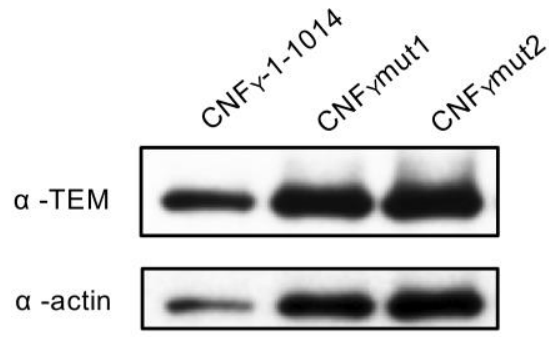

C
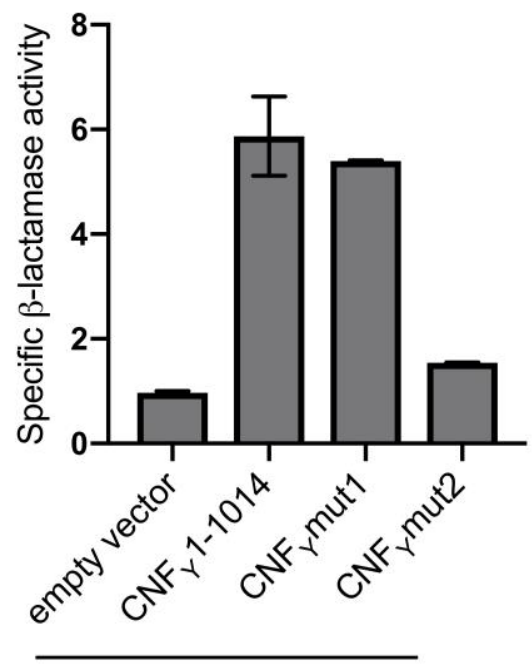

YP147( $\Delta c n f Y)$

트

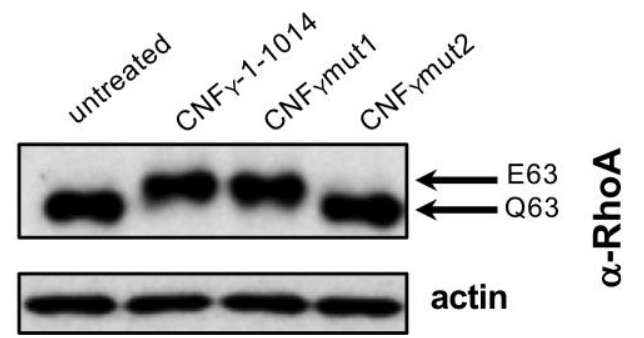

$\mathbf{F}$
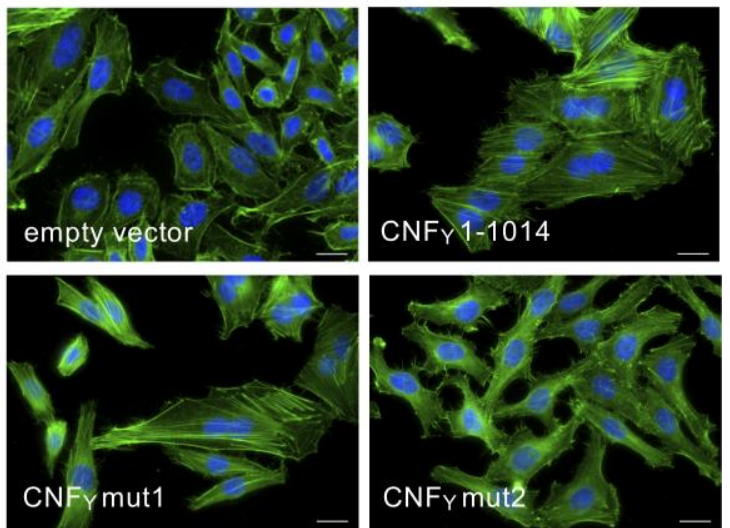

D
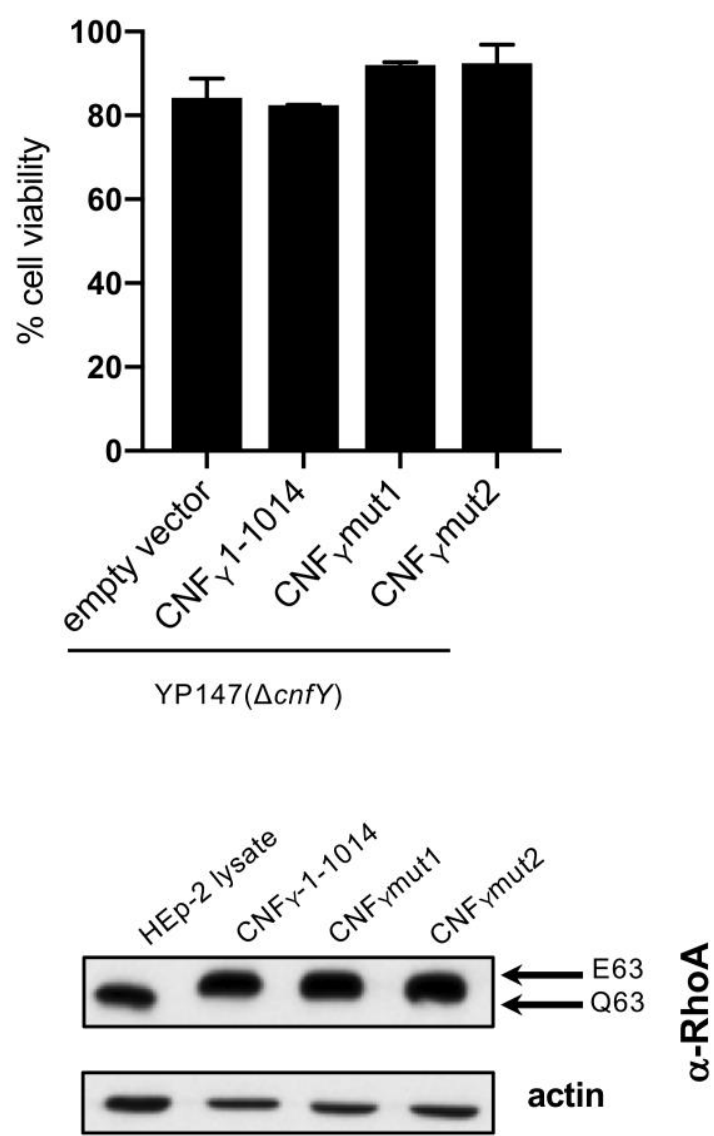

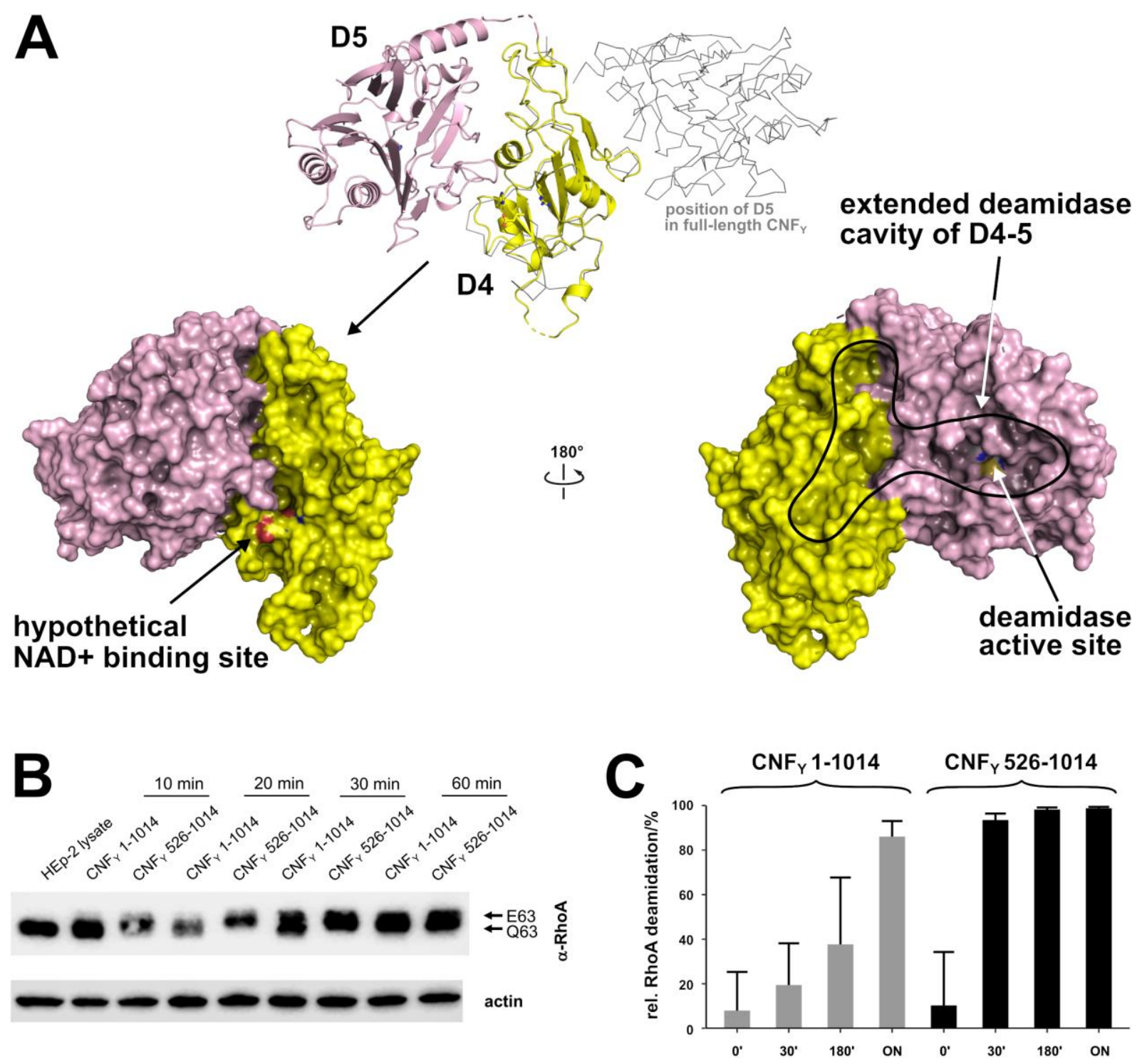


\begin{tabular}{|l|l|l|}
\hline D4 & D5 \\
\hline
\end{tabular}

Pasteurella multocida PMT

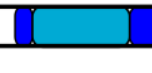

C1

AOAOP9UH04

A0A0N8SZE6 \begin{tabular}{c|c|c|c|}
\hline & glucosyl transferase & Pseudomonas syringiae \\
pv. syringiae
\end{tabular}




\section{Expanded View Tables}

Table EV1. X-ray data collection and refinement statistics.

\begin{tabular}{|c|c|c|c|c|c|}
\hline $\begin{array}{l}\text { Structure } \\
\text { PDB-ID: }\end{array}$ & $\begin{array}{l}\text { CNF } 1-704 \text { SeMet } \\
-\end{array}$ & $\begin{array}{l}\text { CNF }_{Y} 1-704 \text { nat } \\
6 Q 7 Z\end{array}$ & $\begin{array}{l}\text { CNF }_{Y} 720-1014 \\
6 Q 7 Y\end{array}$ & $\begin{array}{l}\text { CNF }_{Y} 526-1014 \\
6 Q 80\end{array}$ & $\begin{array}{l}\text { CNFY full-length (C866S) } \\
\text { 6Q7X }\end{array}$ \\
\hline \multicolumn{6}{|l|}{ Data collection } \\
\hline Beamline & BESSY BL 14.1 & SLS X06DA (PXIII) & BESSY BL 14.2 & SLS X06DA (PXIII) & SLS X06DA (PXIII) \\
\hline Wavelength $(\AA ̊)$ & 0.98 & 1.00 & 0.92 & 1.00 & 1.00 \\
\hline Space group & $\mathrm{P} 2_{1}$ & $\mathrm{P} 2_{1}$ & $\mathrm{P} 2_{1}$ & $\mathrm{P} 22_{1} 2_{1} 2_{1}$ & $122_{1} 2_{1}$ \\
\hline \multicolumn{6}{|l|}{ Cell dimensions } \\
\hline$a, b, c(\AA)$ & $94.26,99.70,131.06$ & $94.43,99.90,131.36$ & $41.98,50.16,69.73$ & $48.27,90.53,120.72$ & $70.15,180.42,220.76$ \\
\hline$\alpha, \beta, \gamma\left({ }^{\circ}\right)$ & $90.00,95.85,90.00$ & $90.00,95.86,90.00$ & $90.00,98.72,90.00$ & $90.00,90.00,90.00$ & $90.00,90.00,90.00$ \\
\hline Resolution $(\AA)^{a}$ & $49.01-3.8(4.06-3.8)$ & $99.90-3.28(3.33-3.28)$ & $68.92-1.14(1.15-1.14)$ & $48.27-1.80(1.84-1.80)$ & $47.08-2.70(2.82-2.70)$ \\
\hline$R_{\text {merge }}(\%)^{\mathrm{a}}$ & $21.3(68.9)$ & $8.8(90.1)$ & $3.6(43.8)$ & $25.7(350.6)$ & $10.6(180.5)$ \\
\hline$R_{\text {pim }}(\%)^{\mathrm{a}}$ & $5.9(18.7)$ & $3.6(36.2)$ & $2.4(29.5)$ & $4.6(81.5)$ & $2.3(39.2)$ \\
\hline$\|\left.\sigma\right|^{a}$ & $13.0(4.7)$ & $17.8(2.2)$ & $16.0(2.2)$ & $12.4(1.6)$ & $23.3(2.2)$ \\
\hline Completeness (\%) ${ }^{\mathrm{a}}$ & $100.0(100.0)$ & $99.9(100.0)$ & $95.2(99.7)$ & $99.9(98.6)$ & $99.9(99.5)$ \\
\hline Redundancy ${ }^{\mathrm{a}}$ & $13.8(14.5)$ anomalous: 7.0 (7.3) & $6.9(7.1)$ & $3.0(2.9)$ & $32.7(19.8)$ & $21.4(22.0)$ \\
\hline $\mathrm{CC}_{1 / 2}(\%)^{\mathrm{a}}$ & $99.7(93.6)$ & $99.9(77.4)$ & $99.9(88.2)$ & $98.2(81.6)$ & $100(76.1)$ \\
\hline \multicolumn{6}{|l|}{ Refinement } \\
\hline Resolution (Å) & 3.8 & 3.28 & 1.14 & 1.80 & 2.70 \\
\hline No. reflections & 24050 & 37535 & 100644 & 49821 & 38988 \\
\hline$R_{\text {work }} R_{\text {free }}(\%)$ & & $24.05 / 26.46$ & $16.74 / 18.22$ & $15.81 / 19.10$ & $20.48 / 24.19$ \\
\hline No. atoms & & 12248 & 3084 & 4532 & 8847 \\
\hline Protein & & 12248 & 2745 & 4147 & 8745 \\
\hline Ligand/ion & & 0 & 1 & 18 & 46 \\
\hline Water & & 0 & 338 & 367 & 56 \\
\hline B-factors $\left(\AA^{2}\right)$ & & 95.89 & 19.59 & 35.07 & 86.94 \\
\hline Protein & & 95.89 & 18.65 & 34.28 & 86.99 \\
\hline Ligand/ion & & - & 21.19 & 70.13 & 101.15 \\
\hline Water & & - & 27.21 & 42.28 & 67.60 \\
\hline \multicolumn{6}{|l|}{ R.m.s deviations } \\
\hline Bond lengths $(\AA)$ & & 0.003 & 0.010 & 0.004 & 0.03 \\
\hline Bond angles (ํ) & & 0.608 & 1.123 & 0.676 & 0.578 \\
\hline \multicolumn{6}{|c|}{ Ramachandran statistics (\%) } \\
\hline Favored & & 95.10 & 97.23 & 97.76 & 96.35 \\
\hline Allowed & & 4.39 & 2.77 & 2.24 & 3.65 \\
\hline Outliers & & 0.50 & 0.00 & 0.00 & 0.00 \\
\hline
\end{tabular}


aValues for the highest resolution shell are shown in parentheses. 


\section{Expanded View Figures}
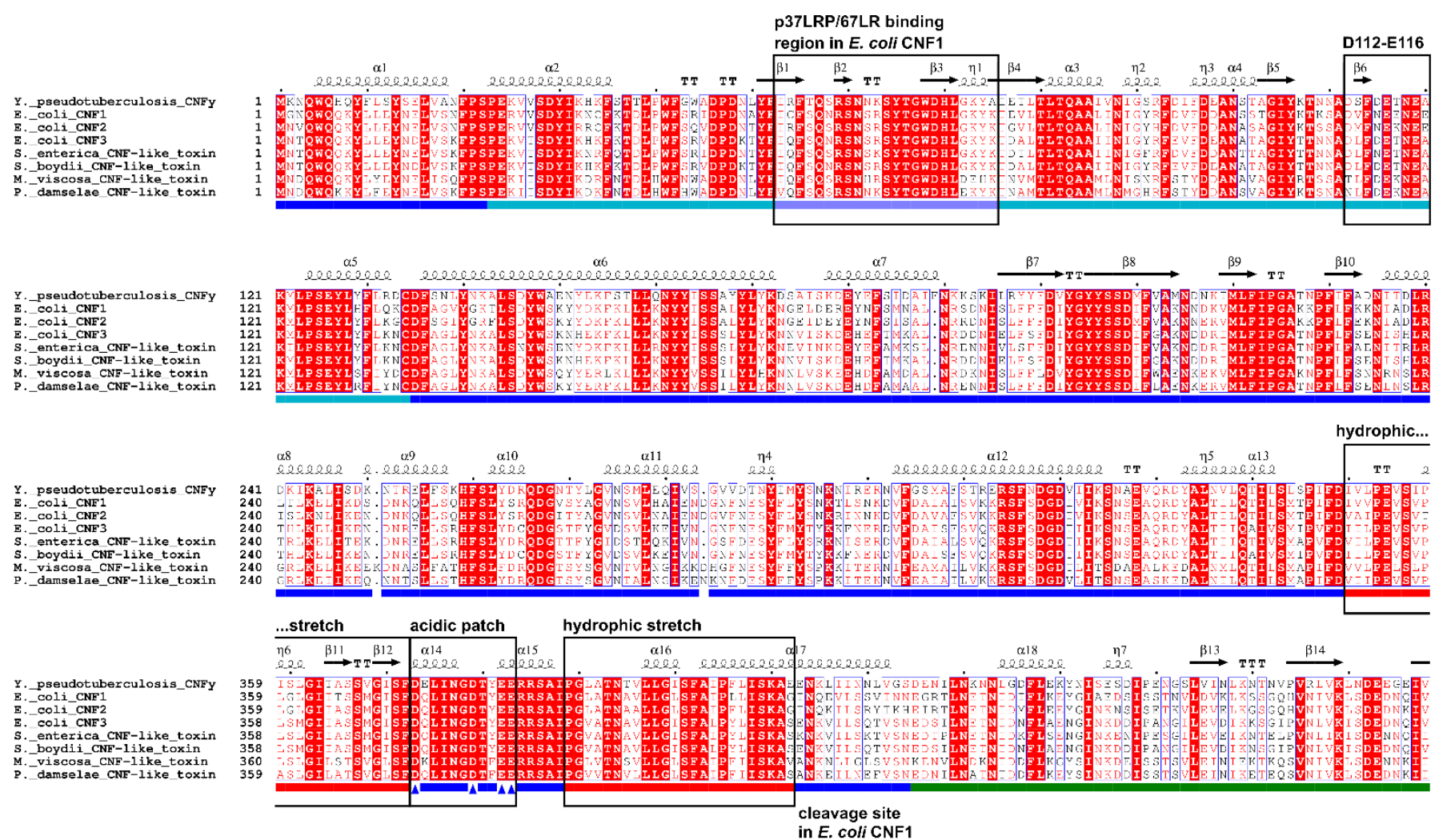

P. damselae CNF-1ike toxin

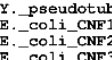

enterica CNF-1ike toxin

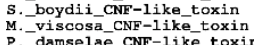

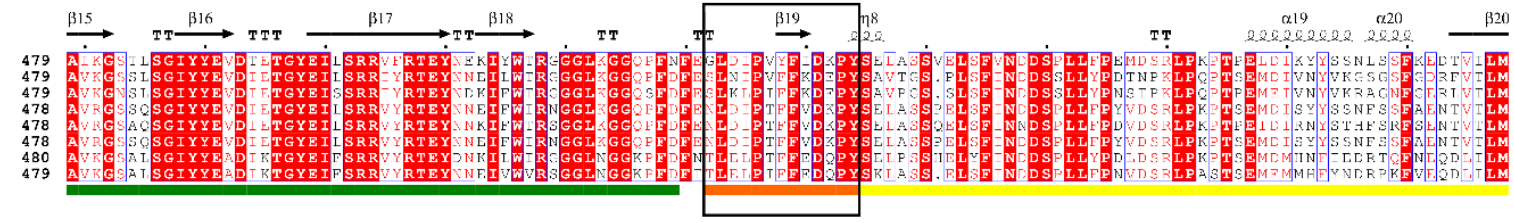

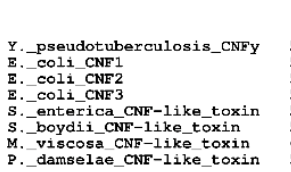
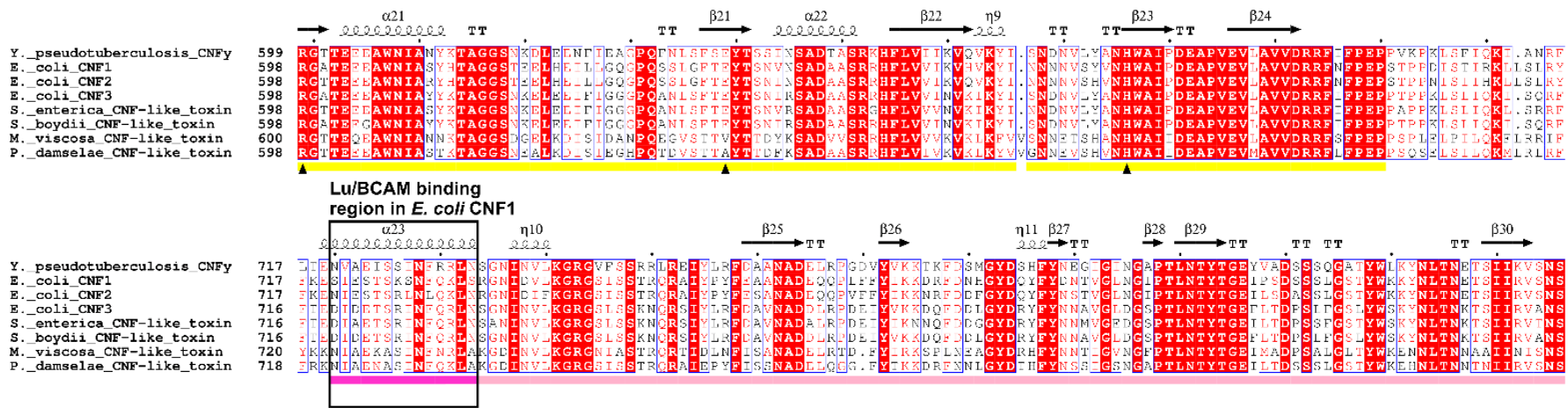

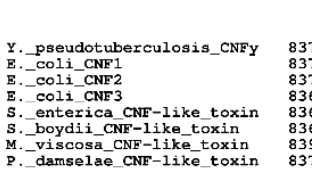
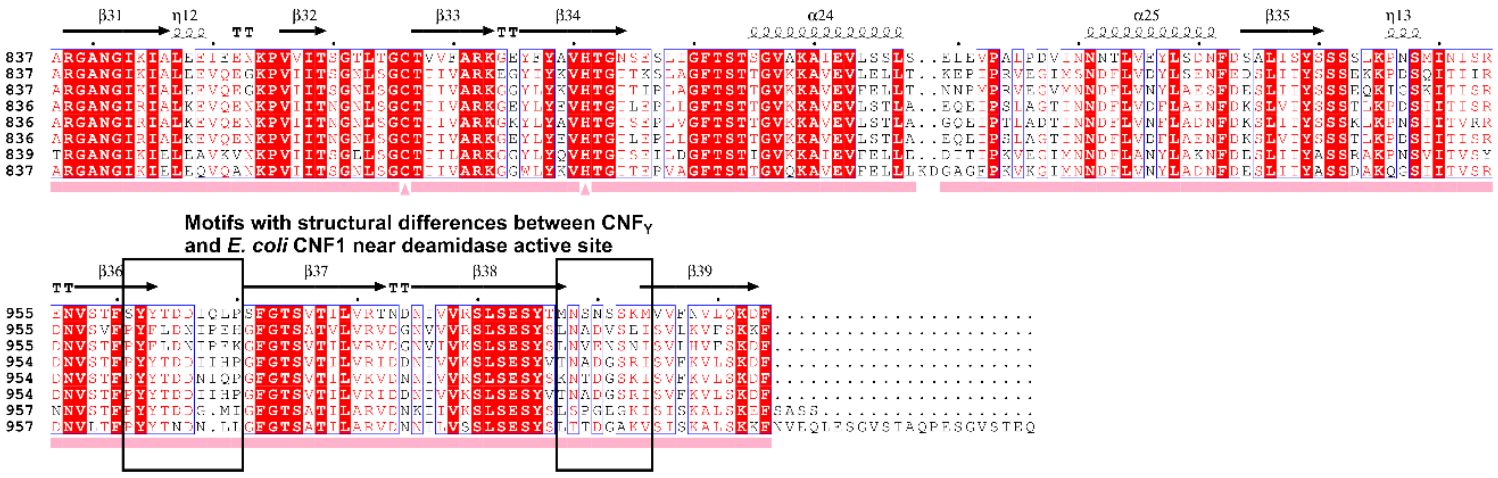
bioRxiv preprint doi: https://doi.org/10.1101/2020.04.07.029181; this version posted September 21, 2020. The copyright holder for this preprint (which was not certified by peer review) is the author/funder, who has granted bioRxiv a license to display the preprint in perpetuity. It is made available under aCC-BY-NC-ND 4.0 International license.

\section{Figure EV1. Sequence alignment of $\mathrm{CNF}_{\mathrm{Y}}$ to other CNFs.}

Sequences from top to bottom: 1. CNFy from Yersinia pseudotuberculosis, 2. CNF1 from E. coli (NCBI accession: AAA85196, 61\% sequence identity to CNFY), 3. CNF2 from E. coli (NCBI accession: ACT33566, 61\% sequence identity), 4. CNF3 from E. coli (NCBI accession: CAK19001, 68\% sequence identity), 5. CNF from Salmonella enterica (NCBI accession: WP_079946821, 69\% sequence identity), 6. CNF from Shigella boydii (NCBI accession: WP_075330563, 68\% sequence identity), 7. CNF from Moritella viscosa (NCBI accession: AHI58923, 58\% sequence identity). 8. CNF from Photobacterium damselae (NCBI accession: WP_005306733, 58\% sequence identity).

Columns with identical residues are highlighted in red. The sequence alignment was generated using ClustalX (Larkin, Blackshields et al., 2007) and formatted using the ESPript 3 webservice (Robert \& Gouet, 2014). The alignment has been annotated with the secondary structure extracted from the structural model of full-length CNFY. The domains of CNFY are indicated below the sequences using the coloring scheme used in Fig. 1. Specific residues that are supposed to be functionally relevant are marked by arrows in the domain annotation. 


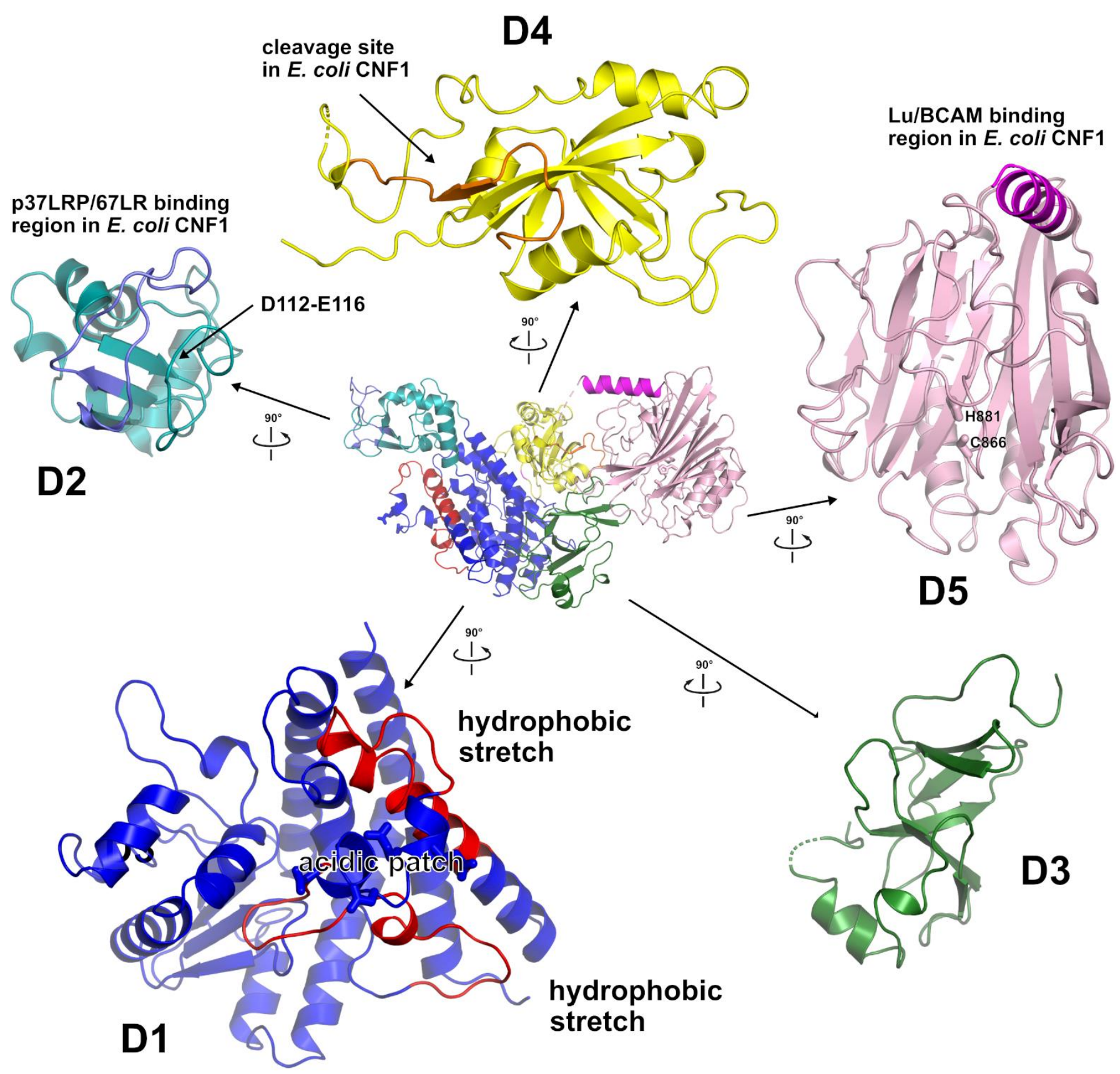

Figure EV2. Exploded view of CNFY.

Cartoon representation of full-length $\mathrm{CNF}_{\mathrm{Y}}$ (middle) surrounded by enlarged perpendicular views of the individual domains D1 to D5, colored according to domain boundaries determined with PiSQRD (Aleksiev et al, 2009). Dark blue: domain D1, cyan: domain D2, dark green: domain D3, yellow: ADP-ribosyltransferase-like domain D4, pink: deamidase domain D5. Other colors indicate the position of sequence motifs that have been identified in $E$. coli CNF1, namely light purple: p37LRP/67LR receptor-binding motif, red: hydrophobic stretches predicted to form membrane-inserting $\alpha$-helices, orange: cleavage site, magenta: main Lu/BCAM receptor-binding motif. 


\section{A}

CNFY DUF4765

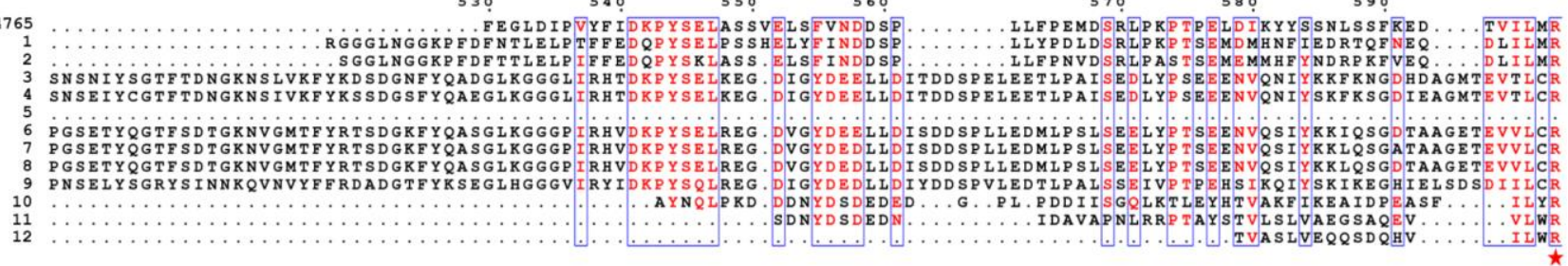

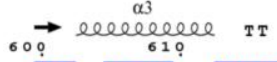

CNFY DUF4765 GTTEEEAWNIANYTTAGGS 1 GTTEQEAWNIANNITAGGSD

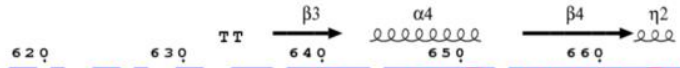
72 670

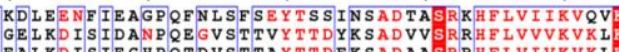

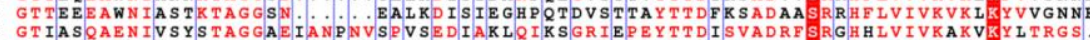
GTIASQAENIVSYSTAGGAEIANPNVNPVSDIAKL QIKSGRIEPEYTTDISVADRFSRGHLVIVKVRV

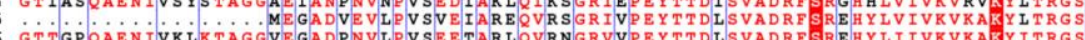
GTTGP RAENIVKLKTAGGVEGADPNVLPVSETARLQVRNGRVVPEYTTDISVADRF SREHYLIIVRVKA GTTGP REN VKLKTAGGVEGADPNVL 作 10 GVSSKTAFD MYKNSSAGGEP. ANID SP P PTTENARR RVGKGAYLPEFSVDESVFDRF SRNRYGVVVKIKSKYLSLGS 11 GTILSRALAMESNGSAGGAA. SNAGVAAPER TASRR RVGHGRLPETTARE GVAESFSTGGALVVTRIAAKYLTPGS...

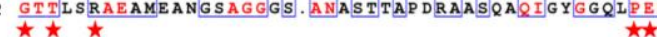

B

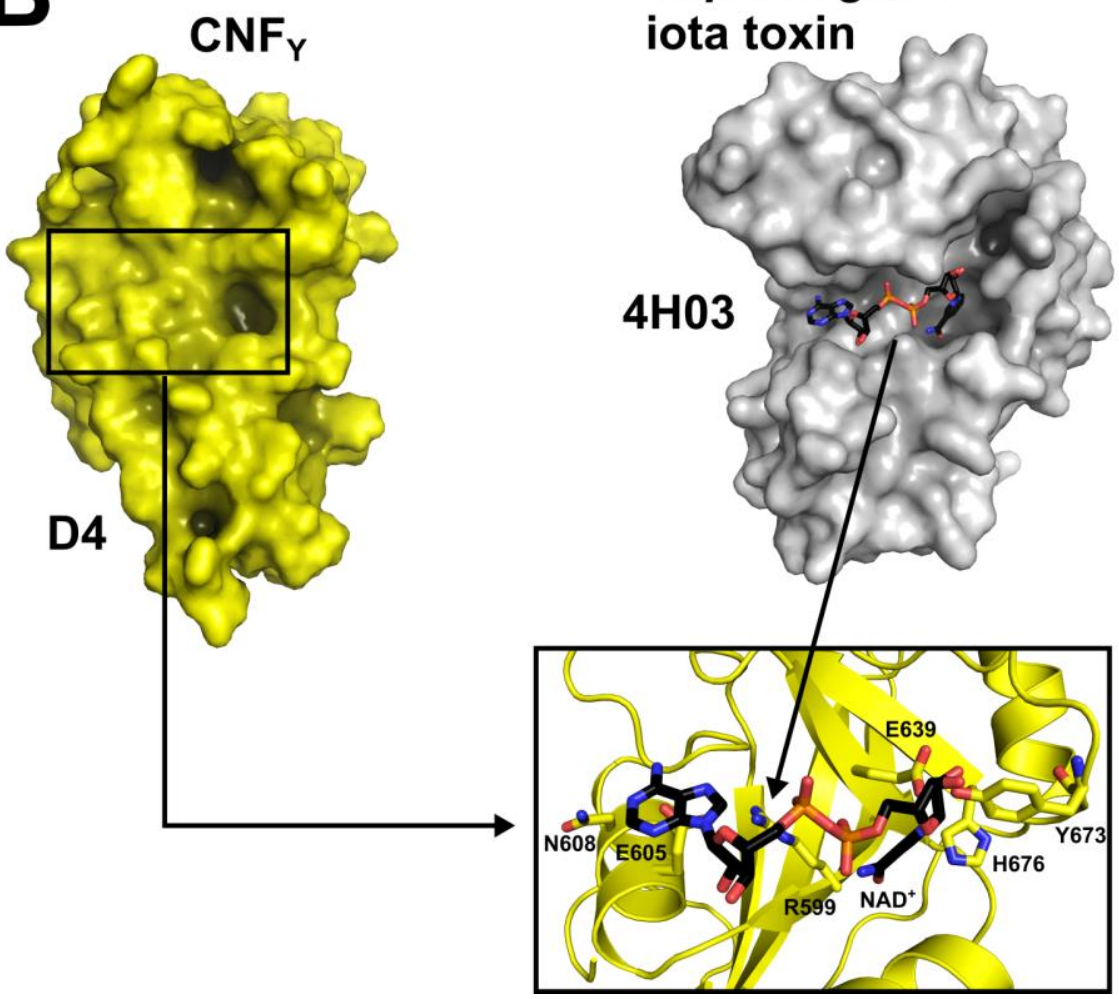

C. perfingens ota toxin

Figure EV3. Exploded view of CNFY.

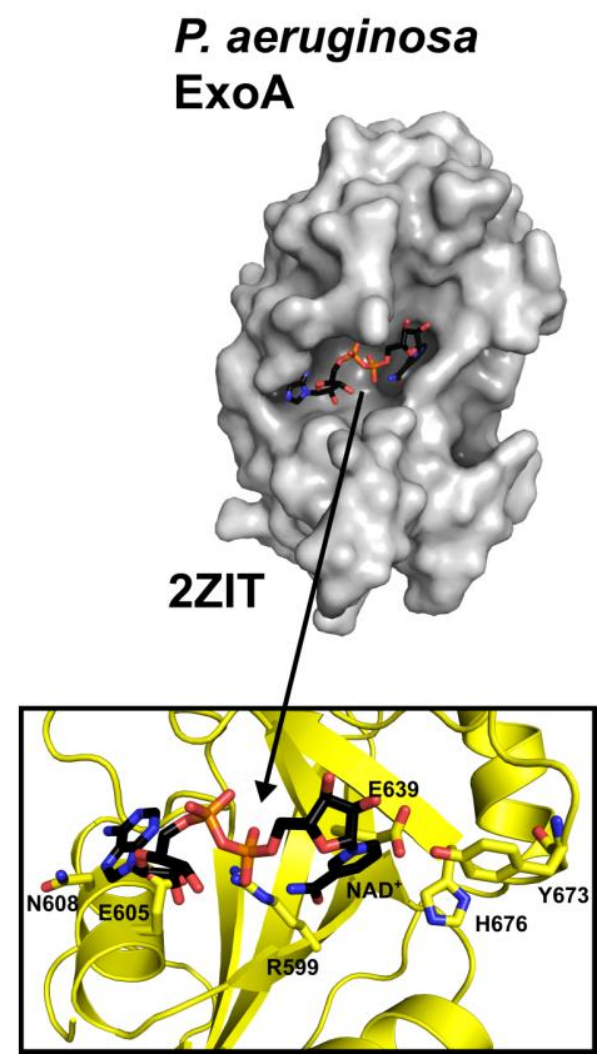

Cartoon representation of full-length $\mathrm{CNF}_{\mathrm{Y}}$ (middle) surrounded by enlarged perpendicular views of the individual domains D1 to D5, colored according to domain boundaries determined with PiSQRD (Aleksiev et al, 2009). Dark blue: domain D1, cyan: domain D2, dark green: domain D3, yellow: ADP-ribosyltransferase-like domain D4, pink: deamidase domain D5. Other colors indicate the position of sequence motifs that have been identified in $E$. coli CNF1, namely light purple: p37LRP/67LR receptor-binding motif, red: hydrophobic stretches predicted to form membrane-inserting $\alpha$-helices, orange: cleavage site, magenta: main Lu/BCAM receptor-binding motif. 
A

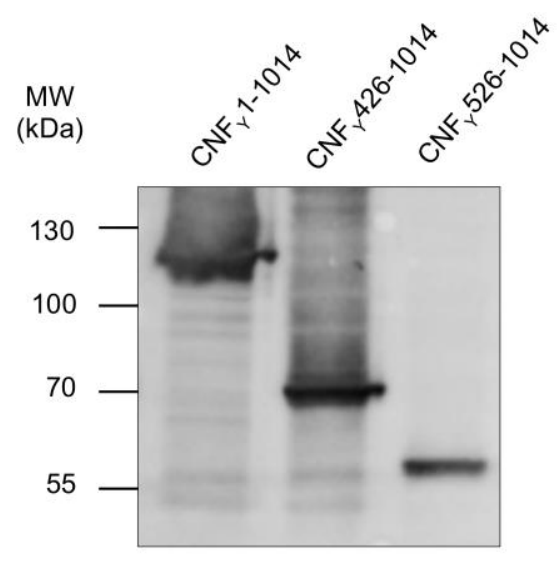

B
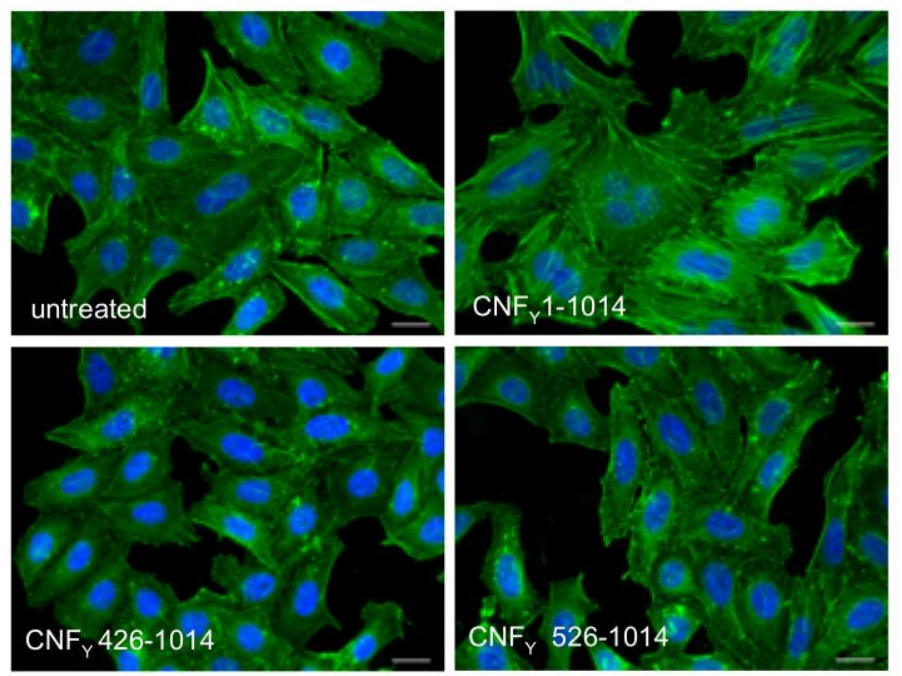
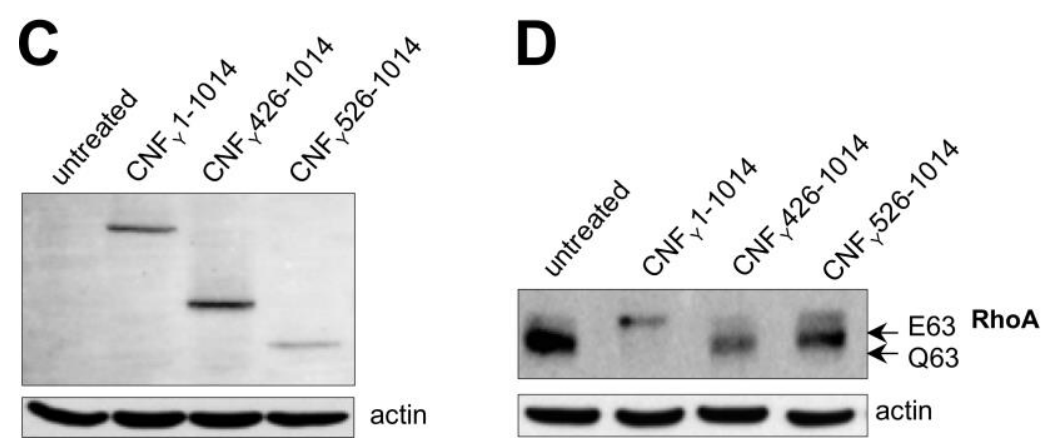

E

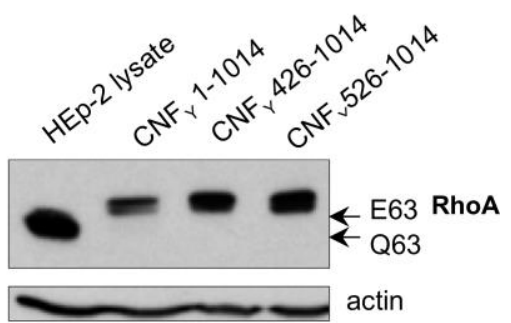

Figure EV4. C-terminal domain D3-5 and D4-5 are able to bind to host cells and deaminate RhoA. A The expression of purified recombinant CNFY N-terminal domains D3-5 (CNFY 426-1014) or D4-5 (CNFY 5261014).

B HEp-2 cells remain untreated or were incubated with $500 \mathrm{nM}$ purified full-length CNFY, domains D3-5 (CNFY 426-1014) or D4-5 (CNFY 526-1014) for $24 \mathrm{~h}$. The formation of large, multinuclear cells was observed by fluorescence microscopy. The cell nuclei were strained with DAPI (blue) and the actin cytoskeleton was stained using FITC-Phalloidin (green). The white scale bar is $20 \mu \mathrm{m}$.

C Binding of purified full-length CNFY, domains D3-5 (CNFY 426-1014) or D4-5 (CNFY 526-1014) to HEp-2 cells was analyzed by immunoblotting after HEp-2 cells were incubated with $500 \mathrm{nM}$ of the purified toxin or toxin fragments for $4 \mathrm{~h}$.

D HEp-2 cells treated with $500 \mathrm{nM}$ purified full-length CNFY, protein fragments D3-5 (CNFY 426-1014) or D4-5 (CNFY 526-1014) were lysed and the deamidation of RhoA was analyzed by the mobility shift of the modified GTPase detected by immunoblotting.

E The activity of purified CNFY and the protein fragments D3-5 (CNFY 426-1014) or D4-5 (CNFY 526-1014) was tested by analyzing the deamidation of RhoA in HEp-2 cell lysates by the mobility shift of the modified GTPase detected by immunoblotting. 


\section{Appendix tables and figures}

\section{Index}

\section{APPENDIX TABLES}

Table S1. Structural homology of domain D4.

Table S2. Domain Interfaces.

Table S3. Strains and plasmids.

Table S4. Oligonucleotide primers.

Figure S1. SDS-PAGE of purified $\mathrm{CNF}_{Y}$ fragments for crystallization.

Figure S2. Characterization of secretion, cell binding, and activity of the CNFY E382/383K variant. $\quad 7$

Figure S3. Translocation efficiency of full-length $\mathrm{CNF}_{Y}$ vs. $\mathrm{CNF}_{Y}$ 1-526.

Figure S4. Expression and analysis of CNFY D527-719 and $\mathrm{CNF}_{\mathrm{Y}}$ D527-699 deletion proteins missing domain D3.

Figure S5. Expression of $\mathrm{CNF}_{Y} \mathrm{E} 639$ and $639 \mathrm{Q}$ and in vitro deamidation of RhoA.

Figure S6. Binding of the CNFY D1-3 and D4-5 domain can be efficiently replaced by full-length $\mathrm{CNF}_{Y}, 11$ 


\section{Appendix Tables}

\section{Table S1. Domain Interfaces.}

The CNFY structural model was split at the domain boundaries and surfaces of the isolated domains and domaindomain interface areas were calculated using PDBe PISA (Krissinel \& Henrick, 2007).

\begin{tabular}{c|c|c|c|c}
\hline Domain & $\mathbf{1 - 4 2 5}$ & $\mathbf{4 2 6 - 5 2 6}$ & $\mathbf{5 2 7 - 7 0 0}$ & $\mathbf{7 1 8 - 1 0 1 4}$ \\
\hline Surface area & $19224 \AA^{2}$ & $5858 \AA^{2}$ & $9853 \AA^{2}$ & $12864 \AA^{2}$ \\
\hline $\mathbf{1 - 4 2 5}$ & - & $756 \AA^{2}$ & $1428 \AA^{2}$ & no contact \\
$\mathbf{4 2 6 - 5 2 6}$ & $756 \AA^{2}$ & - & $438 \AA^{2}$ & $611 \AA^{2}$ \\
$\mathbf{5 2 7 - 7 0 0}$ & $1428 \AA^{2}$ & $438 \AA^{2}$ & - & $385 \AA^{2}$ \\
$\mathbf{7 1 9 - 1 0 1 4}$ & no contact & $611 \AA^{2}$ & $385 \AA^{2}$ & - \\
\hline
\end{tabular}

Table S2. Structural homology of domain D4.

Structures with folds similar to domain D4 of CNFY as identified by DALI (Holm \& Rosenstrom, 2010). Listed below are the 10 highest scoring results, ordered according to their Z-score in descending order.

\begin{tabular}{l|l|l|l|l|l|l|l}
\hline PDB entry & Chain & $\begin{array}{l}\text { Z- } \\
\text { score }\end{array}$ & $\begin{array}{l}\mathbf{C}_{\alpha} \\
\mathbf{R} . \mathbf{m} . \mathbf{s . d} . \\
(\mathbf{A})\end{array}$ & $\begin{array}{l}\text { length of } \\
\text { alignment }\end{array}$ & $\begin{array}{l}\text { number of } \\
\text { residues in } \\
\text { target }\end{array}$ & $\begin{array}{l}\text { \% } \\
\text { sequence- } \\
\text { identity }\end{array}$ & Description \\
\hline 5LYH & $\mathrm{A}$ & 5.6 & 3.6 & 101 & 185 & 11 & $\begin{array}{l}\text { Human poly(ADP-ribose) } \\
\text { polymerase 14 }\end{array}$ \\
\hline 1WFX & $\mathrm{A}$ & 5.5 & 2.9 & 78 & 180 & 19 & $\begin{array}{l}\text { 2'-phosphotransferase from } \\
\text { Aeropyrum pernix }\end{array}$ \\
\hline 3HKV & $\mathrm{A}$ & 5.3 & 4.0 & 102 & 192 & 9 & $\begin{array}{l}\text { Human poly(ADP-ribose) } \\
\text { polymerase 10 }\end{array}$ \\
\hline 4F0D & $\mathrm{A}$ & 5.2 & 3.8 & 103 & 238 & 12 & $\begin{array}{l}\text { Human poly(ADP-ribose) } \\
\text { polymerase 16 }\end{array}$ \\
\hline 2Q5T & $\mathrm{A}$ & 5.2 & 4.1 & 100 & 605 & 11 & Cholix toxin from Vibrio cholerae \\
\hline 2AUA & $\mathrm{B}$ & 4.7 & 3.0 & 72 & 210 & 13 & $\begin{array}{l}\text { Protein of unknown function from } \\
\text { Bacillus cereus }\end{array}$ \\
\hline 1DDT & $\mathrm{A}$ & 4.7 & 3.6 & 94 & 523 & 12 & $\begin{array}{l}\text { Diphteria toxin from } \\
\text { Corynebacterium diphtheriae }\end{array}$ \\
\hline 4HYF & $\mathrm{A}$ & 4.5 & 4.7 & 101 & 227 & 10 & Human tankyrase-2 \\
\hline 4TLV & $\mathrm{A}$ & 4.4 & 4.9 & 89 & 582 & 11 & $\begin{array}{l}\text { CARDS toxin from Mycoplasma } \\
\text { pneumoniae }\end{array}$ \\
\hline 3AQ2 & $\mathrm{A}$ & 4.4 & 3.1 & 96 & 191 & 10 & $\begin{array}{l}\text { Protein 6b from Agrobacterium } \\
\text { vitis }\end{array}$ \\
\hline
\end{tabular}


bioRxiv preprint doi: https://doi.org/10.1101/2020.04.07.029181; this version posted September 21, 2020. The copyright holder for this preprint (which was not certified by peer review) is the author/funder, who has granted bioRxiv a license to display the preprint in perpetuity. It is made available under aCC-BY-NC-ND 4.0 International license.

Table S3: Strains and plasmids.

\begin{tabular}{|c|c|c|}
\hline Strain & Characteristics & Source/Reference \\
\hline YPIII & Wild type Yersinia pseudotuberculosis serogroup III & (Bolin, Norlander et al., 1982) \\
\hline YP147 & YPIII, $\Delta c n f Y:: \mathrm{Kn}^{\mathrm{R}}$ & (Schweer, Kulkarni et al., 2013) \\
\hline $\mathrm{DH} 10 \beta$ & & Invitrogen \\
\hline Rosetta II (DE3) & & Novagen \\
\hline BL21 (DE3) & & Novagen \\
\hline \multicolumn{3}{|l|}{ Plasmid } \\
\hline pFU189 & $\mathrm{Cm}^{\mathrm{R}}$ & (Uliczka \& Dersch, 2012) \\
\hline pTEM & $\mathrm{Cm}^{\mathrm{R}}$ & this study \\
\hline pCNF $F_{Y}-T E M$ & $\mathrm{Cm}^{\mathrm{R}}$ & this study \\
\hline pCNFYC866S-TEM & $\mathrm{Cm}^{\mathrm{R}}$ & this study \\
\hline pCNF$_{Y 1-719-T E M}$ & $\mathrm{Cm}^{\mathrm{R}}$ & this study \\
\hline pCNF $_{Y 1-526-T E M}$ & $\mathrm{Cm}^{\mathrm{R}}$ & this study \\
\hline $\mathrm{pCNF}_{\mathrm{Y} 1-443-\mathrm{TEM}}$ & $\mathrm{Cm}^{\mathrm{R}}$ & this study \\
\hline $\mathrm{pCNF}_{\mathrm{Y} \triangle 39-134-\mathrm{TEM}}$ & $\mathrm{Cm}^{\mathrm{R}}$ & this study \\
\hline pCNF$_{Y \Delta 134-426-T E M}$ & $\mathrm{Cm}^{\mathrm{R}}$ & this study \\
\hline pCNFY ${ }_{Y 39-426-T E M}$ & $\mathrm{Cm}^{\mathrm{R}}$ & this study \\
\hline pCNFY ${ }_{Y 527-719-T E M}$ & $\mathrm{Cm}^{\mathrm{R}}$ & this study \\
\hline $\mathrm{pCNF}_{\mathrm{Y} \Delta 527-699-\mathrm{TEM}}$ & $\mathrm{Cm}^{\mathrm{R}}$ & this study \\
\hline pCNFYE382/383к-TEM & $\mathrm{Cm}^{\mathrm{R}}$ & this study \\
\hline p3xFLAG & $\mathrm{Cm}^{\mathrm{R}}$ & this study \\
\hline pCNFY-3xFLAG & $\mathrm{Cm}^{\mathrm{R}}$ & this study \\
\hline $\mathrm{pCNF}_{\mathrm{YC} 866 \mathrm{~S}}-3 \mathrm{xFLAG}$ & $\mathrm{Cm}^{\mathrm{R}}$ & this study \\
\hline $\mathrm{pCNF}_{Y 1-719-3 x F L A G}$ & $\mathrm{Cm}^{\mathrm{R}}$ & this study \\
\hline pCNF$_{Y 1-526-3 x F L A G}$ & $\mathrm{Cm}^{\mathrm{R}}$ & this study \\
\hline $\mathrm{pCNF}_{\mathrm{Y1}-443-3 x \mathrm{FLAG}}$ & $\mathrm{Cm}^{\mathrm{R}}$ & this study \\
\hline pCNF $_{Y \Delta 39-134-3 x F L A G}$ & $\mathrm{Cm}^{\mathrm{R}}$ & this study \\
\hline $\mathrm{pCNF}_{Y \Delta 134-426^{-}-3 x F L A G}$ & $\mathrm{Cm}^{\mathrm{R}}$ & this study \\
\hline $\mathrm{pCNF}_{\mathrm{Y} \triangle 39-426-3 x \mathrm{FLAG}}$ & $\mathrm{Cm}^{\mathrm{R}}$ & this study \\
\hline $\mathrm{pCNF}_{Y \Delta 527-719-3 x F L A G}$ & $\mathrm{Cm}^{\mathrm{R}}$ & this study \\
\hline $\mathrm{pCNF}_{Y \Delta 527-699-3 x F L A G}$ & $\mathrm{Cm}^{\mathrm{R}}$ & this study \\
\hline pCNFFE382/383K-3xFLAG & $\mathrm{Cm}^{\mathrm{R}}$ & this study \\
\hline pCNFY I535L/P536A/V537G-TEM & $\mathrm{Cm}^{\mathrm{R}}$ & this study \\
\hline 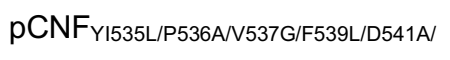 & $\mathrm{Cm}^{\mathrm{R}}$ & this study \\
\hline \multicolumn{3}{|l|}{ K542A-TEM } \\
\hline pCNFY-GFP & $\mathrm{Cm}^{\mathrm{R}}$ & this study \\
\hline $\mathrm{pCNF}_{\mathrm{Y1-719}-\mathrm{GFP}}$ & $\mathrm{Cm}^{\mathrm{R}}$ & this study \\
\hline $\mathrm{pCNF}_{\mathrm{Y} 1-526}-\mathrm{GFP}$ & $\mathrm{Cm}^{\mathrm{R}}$ & this study \\
\hline $\mathrm{pCNF}_{Y 1-443-\mathrm{GFP}}$ & $\mathrm{Cm}^{\mathrm{R}}$ & this study \\
\hline pCOLA-Duet-1 & $\mathrm{Kan}^{\mathrm{R}}$ & Novagen \\
\hline pET28c-CNF $1-704$ & $\mathrm{Kan}^{\mathrm{R}}$ - construct for crystallography purposes & this study \\
\hline pET28c-CNFY720-1014 & $\mathrm{Kan}^{\mathrm{R}}$ - construct for crystallography purposes & this study \\
\hline pVP-CNFY526-1014-3xFlag & $\mathrm{Kan}^{\mathrm{R}}$ - construct for crystallography purposes & this study \\
\hline pVP-CNFYFL-C866S & $\mathrm{Kan}^{\mathrm{R}}$ - construct for crystallography purposes & this study \\
\hline
\end{tabular}


Table S4: Oligonucleotide primers.

\begin{tabular}{|c|c|c|}
\hline Primer & ence 5'-3' & \\
\hline blaM F & GGCCTGCAGGCCACCCAGAAACGCTGGTGAA & blaM cloning into pFU189 Pstl \\
\hline blaM R & $\begin{array}{l}\text { GTTGCGGCCGCTTTACCAATGCTTAATCAGTGAGG } \\
\text { CA }\end{array}$ & blaM cloning into pFU189 Notl \\
\hline $3 x F l a g F$ & $\begin{array}{l}\text { GGTGGTGACTACAAGGACCACGACGGCGATTATAA } \\
\text { GGATCACGATATCGATTACAAGGACGATGACGACA } \\
\text { AGTGAAGC }\end{array}$ & 3xFlag cloning into pFU189 \\
\hline 3xFlagR & $\begin{array}{l}\text { GGCCGCTTCACTTGTCGTCATCGTCCTTGTAATCG } \\
\text { ATATCGTGATCCTTATAATCGCCGTCGTGGTCCTTG } \\
\text { TAGTCACCACCTGCA }\end{array}$ & 3xFlag cloning into pFU189 \\
\hline VI532 & GACTGCAGATTCTGTGAGAAATC & cnfY aa1-719 rev Pstl \\
\hline VI533 & GACTGCAGACTGACCACCTTT & $c n f Y$ aa $1-526$ rev $P s t l$ \\
\hline VI958 & $\begin{array}{l}\text { CGTGCAAAAACAACTGTACTCCCTGTTAAAGTACCA } \\
\text { GAG }\end{array}$ & cnfY SDM C866S fwd \\
\hline VI959 & $\begin{array}{l}\text { CTCTGGTACTTTAACAGGGAGTACAGTTGTTTTTTGC } \\
\text { ACG }\end{array}$ & cnfY SDM C866S rev \\
\hline VII006 & $\begin{array}{l}\text { TATCACCTGCAGGAATATTGTACTTTTCCAAAAAAT } \\
\text { C }\end{array}$ & cnfY 1-443 rev Pstl \\
\hline VII006 & $\begin{array}{l}\text { TATCACCTGCAGGAATATTGTACTTTTCCAAAAAAT } \\
\text { C }\end{array}$ & cnfY 1-443 rev Pstl \\
\hline VII061 & AAGTTTAGTACAACAGATTTTTCTAATCTC & $c n f Y 39-134$ deletion fwd \\
\hline VII062 & GAGATTAGAAAAATCTGTTGTACTAAACTT & cnfY 39-134 deletion rev \\
\hline VII063 & TATTTTTTGAGAGATAACATACTTAATAAA & $c n f Y 134-426$ deletion fwd \\
\hline VII064 & TTTATTAAGTATGTTATCTCTCAAAAAATA & $c n f Y 134-426$ deletion rev \\
\hline VII065 & AAGTTTAGTACAACAAACATACTTAATAAA & cnf $Y 39-426$ deletion fwd \\
\hline VII066 & TTTATTAAGTATGTTTGTTGTACTAAACTT & $c n f Y 39-426$ deletion rev \\
\hline VII066 & TTTATTAAGTATGTTTGTTGTACTAAACTT & cnfY $39-426$ deletion rev \\
\hline VII765 & CTGAAAGGTGGTCAGAACGTAGCTGAAATT & cnfY 527-719 deletion fwd \\
\hline VII766 & AATTTCAGCTACGTTCTGACCACCTTTCAG & cnfY 527-719 deletion rev \\
\hline VII849 & CTGAAAGGTGGTCAGCCACCAGTAAAACCA & cnfY 527-699 deletion fwd \\
\hline VII850 & TGGTTTTACTGGTGGCTGACCACCTTTCAG & cnfY 527-699 deletion rev \\
\hline VIIII261 & $\begin{array}{l}\text { GATGAGTTAATAAACGGGGATACTTATAAAAAGCGT } \\
\text { CGCTCTGCA }\end{array}$ & cnfY SDM E382/383K fwd \\
\hline VIII262 & $\begin{array}{l}\text { TGCAGAGCGACGCTTTTTTATAAGTATCCCCGTTTAT } \\
\text { TAACTCATC }\end{array}$ & $c n f Y$ SDM E382/383K rev \\
\hline VIIII263 & $\begin{array}{l}\text { CAGCCATTTAACTTCGAGGGGCTTGATCTTGCTGG } \\
\text { TTATTTTATAGATAAACCATATTCTGAA }\end{array}$ & cnfY SDM 1535L/P536A/V537G fwd \\
\hline VIIII264 & $\begin{array}{l}\text { TTCAGAATATGGTTTATCTATAAAATAACCAGCAAG } \\
\text { ATCAAGCCCCTCGAAGTTAAATGGCTG }\end{array}$ & cnfY SDM I535L/P536A/V537G rev \\
\hline VIIII265 & $\begin{array}{l}\text { AACTTCGAGGGGCTTGATCTTGCTGGTTATTTAATA } \\
\text { GCTGCACCATATTCTGAACTTGCATC }\end{array}$ & cnfY SDM F539L/D541A/K542A fwd \\
\hline VIIII266 & $\begin{array}{l}\text { GATGCAAGTTCAGAATATGGTGCAGCTATTAAATAA } \\
\text { CCAGCAAGATCAAGCCCCTCGAAGTT }\end{array}$ & cnfY SDM F539L/D541A/K542A rev \\
\hline FL_f_Notl & $\begin{array}{l}\text { AAGAATGCGGCCGCATGAAAAATCAATGGCAACAT } \\
\text { C }\end{array}$ & $\begin{array}{l}\text { cnfY 1-1014 forward Notl for cloning into } \\
\text { modified pCOLA Duet-1 }\end{array}$ \\
\hline FL_r_Kpnl & $\begin{array}{l}\text { GGGGTACCTTAAAAGTCTTTTTGTAAAACATTAAAC } \\
\text { ACAACC }\end{array}$ & $\begin{array}{l}\text { cnfY } 1-1014 \text { reverse Kpnl for cloning into } \\
\text { modified pCOLA Duet-1 }\end{array}$ \\
\hline 526_f_Notl & AAGAATGCGGCCGCCAGCCATTTAACTTCG & $\begin{array}{l}\text { cnfY 526-1014 forward Notl for cloning into } \\
\text { modified pCOLA Duet-1 }\end{array}$ \\
\hline Flag3_r_Kpnl & GGGGTACCTCACTTGTCGTCATCGTC & $\begin{array}{l}\text { cnfY 526-1014 } 3 \times \text { Flag reverse } K p n l \text { for } \\
\text { cloning into modified pCOLADuet-1 }\end{array}$ \\
\hline
\end{tabular}


bioRxiv preprint doi: https://doi.org/10.1101/2020.04.07.029181; this version posted September 21, 2020. The copyright holder for this preprint (which was not certified by peer review) is the author/funder, who has granted bioRxiv a license to display the preprint in perpetuity. It is made available under aCC-BY-NC-ND 4.0 International license.

\begin{tabular}{|c|c|c|}
\hline GGS_TEM_F & $\begin{array}{l}\text { GGCGGTAGCGGTGGCAGCCCAGAAACGCTGGTGA } \\
\text { AA }\end{array}$ & Amplifcation of TEM gene, forward primer \\
\hline GGS_Notl_F & $\begin{array}{l}\text { AAGAATGCGGCCGCTCCGGAGGCGGTAGCGGTGG } \\
\text { CAGC }\end{array}$ & TEM forward Notl primer \\
\hline $\begin{array}{l}\text { TEM_pVP008_ } \\
\text { R }\end{array}$ & GAGAATGGTACCTTACCAATGCTTAATCAGTG & Amplifcation of TEM gene, reverse primer \\
\hline $\begin{array}{l}\text { CNFy1_pVP008 } \\
\text { Notl_F }\end{array}$ & $\begin{array}{l}\text { TCCAGGGAGGCGGCCGCATGAAAAATCAATGGCAA } \\
\text { CATC }\end{array}$ & $\begin{array}{l}\text { cnfY 1-1014 forward Notl for cloning into } \\
\text { pVP008 intermediate plasmid }\end{array}$ \\
\hline $\begin{array}{l}\text { CNFy526_TEM_ } \\
\text { BspEI_R }\end{array}$ & $\begin{array}{l}\text { CGCTACCGCCTCCGGACTGACCACCTTTCAGTCCT } \\
\text { C }\end{array}$ & $\begin{array}{l}\text { cnfY } 1-526 \text { reverse } B s p E 1 \text { for cloning into } \\
\text { pVP008 intermediate plasmid }\end{array}$ \\
\hline $\begin{array}{l}\text { CNFy1014_TEM } \\
\text { BspEl_R }\end{array}$ & $\begin{array}{l}\text { CGCTACCGCCTCCGGAAAAGTCTTTTTTGTAAAACAT } \\
\text { T }\end{array}$ & $\begin{array}{l}\text { cnfY 1-1014 reverse } B s p E 1 \text { for cloning into } \\
\text { pVP008 intermediate plasmid }\end{array}$ \\
\hline CNFy1_pET28a & CGCGCGGCAGCCATATGATGAAAAATCAATGGCAA & $\begin{array}{l}\text { cnfY 1-1014 forward Nde1 for cloning into } \\
\text { pET28a }\end{array}$ \\
\hline $\begin{array}{l}\text { TEM_pET28a_H } \\
\text { indllI_R }\end{array}$ & $\begin{array}{l}\text { GTGCGGCCGCAAGCTTTTACCAATGCTTAATCAGT } \\
\text { GAGG }\end{array}$ & TEM reverse Hindlll for cloning into $\mathrm{pET} 28 \mathrm{a}$ \\
\hline
\end{tabular}




\section{Appendix Figures}

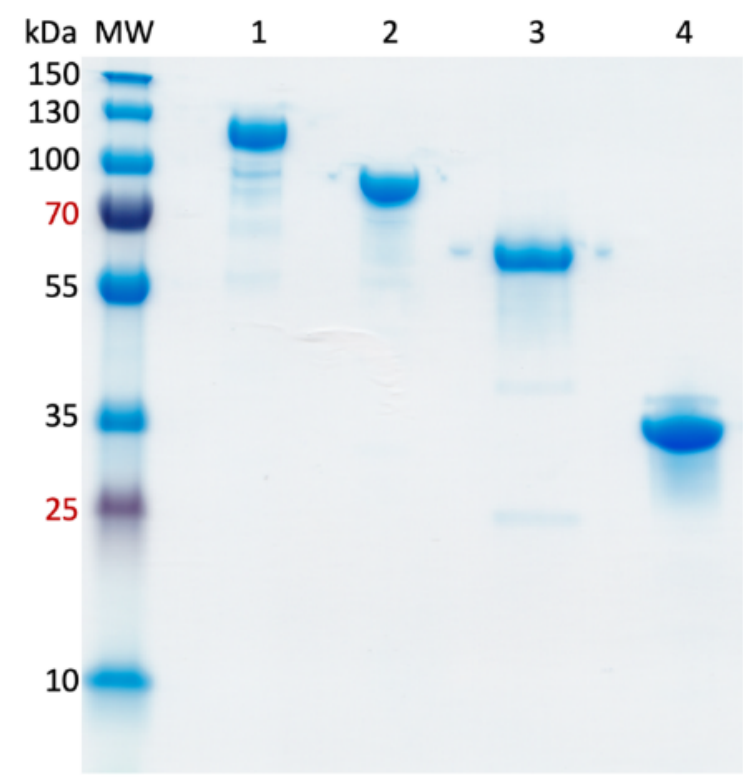

Figure S1. SDS-PAGE of purified $\mathrm{CNF}_{\mathrm{Y}}$ fragments for crystallization

Coomassie-stained SDS-PAGE (Any kD Mini-PROTEAN TGX, Bio-Rad). The fragments have been produced in $E$. coli and were purified as described in the methods section. MW: Molecular weight standard (PageRuler Plus prestained ladder, Thermo), 1: CNFY full-length, 2: CNFY 1-704, 3: CNFY 526-1014, 4: CNFY 720-1014. $2 \mu \mathrm{g}$ of each construct have been loaded onto the gel. 
A

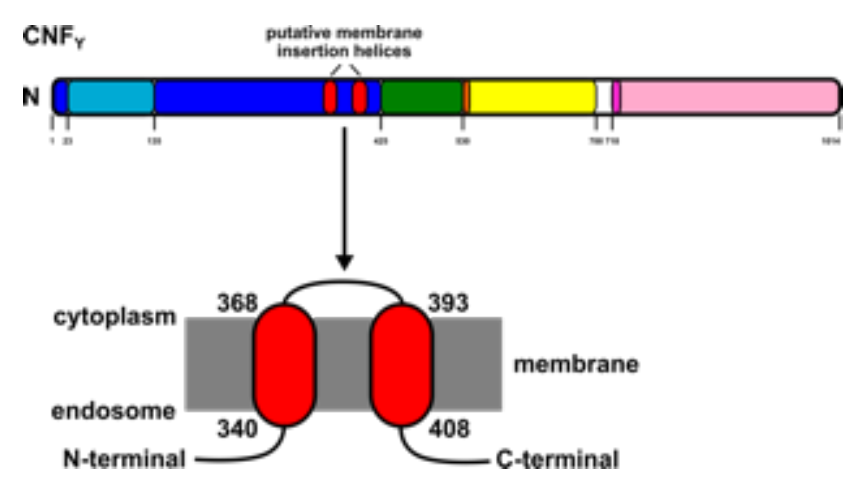

B

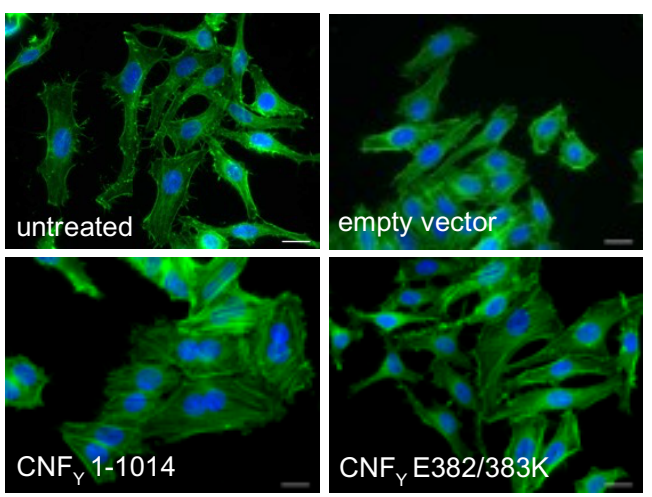

C

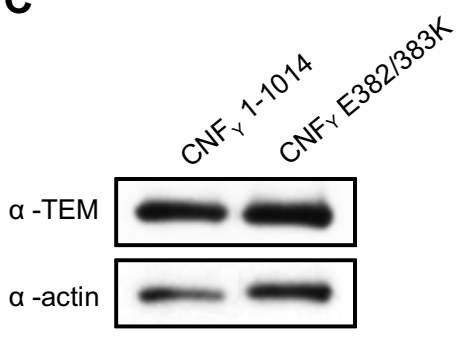

$\mathbf{F}$

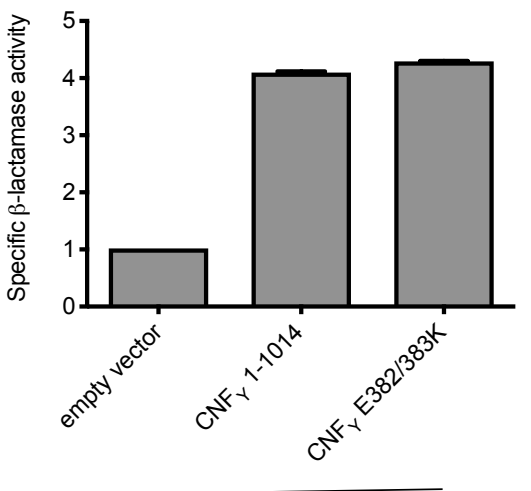

YP147( $(\Delta c n f Y)$
D

a-RhoA

a-actin

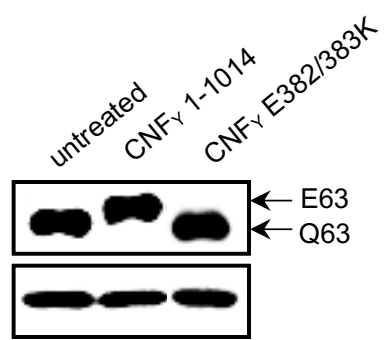

$\mathbf{E}$

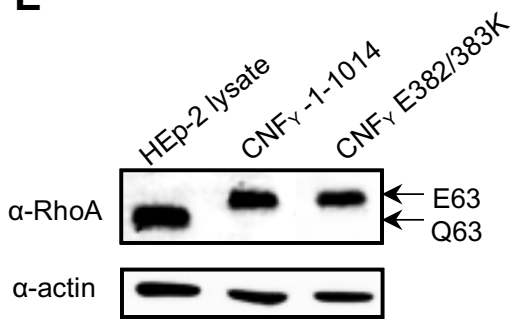

G

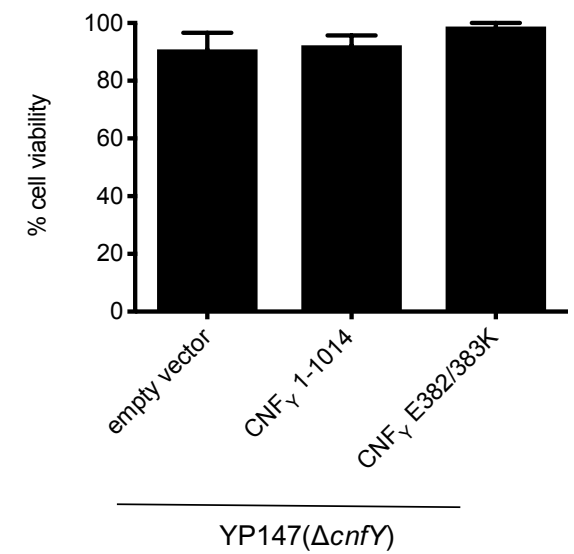

Figure S2. Characterization of secretion, cell binding, and activity of the $\mathrm{CNF}_{\mathrm{Y}} \mathrm{E} 382 / 383 \mathrm{~K}$ variant.

A A schematic overview of CNFY illustrating the predicted helical regions of the $\mathrm{D} 2$ domain exposing the acidic loop. B HEp-2 cells were incubated with $20 \mu \mathrm{g} / \mathrm{ml}$ of whole cell extract of $Y$. pseudotuberculosis expressing CNFY, the toxin variant $\mathrm{CNFY}_{\mathrm{Y}} \mathrm{E} 382 / 383 \mathrm{~K}$ or no $\mathrm{CNFY}_{\mathrm{Y}}$ protein (harboring empty vector) for $24 \mathrm{~h}$. The formation of large, multinuclear cells was observed by fluorescence microscopy. The cell nuclei were strained with DAPI (blue) and the actin cytoskeleton was stained using FITC-Phalloidin (green). The white scale bar is $20 \mu \mathrm{m}$.

C The binding of CNFY to HEp-2 cells was analyzed by immunoblotting after HEp-2 cells were incubated with 20 $\mu \mathrm{g} / \mathrm{ml}$ of whole cell extract of $Y$. pseudotuberculosis expressing $\mathrm{CNF}_{\mathrm{Y}}$ for $4 \mathrm{~h}$.

D Cells incubated with $20 \mu \mathrm{g} / \mathrm{ml}$ of whole cell extract of $Y$. pseudotuberculosis expressing CNFY and the toxin variant CNFY E382/383K for $4 \mathrm{~h}$ were lysed and the deamidation of RhoA was analyzed by the mobility shift of the modified GTPase detected by immunoblotting.

$\mathrm{E}$ The activity of the purified $\mathrm{CNFY}_{\mathrm{Y}}$ derivatives was tested by analyzing the deamidation of RhoA in HEp-2 cell lysates by the mobility shift of the modified GTPase detected by immunoblotting.

$\mathrm{F}$ CNFY-TEM and CNFY E382/383-TEM secretion was determined by measuring changes in absorbance of nitrocefin at $390 \mathrm{~nm}$ (yellow) and $486 \mathrm{~nm}$ (red).

G The microbial viability of the bacteria expressing $C N F_{Y}$ and $C N F_{Y} E 382 / 383$ was assessed in equalized bacterial cultures using the BacTiter-Glo ${ }^{\mathrm{TM}}$ Microbial Cell Viability Assay kit. 
A

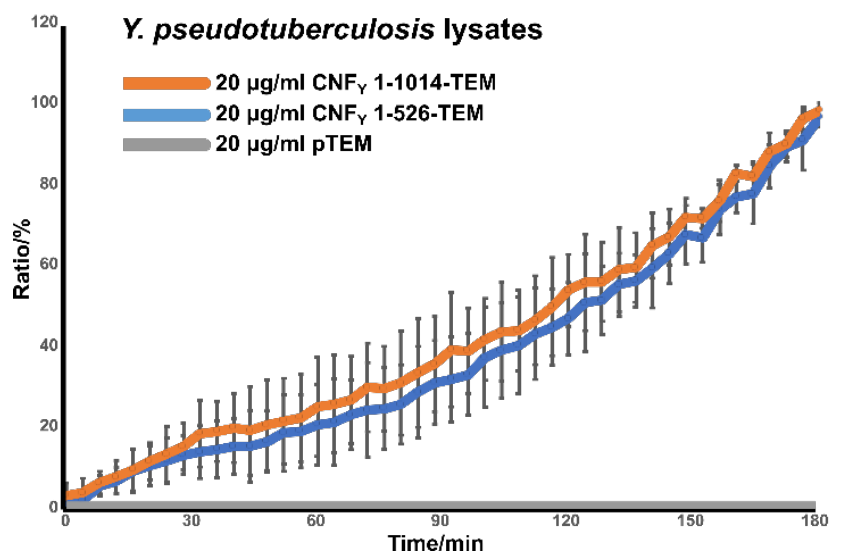

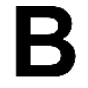

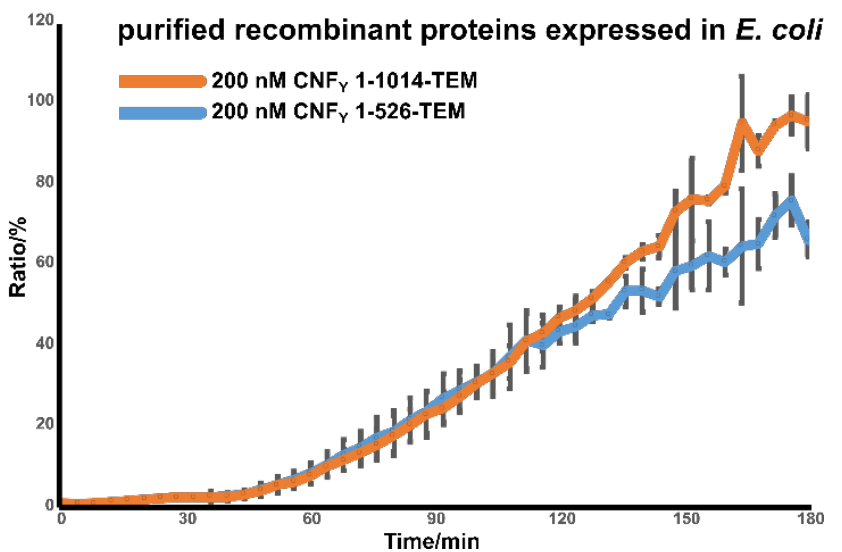

Figure S3. Translocation efficiency of full-length $C_{\text {NFY }}$ vs. CNFY 1-526

HEp-2 cells were loaded with CCP4-AM and then incubated with the indicated CNFY-TEM fusion proteins applied either as (A) lysates from $Y$. pseudotuberculosis or as (B) purified recombinant proteins purified from $E$. coli. The development of blue fluorescence, indicating translocation of TEM- $\beta$-lactamase into the cytosol, is plotted for $3 \mathrm{~h}$, taking the final reading as $100 \%$. Error bars represent standard deviations of $(A)$ eight or $(B)$ three replicates. Lysate from $Y$. pseudotuberculosis harboring just the pTEM plasmid served as a negative control and demonstrates that TEM- $\beta$-lactamase cannot enter HEp-2 cells when it is not fused to the translocation machinery (A). 
A

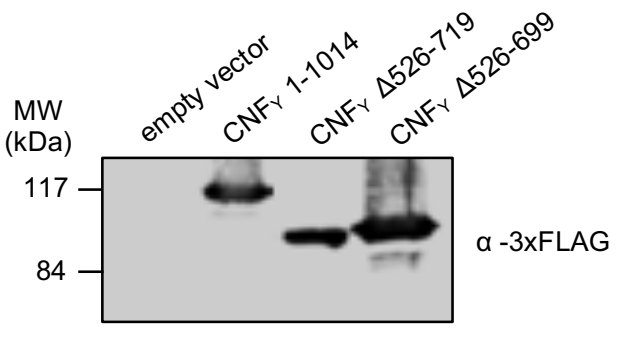

B

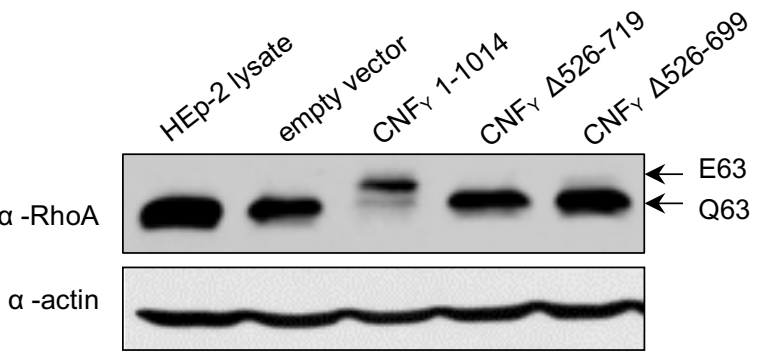

Figure S4. Expression and analysis of $\mathrm{CNF}_{\mathrm{Y}} \Delta$ 527-719 or $\mathrm{CNF}_{\mathrm{Y}} \Delta 527-699$ deletion proteins missing domain D3.

A Expression of 3XFlag-lagged version of $\mathrm{CNF}_{Y}$ wildtype protein (CNFY1-1014 aa) and the internal deletion derivatives $C N F_{Y} \Delta 526-699$ and $C N F_{Y} \Delta 526-719$.

B HEp-2 cell lysates were incubated with $20 \mu \mathrm{g} / \mathrm{ml}$ of whole cell extract of $Y$. pseudotuberculosis expressing the indicated CNFY protein and their activity was tested by analyzing the deamidation of RhoA in HEp-2 cell lysates by the mobility shift of the modified GTPase detected by immunoblotting. 
A
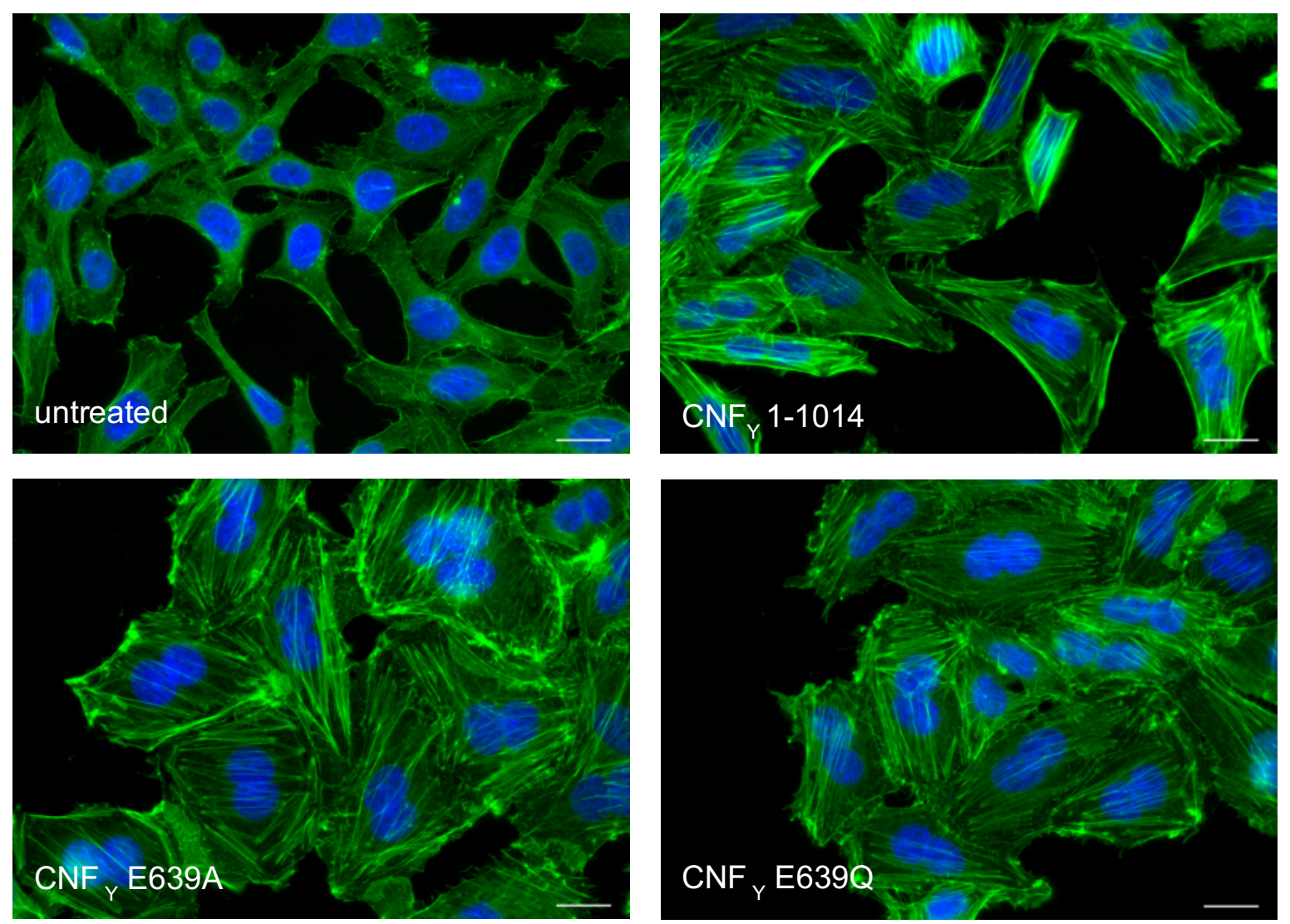

B
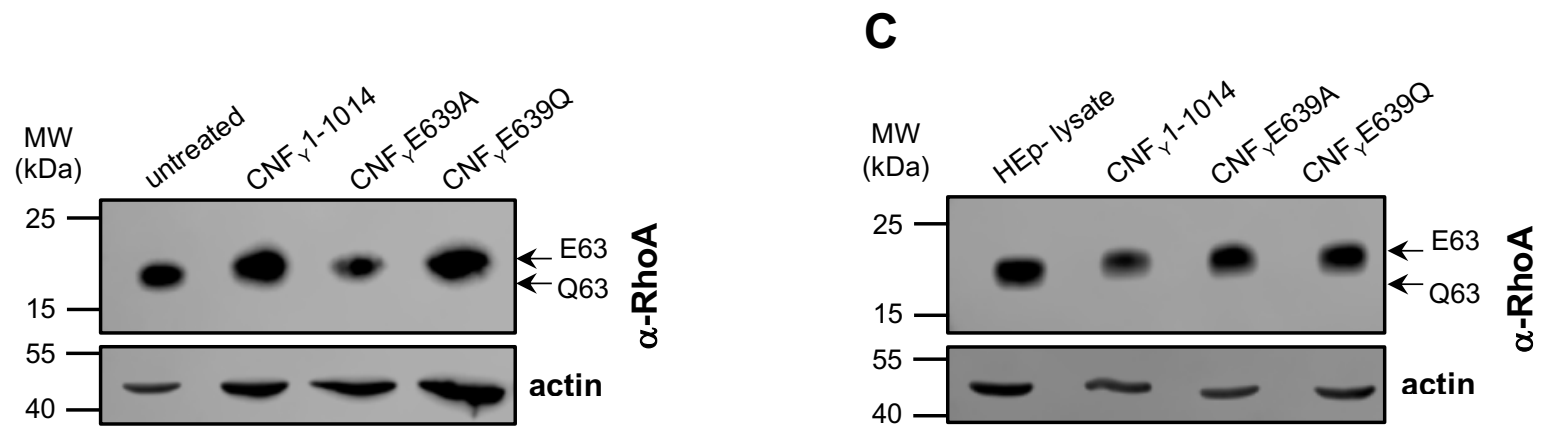

Figure S5. Expression of CNFY E639A and 639Q and in vitro deamidation of RhoA.

A Purified CNFY E639A and 639Q proteins ( $500 \mathrm{nM}$ ) were added to HEp-2 cells for $24 \mathrm{~h}$. Cell nuclei were strained with DAPI (blue) and the actin cytoskeleton was stained using FITC-phalloidin (green) after treatment of cells with CNFY toxins and cells assessed by microscopy. The white scale bar is $20 \mu \mathrm{m}$.

B HEp-2 cells treated with $500 \mathrm{nM}$ purified full-length $\mathrm{CNF}_{Y}, \mathrm{CNF}_{Y} \mathrm{CNF}_{Y} \mathrm{E} 639 \mathrm{~A}$ and $639 \mathrm{Q}$ were lysed and the deamidation of RhoA was analyzed by the mobility shift of the modified GTPase detected by immunoblotting.

$\mathrm{C}$ The activity of the CNFY mutant proteins were tested by analyzing the deamidation of RhoA in HEp-2 cell lysates by the mobility shift of the modified GTPase detected by immunoblotting. 

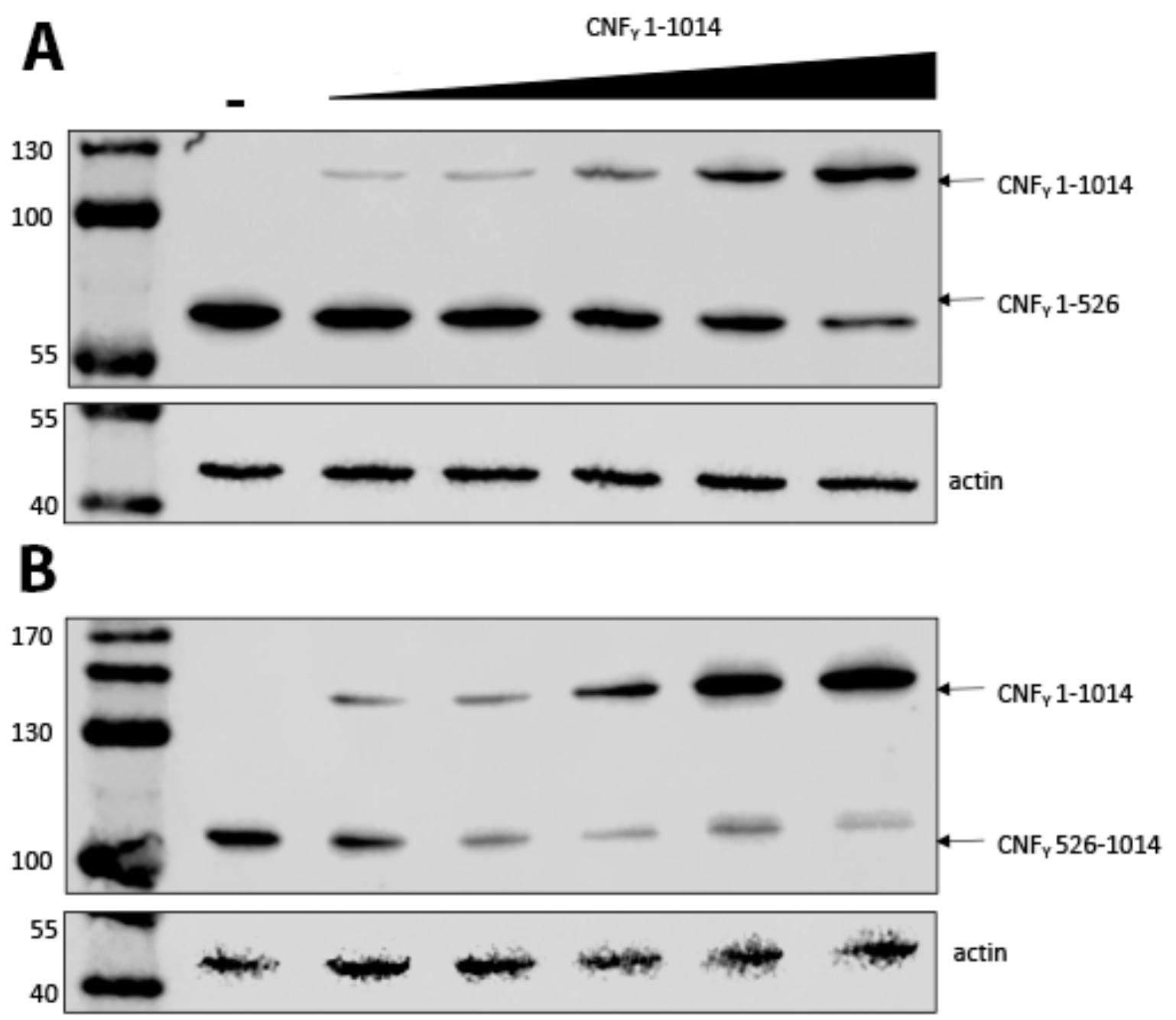

Fig. S6: Binding of the CNFY D1-3 and D4-5 domain can be efficiently replaced by full-length CNFY.

HEp-2 cells were incubated with $25 \mu \mathrm{g} / \mathrm{ml}$ of 3xFlag-tagged CNFY 1-526 (A) or CNFY 526-1014 (B) and no (-) or increasing amounts of the full-length 3x-Flag-tagged CNFy protein $(25,50,100,250$, and $500 \mu \mathrm{g} / \mathrm{ml}$ bacterial extract of bacteria overexpressing the toxin derivatives) at $4^{\circ} \mathrm{C}$ for $1 \mathrm{~h}$. Subsequently, whole cell extracts were prepared and bound CNFy proteins were detected by Western blotting using a monoclonal anti-FLAG antibody. 


\section{Appendix References}

Bolin I, Norlander L, Wolf-Watz H (1982) Temperature-inducible outer membrane protein of Yersinia pseudotuberculosis and Yersinia enterocolitica is associated with the virulence plasmid. Infect Immun 37: 506-12.

Holm L, Rosenstrom P (2010) Dali server: conservation mapping in 3D. Nucleic Acids Res 38: W545-9

Karplus PA, Diederichs K (2012) Linking crystallographic model and data quality. Science 336: 1030-3

Krissinel E, Henrick K (2007) Inference of macromolecular assemblies from crystalline state. Journal of molecular biology 372: 774-97

Larkin MA, Blackshields G, Brown NP, Chenna R, McGettigan PA, McWilliam H, Valentin F, Wallace IM, Wilm A, Lopez R, Thompson JD, Gibson TJ, Higgins DG (2007) Clustal W and Clustal X version 2.0. Bioinformatics 23: 2947-8

Robert X, Gouet P (2014) Deciphering key features in protein structures with the new ENDscript server. Nucleic Acids Research, 42: W320-W324.

Schweer J, Kulkarni D, Kochut A, Pezoldt J, Pisano F, Pils MC, Genth H, Huehn J, Dersch P (2013) The cytotoxic necrotizing factor of Yersinia pseudotuberculosis $\left(\mathrm{CNF}_{\mathrm{Y}}\right)$ enhances inflammation and Yop delivery during infection by activation of Rho GTPases. PLoS Pathogens 9: e1003746

Uliczka F, Dersch P (2012) Unique virulence properties of Yersinia enterocolitica O:3. Adv Exp Med Biol 954: $281-7$ 